\title{
Synthesis and NMR spectroscopy of nine stereoisomeric 5,7-diacetamido-3,5,7,9-tetradeoxynon-2-ulosonic acids
}

\author{
Yury E. Tsvetkov, ${ }^{\mathrm{a}, *}$ Alexander S. Shashkov, ${ }^{\mathrm{a}}$ Yuriy A. Knirel, ${ }^{\mathrm{a}}$ Ulrich Zähringerb \\ ${ }^{a}$ N.D. Zelinsky Institute of Organic Chemistry, Russian Academy of Sciences, Leninsky Prospeckt 47, \\ 119991 Moscow, Russian Federation \\ ${ }^{\mathrm{b}}$ Forschungszentrum Borstel, Zentrum für Medizin und Biowissenschaften, Parkallee 22, D-23845 Borstel, Germany
}

Received 28 June 2001; accepted 15 August 2001

\begin{abstract}
Derivatives of 5,7-diamino-3,5,7,9-tetradeoxynon-2-ulosonic acids are essential constituents of some bacterial polysaccharides and glycoproteins. In order to establish reliably the configuration of the natural sugars, nine stereoisomeric 5,7-diacetamido-3,5,7,9-tetradeoxynon-2-ulosonic acids were synthesized, including di- $N$-acetyl-legionaminic and -pseudaminic acids (the D-glycero-D-galacto and L-glycero-L-manno isomers, respectively) and their isomers at C-4, C-5, C-7, and C-8 having the L-glycero-D-galacto, D-glycero-D-talo, L-glycero-D-talo, D-glycero-L-altro, L-glycero-L-altro, D-glycero-L-manno, and L-glycero-L-gluco configurations. Synthesis was performed by condensation of 2,4-diacetamido-2,4,6-trideoxy-L-gulose, -D-mannose, -D-talose, and -L-allose with oxalacetic acid under basic conditions, the reaction of the last two precursors being accompanied by epimerisation at $\mathrm{C}-2$. The ${ }^{1} \mathrm{H}$ and ${ }^{13} \mathrm{C}$ NMR data of the synthetic compounds are discussed. Acetylated methyl esters of the C-7 and C-8 isomeric nonulosonic acids were prepared and used for analysis of the side-chain conformation by NMR spectroscopy. (C) 2001 Published by Elsevier Science Ltd.
\end{abstract}

Keywords: 5,7-Diacetamido-3,5,7,9-tetradeoxynon-2-ulosonic acids, synthesis; 2,4-Diacetamido-2,4,6-trideoxyhexoses; Legionaminic acid; Pseudaminic acid; Lipopolysaccharide components

\section{Introduction}

$\mathrm{N}$-Acyl and $O$-acetyl derivatives of various 5,7-diamino-3,5,7,9-tetradeoxynon-2-ulosonic acids are known as components of glycopolymers of Gram-negative bacteria, including lipopolysaccharides, ${ }^{1-3}$ a capsular polysaccharide, ${ }^{4}$ and glycoproteins. ${ }^{5,6}$ They play a role in immunospecificity, endow the cell surface with

* Corresponding author. Tel.: + 7-95-9383686; fax: + 795-1355328.

E-mail address: tsvetkov@ioc.ac.ru (Y.E. Tsvetkov). peculiar physicochemical properties, and are likely involved in bacterial virulence. Whereas the relative configuration within the conformationally rigid pyranose ring $(\mathrm{C}-4,5,6)$ of the higher sugars could be easily established using ${ }^{1} \mathrm{H}$ NMR and NOE spectroscopy, reliable determination of the configuration in the flexible side chain $(\mathrm{C}-7,8)$ required data from model compounds. To solve this problem, we synthesised, for the first time, nine stereoisomeric 5,7-diacetamido-3,5,7,9-tetradeoxynon-2-ulosonic acids. Synthesis of four of these sugars has been reported in preliminary communications. ${ }^{7,8}$ 


\section{Results and discussion}

By analogy with the synthesis of $N$-acetylneuraminic acid, ${ }^{9}$ di- $N$-acetyl derivatives of 5,7-diamino-3,5,7,9-tetradeoxynon-2-ulosonic acids could be obtained by condensation of 2,4-diacetamido-2,4,6-trideoxyhexoses with oxalacetic acid under basic conditions. Four chiral centers in the $\mathrm{C}_{6}$ precursors, $\mathrm{C}-2,3,4,5$, correspond to the centers $\mathrm{C}-5,6,7,8$ in the target $\mathrm{C}_{9}$ acids, and the fifth asymmetric center, $\mathrm{C}-4$, is formed on condensation. 2,4-Diacetamido-2,4,6-trideoxy-L-gulose (15), -Dtalose (25), -D-mannose (32), and -L-allose (48) were used as the $\mathrm{C}_{6}$ precursors (See Schemes 1-4). They possess the same, L,L configuration at C-2 and C-3 (C-5 and C-6 in the expected $\mathrm{C}_{9}$ acids), whereas the configurations at C-4 and C-5 vary, thus adopting all possible stereochemical combinations at C-7 and $\mathrm{C}-8$ in the higher sugars $(\mathrm{D}, \mathrm{L} ; \mathrm{L}, \mathrm{D} ; \mathrm{D}, \mathrm{D}$; and $\mathrm{L}, \mathrm{L}$; respectively).

The 2,4-diacetamido-2,4,6-trideoxyhexoses $\mathbf{1 5}, \mathbf{2 5}, 32$, and 48 were synthesized as follows. L-Rhamnose, the most readily available 6-deoxyhexose, served as the progenitor of $\mathbf{1 5}$.
Since introduction of an azido group (as a precursor of the acetamido function) is accompanied by inversion of the configuration, azidation at positions 2 and 4 would lead directly to the desirable configurations of C-2 and $\mathrm{C}-4$. Hence, one additional inversion at C-3 has to be performed to achieve the target L-gulo configuration.

The prerequisite for successful $\mathrm{S}_{\mathrm{N}} 2$ substitution of an axial sulfonate group at C-2 is that the substituent at C-1 is equatorial (see Ref. ${ }^{10}$ and references cited therein). Therefore, benzyl $\beta$-L-rhamnopyranoside was thought to be the precursor of choice. This was prepared by $\mathrm{Bu}_{2} \mathrm{SnO}$-mediated benzylation of 1,2-diol $\mathbf{1}^{11}$ (Scheme 1). As expected, ${ }^{12}$ the reaction occurred in a regio- and stereoselective manner, though it was accompanied by migration of benzoyl protecting groups. As a result, a mixture of benzyl $\beta$-rhamnopyranoside dibenzoates 2-4 was obtained in total yield of $90-95 \%$ and $2: 3: 4$ ratios of $\sim 4: 3: 1$. These compounds were separated and their structures proved by ${ }^{1} \mathrm{H}$ NMR spectroscopy. Most importantly, the $\beta$-configuration of $\mathbf{2}-\mathbf{4}$ was demonstrated by a relatively high-field posi-
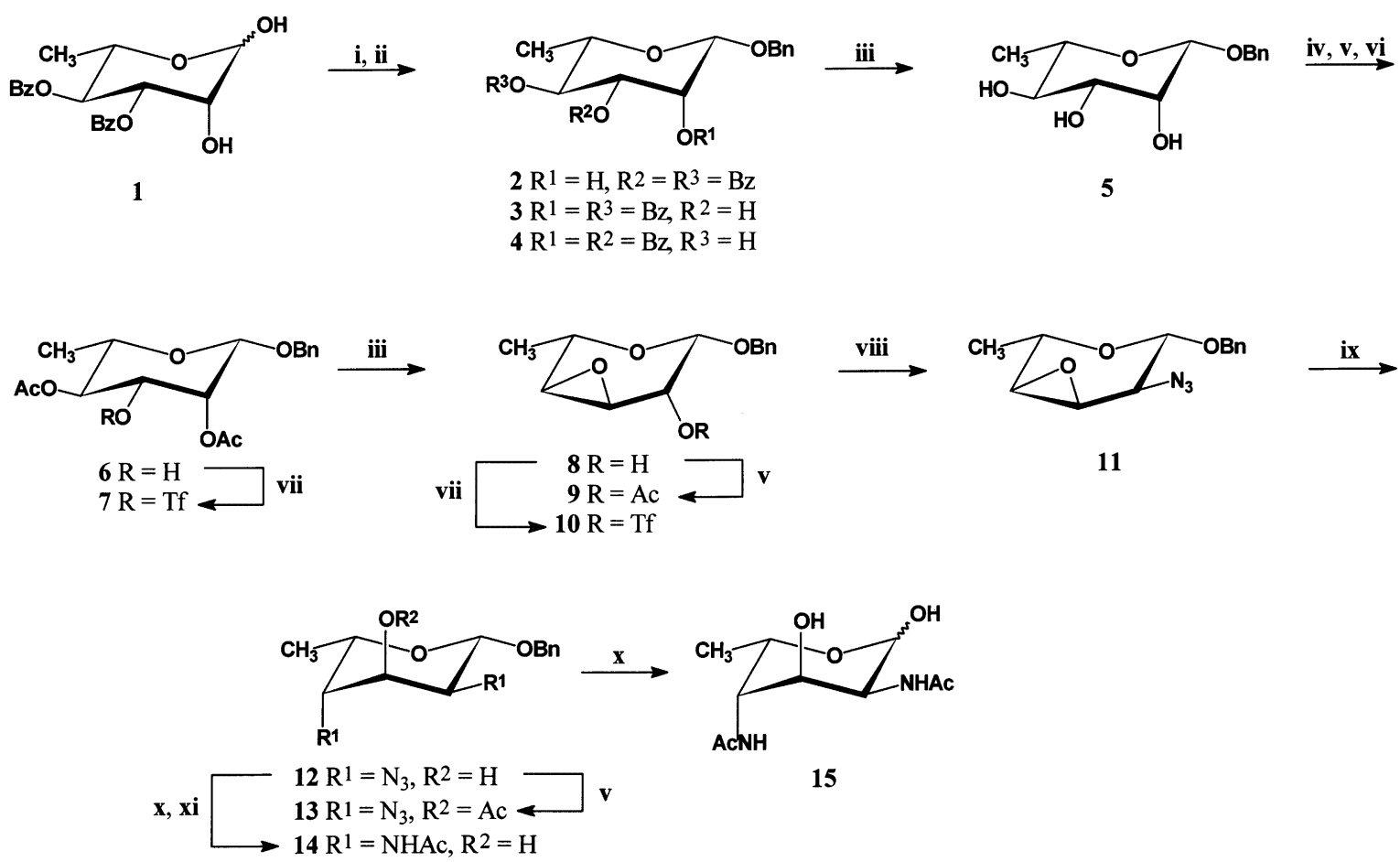

Scheme 1. Reagents and conditions: i, $\mathrm{Bu}_{2} \mathrm{SnO}$, benzene, reflux; ii, $\mathrm{BnBr}, \mathrm{Bu}_{4} \mathrm{NBr}$, benzene, reflux; iii, $\mathrm{MeONa}, \mathrm{MeOH}$; iv, trimethyl orthoacetate, PTSA, $\mathrm{MeCN}$, rt; v, $\mathrm{Ac}_{2} \mathrm{O}$, pyridine, rt; vi, $80 \%$ aq AcOH, rt; vii, $\mathrm{Tf}_{2} \mathrm{O}, \mathrm{pyridine} \mathrm{CH}_{2} \mathrm{Cl}_{2}, 0{ }^{\circ} \mathrm{C} ;$ viii, $\mathrm{NaN}_{3}$, $\mathrm{DMF}, \mathrm{rt}$; ix, $\mathrm{NaN}_{3}, \mathrm{NH}_{4} \mathrm{Cl}$, aq $\mathrm{EtOH}$, reflux; $\mathbf{x}, \mathrm{H}_{2}, \mathrm{Pd}(\mathrm{OH})_{2} / \mathrm{C}, \mathrm{MeOH}, 30^{\circ} \mathrm{C} ; \mathbf{x i}, \mathrm{Ac}_{2} \mathrm{O}, \mathrm{MeOH}, \mathrm{rt}$. 


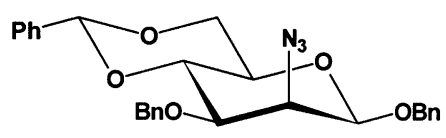

16

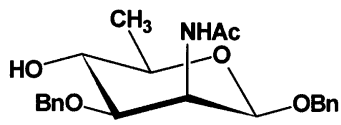

20

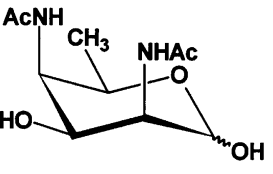

$25 p$
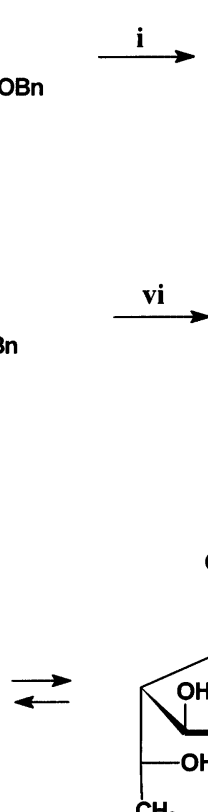

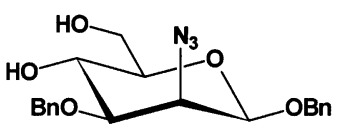

17
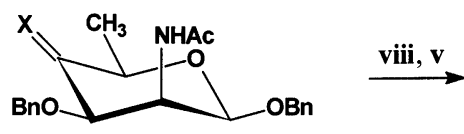

$21 \mathrm{X}=\mathrm{O}$

$22 \mathrm{X}=\mathrm{NOH}$
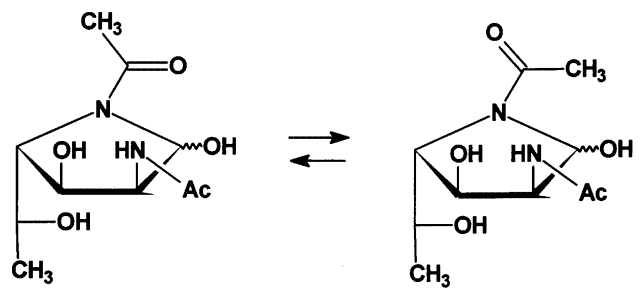

$25 f$

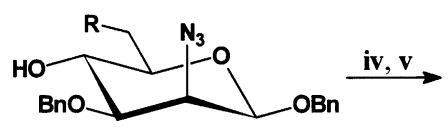

$18 \mathrm{R}=$ OTs
$19 \mathrm{R}=\mathrm{I}$

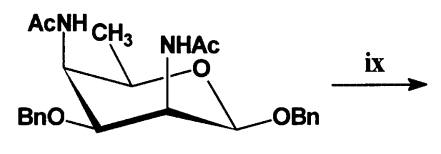

23

$+$

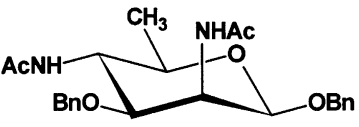

24

Scheme 2. Reagents and conditions: i, pyridinium perchlorate, aq $\mathrm{MeCN}, 80^{\circ} \mathrm{C}$; ii, $\mathrm{TsCl}$, pyridine, $0^{\circ} \mathrm{C} \rightarrow \mathrm{rt}$; iii, $\mathrm{NaI}, \mathrm{MeCN}$, $80{ }^{\circ} \mathrm{C}$; iv, $\mathrm{H}_{2}, \mathrm{Pd}(\mathrm{OH})_{2} / \mathrm{C}, i-\mathrm{Pr}_{2} \mathrm{NEt}, \mathrm{MeOH}, 30^{\circ} \mathrm{C}$; v, $\mathrm{Ac}_{2} \mathrm{O}, \mathrm{MeOH}, \mathrm{rt}$; vi, oxalyl chloride, $\mathrm{DMSO}, i-\mathrm{Pr}_{2} \mathrm{NEt}, \mathrm{CH}_{2} \mathrm{Cl}_{2},-60{ }^{\circ} \mathrm{C}$; vii, $\mathrm{NH}_{2} \mathrm{OH} \cdot \mathrm{HCl}$, pyridine, $\mathrm{CH}_{2} \mathrm{Cl}_{2}$, rt; viii, $\mathrm{NaBH}_{4}, \mathrm{NiCl}_{2} 6 \mathrm{H}_{2} \mathrm{O}, \mathrm{MeOH},-35^{\circ} \mathrm{C}$; ix, $\mathrm{H}_{2}, \mathrm{Pd}(\mathrm{OH})_{2} / \mathrm{C}, \mathrm{aq} \mathrm{MeOH}, \mathrm{rt}$.

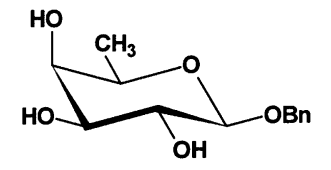

26

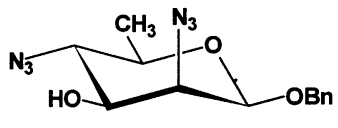

30
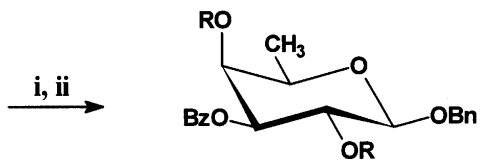

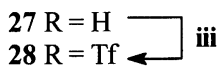
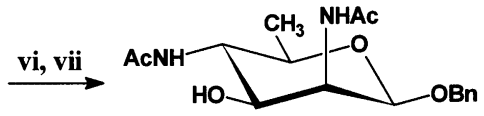

31
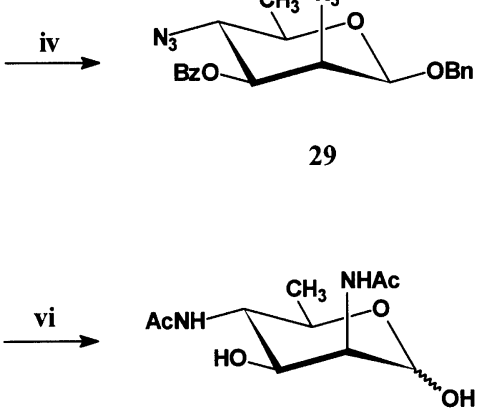

32

Scheme 3. Reagents and conditions: i, $\mathrm{Bu}_{2} \mathrm{SnO}$, benzene, reflux; ii, $\mathrm{BzCl}$, benzene, $0{ }^{\circ} \mathrm{C} \rightarrow \mathrm{rt}$; iii, $\mathrm{Tf}_{2} \mathrm{O}, \mathrm{pyridine} \mathrm{CH}_{2} \mathrm{Cl}_{2}, 0{ }^{\circ} \mathrm{C}$; iv, $\mathrm{Bu}_{4} \mathrm{NN}_{3}$, toluene, $60 \rightarrow 100^{\circ} \mathrm{C}$; v, $\mathrm{MeONa}, \mathrm{MeOH}$, rt; vi, $\mathrm{H}_{2}, \mathrm{Pd}(\mathrm{OH})_{2} / \mathrm{C}, \mathrm{MeOH}, 30^{\circ} \mathrm{C}$; vii, $\mathrm{Ac} \mathrm{C}_{2} \mathrm{O}, \mathrm{MeOH}, \mathrm{rt}$.

tion at $\delta 3.5-3.8$ of the signal for $\mathrm{H}-5$ (in $\alpha$-rhamnopyranosides $\mathrm{H}-5$ would resonate at $\delta$ $\left.4.1-4.3^{13}\right)$. The positions of the benzoyl groups in 2-4 were inferred from the low-field chemical shifts of the signals for $\mathrm{H}-3,4, \mathrm{H}-2,4$, and $\mathrm{H}-2,3$, respectively. Debenzoylation of the mixture of $\mathbf{2}-\mathbf{4}$ with sodium methoxide in methanol yielded $\mathbf{5}$.

Treatment of 5 with trimethyl orthoacetate in the presence of $\mathrm{TsOH}$, followed by acetylation of $\mathrm{OH}-4$ and hydrolytic opening of the orthoester ring in the 2,3-orthoester, yielded 2,4-diacetate 6. Low-field positions of the signals for $\mathrm{H}-2$ and $\mathrm{H}-4$ in the ${ }^{1} \mathrm{H}$ NMR spectrum proved the location of the acetyl groups in 6. Reaction of $\mathbf{6}$ with triflic anhydride in the presence of pyridine led to triflate 7, which readily gave the 3,4-anhydro-L-altroside 8 on treatment with sodium methoxide in methanol. The structure of $\mathbf{8}$, particularly the position of the epoxy group, was confirmed by NMR analysis of $\mathbf{8}$ and its acetate 9. The transformation of $\mathbf{8}$ into $\mathbf{9}$ resulted in a downfield shift of the signal for $\mathrm{H}-2(\delta 4.02 \rightarrow$ 


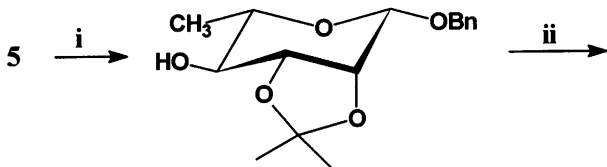

33

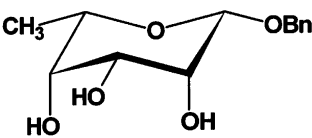

36
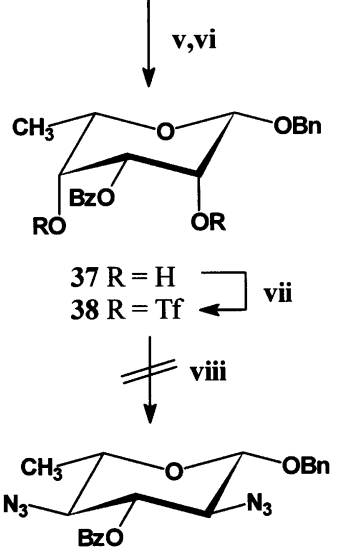

39

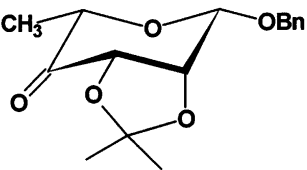

34
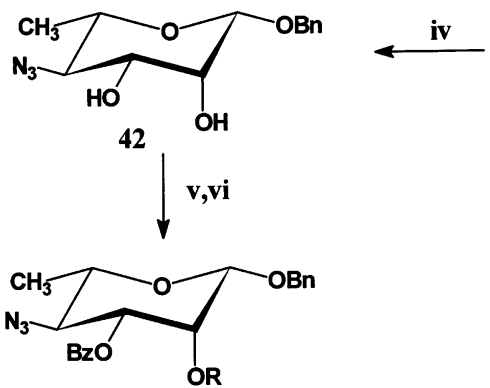

$43 \mathrm{R}=\mathrm{H}$
$44 \mathrm{R}=\mathrm{Tf}$

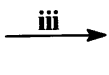

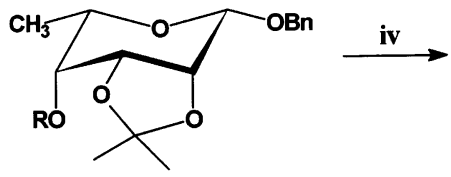

$$
\begin{aligned}
& 35 \mathrm{R}=\mathrm{H} \\
& 40 \mathrm{R}=\mathrm{Tf} \\
& \text { vii }
\end{aligned}
$$

$\downarrow \mathbf{i x}$
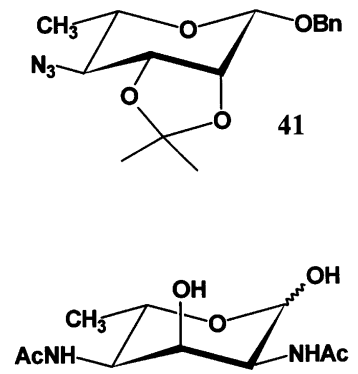

48
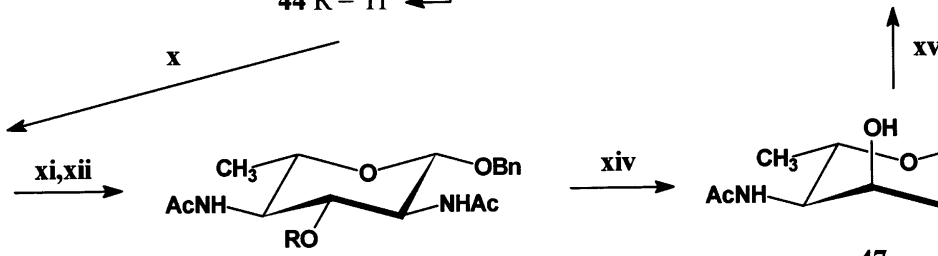

$45 \mathrm{R}=\mathrm{H}$
$46 \mathrm{R}=\mathrm{Ms} \rightleftarrows \mathrm{xiii}$

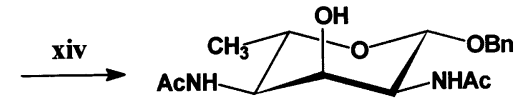

47

Scheme 4. Reagents and conditions: i, 2,2-dimethoxypropane, PTSA, acetone, rt; ii, oxalyl chloride, DMSO, $i$ - $\mathrm{Pr}_{2} \mathrm{NEt} \mathrm{CH}_{2} \mathrm{Cl}_{2}$, $-60{ }^{\circ} \mathrm{C}$; iii, $\mathrm{NaBH}_{4}$, aq EtOH, rt; iv, $80 \%$ aq AcOH, $40{ }^{\circ} \mathrm{C}$; $\mathbf{v}, \mathrm{Bu}_{2} \mathrm{SnO}$, benzene, reflux; vi, $\mathrm{BzCl}$, benzene, $0{ }^{\circ} \mathrm{C} \rightarrow \mathrm{rt}$; vii, $\mathrm{Tf}_{2} \mathrm{O}$, pyridine, $\mathrm{CH}_{2} \mathrm{Cl}_{2}, 0^{\circ} \mathrm{C}$; viii, $\mathrm{Bu}_{4} \mathrm{NN}_{3}$, toluene, $60^{\circ} \mathrm{C}$; ix, $\mathrm{NaN}_{3}, \mathrm{DMF}$, dibenzo-18-crown-6, rt; $\mathbf{x}, \mathrm{NaN}_{3}, \mathrm{DMF}$, rt; $\mathbf{x i}, \mathrm{LiAlH}_{4}$, THF, $0{ }^{\circ} \mathrm{C} \rightarrow \mathrm{rt}$; xii, $\mathrm{Ac}_{2} \mathrm{O}, \mathrm{MeOH}$, rt; xiii, $\mathrm{MsCl}$, pyridine, $\mathrm{CH}_{2} \mathrm{Cl}_{2}, 0{ }^{\circ} \mathrm{C} \rightarrow \mathrm{rt}$; xiv, AcONa, aq 2-methoxyethanol, reflux; xv, $\mathrm{H}_{2}$, $\mathrm{Pd}(\mathrm{OH})_{2} / \mathrm{C}$, aq $\mathrm{MeOH}, 35^{\circ} \mathrm{C}$.

5.25), thus indicating the position of the hydroxy group in $\mathbf{8}$. This finding excluded conversion of the 3,4-L-altro-epoxide into the 2,3-L-manno-isomer that might proceed under basic conditions. ${ }^{14}$ Compound $\mathbf{8}$ had the necessary configuration of $\mathrm{C}-3$, a free $\mathrm{OH}-2$ group required for subsequent introduction of an azido group, and a 3,4-epoxy function suitable for introduction of the second azido group at position 4 .

As anticipated, conversion of $\mathbf{8}$ into triflate $\mathbf{1 0}$ and subsequent reaction with sodium azide in DMF resulted in a high yield of azide 11. A large $J_{1,2}$ coupling constant value of $7.6 \mathrm{~Hz}$ in the ${ }^{1} \mathrm{H}$ NMR spectrum of $\mathbf{1 1}$ showed that the azido group was pseudo-equatorial. Opening of the epoxide ring in $\mathbf{1 1}$ by treatment with sodium azide in the presence of ammonium chloride in boiling aqueous ethanol ${ }^{15}$ furnished diazide 12. Large $J_{1,2}$ and small $J_{2,3}$,
$J_{3,4}$, and $J_{4,5}$ coupling constant values in the ${ }^{1} \mathrm{H}$ NMR spectra of $\mathbf{1 2}$ and the derived acetate 13 were in accordance with the $\beta$-L-gulo configuration. Chemical shifts for $\mathrm{H}-2(\delta$ $3.69), \mathrm{H}-3(\delta$ 5.33), and H-4 ( $\delta$ 3.48) in the spectrum of 13 demonstrated that the azido groups were at C-2 and C-4. Hydrogenolysis of 12 over $\mathrm{Pd}(\mathrm{OH})_{2} / \mathrm{C}$ reduced the azido groups, whereas the benzyl group remained intact (compare published data ${ }^{16}$ ). Following $\mathrm{N}$-acetylation, hydrogenolysis of the diacetamido derivative $\mathbf{1 4}$ proceeded smoothly providing the target sugar $\mathbf{1 5}$ in high yield. According to ${ }^{1} \mathrm{H}$ NMR data, 15 exists in aqueous solution in the pyranose form as a mixture of $\alpha$ - and $\beta$-anomers in a ratio of $\sim 1: 5$.

2-Azido-2-deoxy derivative $\mathbf{1 6}^{17}$ was used as a starting compound for preparation of 2,4-diacetamido-2,4,6-trideoxy-D-talose (25). De- 
Table 1

NMR data for 2,4-diacetamido-2,4,6-trideoxy-D-talose $25\left(\mathrm{D}_{2} \mathrm{O}, 30^{\circ} \mathrm{C}\right)$

Form

${ }^{1} \mathrm{H}$ NMR data (chemical shift, $\delta$; coupling constant, Hz) ${ }^{13} \mathrm{C}$ NMR data (chemical shifts, $\delta$ )

\begin{tabular}{lllllllllllll} 
(content, $\%)$ & $\mathrm{H}-1$ & $\mathrm{H}-2$ & $\mathrm{H}-3$ & $\mathrm{H}-4$ & $\mathrm{H}-5$ & $\mathrm{H}-6$ & $\mathrm{C}-1$ & $\mathrm{C}-2$ & $\mathrm{C}-3$ & $\mathrm{C}-4$ & $\mathrm{C}-5$ & $\mathrm{C}-6$ \\
& $\left(J_{1,2}\right)$ & $\left(J_{2,3}\right)$ & $\left(J_{3,4}\right)$ & $\left(J_{4,5}\right)$ & $\left(J_{5,6}\right)$ & & & & & & & \\
\hline$\alpha-25 p$ & 5.18 & 4.12 & 4.24 & 4.18 & 4.43 & 1.18 & 94.2 & 52.8 & 66.7 & 52.7 & 66.7 & 17.0 \\
$(18)$ & $(2.0)$ & $(4.6)$ & $(4.2)$ & $(2.8)$ & $(6.6)$ & & & & & & & \\
$\beta-25 p$ & 4.97 & 4.36 & 4.12 & 4.12 & 3.91 & 1.18 & 94.6 & 53.4 & 69.6 & 52.0 & 71.7 & 17.1 \\
$(32)$ & $(1.9)$ & $(4.2)$ & - & $(<1)$ & $(6.4)$ & & & & & & & \\
$\alpha-25 f$ major & 5.38 & 4.51 & 4.29 & 4.09 & 4.04 & 1.24 & 86.9 & 60.9 & 71.6 & 70.6 & 69.0 & 20.5 \\
$(20)$ & $(5.3)$ & $(5.0)$ & $(<1)$ & $(6.2)$ & $(6.3)$ & & & & & & & \\
$\alpha-25 f$ minor & 5.47 & 4.38 & 4.25 & 3.85 & 3.91 & 1.33 & 84.9 & 59.9 & 72.1 & 73.9 & 68.7 & 20.6 \\
$(14)$ & $(6.3)$ & $(4.8)$ & $(<1)$ & $(8.9)$ & $(6.2)$ & & & & & & & \\
$\beta-25 f$ major & 5.51 & 4.45 & 4.31 & 4.19 & 4.16 & 1.11 & 82.0 & 55.0 & 71.3 & 70.5 & 67.0 & 19.2 \\
$(13.5)$ & $(5.6)$ & $(4.9)$ & $(<1)$ & $(5.1)$ & $(6.5)$ & & & & & & & \\
$\beta-25 f$ minor & 5.58 & 4.38 & 4.25 & 3.98 & 3.77 & 1.25 & 80.0 & 53.4 & 72.8 & 71.9 & 67.9 & 20.0 \\
$(2.5)$ & $(6.2)$ & $(4.3)$ & $(<1)$ & $(7.9)$ & $(6.1)$ & & & & & & &
\end{tabular}

oxygenation at C-6 and introduction of an amino function with inversion of the configuration at $\mathrm{C}-4$ had to be carried out to obtain the desired structure. To this aim, the benzylidene group in $\mathbf{1 6}$ was removed by treatment with pyridinium perchlorate ${ }^{18}$ in aqueous acetonitrile (Scheme 2). Selective tosylation of the resulting diol 17, followed by substitution of the tosyloxy group in $\mathbf{1 8}$ with iodide, afforded the 6-iodo derivative, 19. Simultaneous reduction of the azido group and deiodination without affecting the benzyl protective groups occurred on hydrogenation over $\mathrm{Pd}(\mathrm{OH})_{2} / \mathrm{C}$ in the presence of $N, N$-diisopropylethylamine. Following N-acetylation, the 2-acetamido-2,6dideoxy derivative 20 was obtained in $84 \%$ yield. The use of $\mathrm{LiAlH}_{4}$ in THF for reduction of $\mathbf{1 9}$ was less effective giving only $49 \%$ of $\mathbf{2 0}$. A direct $\mathrm{S}_{\mathrm{N}} 2$ substitution at C-4 in the manno series is known to be complicated; ${ }^{19}$ therefore, the reaction sequence oxidation-oximation-reduction was applied to introduce the second amino group into 20. Swern oxidation of $\mathbf{2 0}$ gave the ketone 21, which was converted, without isolation, into the oxime 22. Reduction of the latter with $\mathrm{NaBH}_{4}-\mathrm{NiCl}_{2}$ in methanol at $-35^{\circ} \mathrm{C}^{20}$ and subsequent $\mathrm{N}$ acetylation gave a mixture of talo and manno isomers $\mathbf{2 3}$ and $\mathbf{2 4}$ in a ratio of $8: 1$. The structures of $\mathbf{2 3}$ and 24 were proved by ${ }^{1} \mathrm{H}$ NMR spectroscopy. Large $J_{3,4}$ and $J_{4,5}$ coupling constant values (each of $\sim 10 \mathrm{~Hz}$ ) and a small $J_{2,3}$ value $(4.2 \mathrm{~Hz})$ showed 24 to have the manno configuration. No well-resolved spectrum could be obtained for $\mathbf{2 3}$ even at elevated temperatures that could be accounted for by a restricted internal rotation of spatially close axial acetamido groups at $\mathrm{C}-2$ and $\mathrm{C}-4$ and the 3-O-benzyl group. Nevertheless, based on the line width for H-3 and H-5, it was concluded that $J_{2,3}$ and $J_{3,4}$ coupling constant values did not exceed $4 \mathrm{~Hz}$ and $J_{4,5}$ was less than $2 \mathrm{~Hz}$. These data were in good agreement with the expected talo configuration of $\mathbf{2 3}{ }^{21}$ Hydrogenolysis of $\mathbf{2 3}$ over $\mathrm{Pd}(\mathrm{OH})_{2} / \mathrm{C}$ afforded the target hexose $\mathbf{2 5}$.

The behaviour of $\mathbf{2 5}$ in aqueous solution is noteworthy. The ${ }^{1} \mathrm{H}$ and ${ }^{13} \mathrm{C}$ NMR spectra of 25, which were assigned using 2D COSY, TOCSY, and HSQC techniques (Table 1), contained six anomeric signals. Comparison with published data for talopyranose and its derivatives, including ${ }^{13} \mathrm{C}$ NMR chemical shifts and coupling constant values, ${ }^{21,22}$ enabled identification of $\alpha$ - and $\beta$-pyranoses $\alpha$ $25 \boldsymbol{p}$ and $\boldsymbol{\beta}-25 \boldsymbol{p}$. The four other signals belonged to $\alpha$ - and $\beta$-furanoses $\alpha-25 f$ and $\boldsymbol{\beta}-25 f$, as followed from the coupling constant values (compare published data ${ }^{23}$ ) and characteristic changes in the ${ }^{13} \mathrm{C}$ NMR chemical shifts, especially those for C-1 and C-4, compared to the data of talofuranose $\mathrm{e}^{22}$ and $\mathbf{2 5 p}$ (Table 1). Each of $\boldsymbol{\alpha - 2 5} \boldsymbol{f}$ and $\boldsymbol{\beta}-\mathbf{2 5} \boldsymbol{f}$ existed as two stereoisomers $(E$ and $Z)$ at the 4-acetamido group, ${ }^{24}$ which were not assigned, and designated as major and minor (Table 1). The 
${ }^{1} \mathrm{H}$ NMR signals for the stereoisomers within each anomeric pair coalesced when the spectrum was run at $90^{\circ} \mathrm{C}$. Therefore, 2,4-diacetamido-2,4,6-trideoxy-D-talose represents a rare example of a 4-acylamino-4deoxyhexose that exists in aqueous solution to a significant extent in the furanose form. Most likely, the reason for this unusual behavior is destabilization of the pyranose form by unfavourable 1,3-diaxial interaction of the acetamido groups.

2,4-Diacetamido-2,4,6-trideoxy-D-mannose (32) was prepared from benzyl $\beta$-D-fucopyranoside (26) ${ }^{25}$ using at the key step the known approach to $\beta$-mannosides based on simultaneous substitution with inversion at positions 2 and 4 in $\beta$-galactosides ${ }^{26}$ (Scheme 3). $\mathrm{Bu}_{2} \mathrm{SnO}$-mediated selective benzoylation of $\mathbf{2 6}$ gave 3-benzoate $\mathbf{2 7}$, as followed from a lowfield position of the signal for $\mathrm{H}-3$ in the ${ }^{1} \mathrm{H}$ NMR spectrum. Conversion of 27 into ditriflate $\mathbf{2 8}$ and its subsequent reaction with tetrabutylammonium azide in toluene resulted in diazide 29 in high yield. Large $J_{3,4}$ and $J_{4,5}$ coupling constant values (each of $\sim 10 \mathrm{~Hz}$ ) and small $J_{1,2}$ and $J_{2,3}$ values ( $<1$ and $2.5 \mathrm{~Hz}$, respectively) in the ${ }^{1} \mathrm{H}$ NMR spectrum confirmed the manno configuration of 29 . Conventional debenzoylation of 29 afforded $\mathbf{3 0}$. Further transformations of $\mathbf{3 0}$ were similar to those described above in synthesis of $\mathbf{1 5}$ and included reduction of the azido groups by hydrogenation, N-acetylation $(\mathbf{3 0} \rightarrow \mathbf{3 1})$, and removal of the benzyl protecting group $(31 \rightarrow$ 32). According to NMR data, the hexose 32 exists in aqueous solution exclusively in the pyranose form $(\alpha, \beta$ ratio $\sim 1: 1)$.

Benzyl $\beta$-L-rhamnopyranoside 5 was chosen as the starting compound for preparation of 2,4-diacetamido-2,4,6-trideoxy-L-allose (48). To provide the proper D configuration at C-4, which would lead to the necessary L configuration on azidation, the L-rhamnoside $\mathbf{5}$ was converted into L-taloside 35 (Scheme 4). Conventional isopropylidenation of $\mathbf{5}$ gave $\mathbf{3 3}$, which was subjected to the known ${ }^{27}$ oxidation-reduction procedure to afford, via ketone 34, L-taloside 35 in nearly quantitative yield. In an attempt to apply the same approach that was successively used for the synthesis of the manno isomer 32, the isopropylidene group was removed and the resulting triol $\mathbf{3 6}$ was selectively benzoylated via dibutylstannylene derivative to yield monobenzoate 37. However, instead of the expected diazide 39, reaction of 2,4-ditriflate 38 obtained from 37 with tetrabutylammonium azide gave a complex mixture of products that was not further investigated. Therefore, another approach based on a consecutive introduction of azido groups to positions 4 and 2 was exploited. Azidation of 4-triflate $\mathbf{4 0}$ with sodium azide in $\mathrm{DMF}$ in the presence of a crown ether ${ }^{28}$ furnished azide 41 with the necessary configuration of C-4. To liberate HO-2 for introduction of the second azido group, $\mathbf{4 1}$ was subjected to deacetalation followed by $\mathrm{Bu}_{2} \mathrm{SnO}$-mediated selective 3-O-benzoylation of diol $\mathbf{4 2}$. Monobenzoate 43 thus obtained was converted into triflate $\mathbf{4 4}$, which was then converted to the target diazide $\mathbf{3 9}$ by reaction with sodium azide in DMF. Large values of all coupling constants in the ${ }^{1} \mathrm{H}$ NMR spectrum proved unambiguously the L-gluco configuration of 39. $\mathrm{LiAlH}_{4}$ reduction of azido groups in $\mathbf{3 9}$ with concomitant removal of the benzoyl group and subsequent $\mathrm{N}$-acetylation resulted in the diacetamido derivative $\mathbf{4 5}$. $\mathrm{Me}$ sylation of $\mathbf{4 5}$ afforded mesylate $\mathbf{4 6}$. Inversion of the configuration at C-3 mediated by participation of a neighbouring acetamido group(s) was achieved by heating of $\mathbf{4 6}$ in aqueous 2-methoxyethanol in the presence of sodium acetate ${ }^{16}$ to give the L-allo derivative 47 in high yield. The configuration of $\mathbf{4 7}$ was confirmed by large $J_{1,2}$ and $J_{4,5}$ coupling constant values $\left(8.6\right.$ and $10.2 \mathrm{~Hz}$ ) and small $J_{2,3}$ and $J_{3,4}$ values (2.8 and $2.3 \mathrm{~Hz}$, respectively). Conventional removal of the anomeric benzyl group afforded hexose 48, which occurred in the pyranose form $(\alpha, \beta$ ratio of 1:3.3, NMR data).

Condensation of compounds $15,25,32$, and 48 with oxalacetic acid was performed in the presence of sodium tetraborate at $\mathrm{pH} 10.5^{9}$ (Scheme 5). Acidic reaction products were isolated by anion exchange chromatography, and then the individual isomers of 5,7diacetamido-3,5,7,9-tetradeoxynon-2-ulosonic acids were separated by reversed-phase $\mathrm{C}_{18}$ HPLC. 


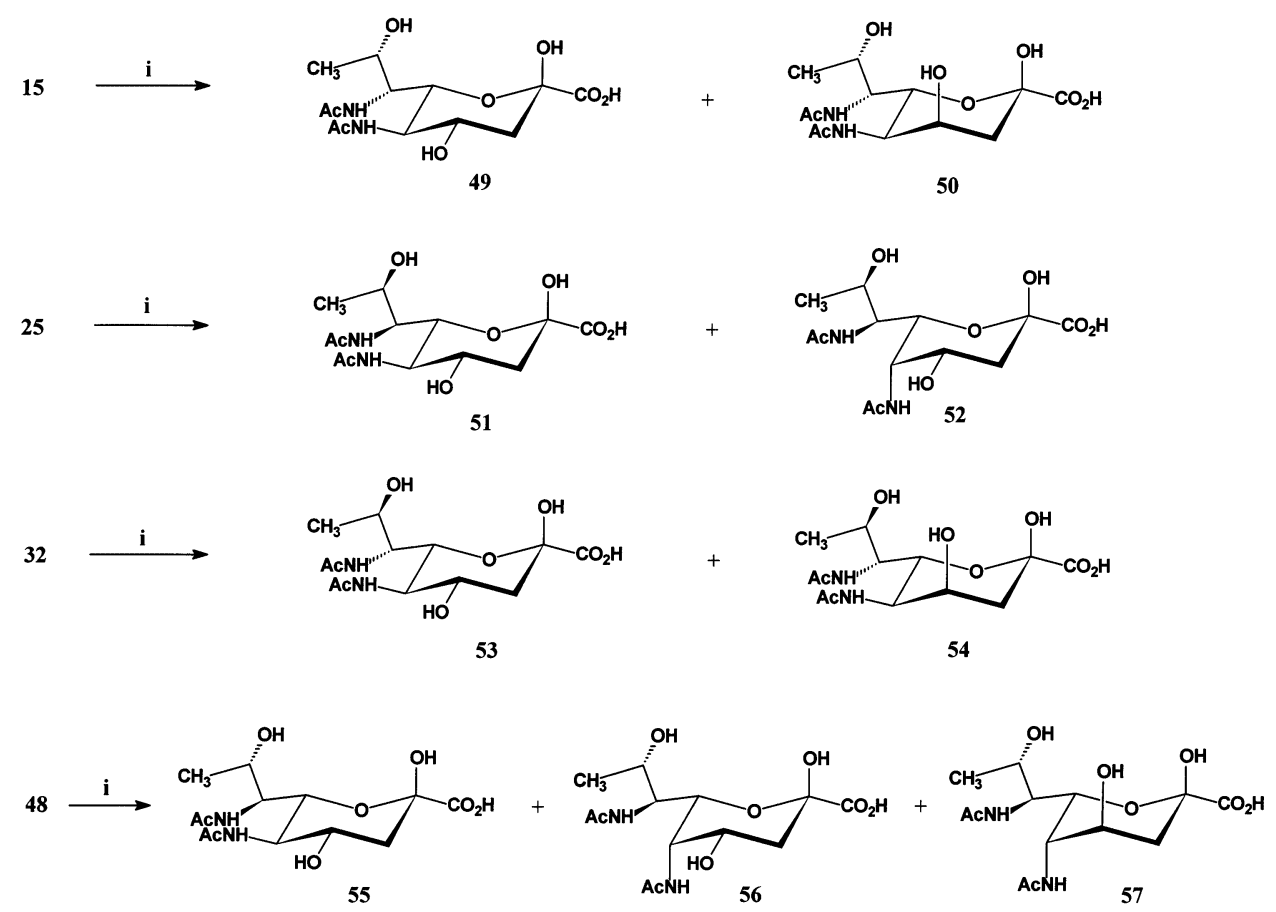

Scheme 5. Reagents and conditions: $\mathbf{i}$, oxalacetic acid, $\mathrm{Na}_{2} \mathrm{~B}_{4} \mathrm{O}_{7}, \mathrm{pH} 10.5$, rt Only main isomers of acids $\mathbf{4 9}-\mathbf{5 7}$ with an equatorial carboxyl group are shown.

Compounds 15 and 32 with the threo configuration of the fragment C-3-C-4 afforded pairs of epimers at C-4 having the L-glycero-D-galacto/D-talo (49/50) and D-glycero-D-galacto/D-talo (53/54) configurations, respectively, in a nearly 1:1 ratio. Compounds $\mathbf{2 5}$ and $\mathbf{4 8}$ with the erythro configuration of the fragment $\mathrm{C}-3-\mathrm{C}-4$ gave the equatorial HO-4 epimers having the D-glycero-L-altro (51) and L-glycero-L-altro (55) configuration, respectively, with no axial HO-4 epimers. The reason for this unexpected stereoselectivity is not clear. In addition to $\mathbf{5 1}$ and $\mathbf{5 5}$, compounds 25 and 48 afforded, as minor products, isomeric nonulosonic acids with an axial AcNH-5 group having the D-glycero-L-manno (52), L-glycero-L-manno( 56), and L-glyceroL-gluco (57) configuration. They evidently resulted from epimerisation at C-2 in the starting monosaccharides prior to condensation.

The structures of the synthesised acids were proved by ESIMS and NMR spectral data. Major peaks corresponding to either $[\mathrm{M}+$ $\mathrm{Na}]^{+}$(positive mode) or $[\mathrm{M}-\mathrm{H}]^{-}$(negative mode) pseudomolecular ions were observed in the ESIMS spectra of 49-57. The data of the ${ }^{1} \mathrm{H}$ and ${ }^{13} \mathrm{C}$ NMR spectra of both free acids and sodium salts are given in Tables 2 and 3 .
They demonstrated the pyranose form of all sugars, which existed in aqueous solution as mixtures of anomers with a high predominance of the anomer having an equatorial carboxyl group ( $\beta$ for $49,50,53$, and 54 , and $\alpha$ for 51, 52, 55-57). The ratios of the free acids anomers are given in Table 2. The configuration within the pyranose ring followed from the ${ }^{3} J_{\mathrm{H}, \mathrm{H}}$ coupling constant values determined from the ${ }^{1} \mathrm{H}$ NMR spectra. Large $J_{3 \mathrm{a}, 4}, J_{4,5}$, and $J_{5,6}$ values for $\mathbf{4 9}, \mathbf{5 1}, \mathbf{5 3}$, and $\mathbf{5 5}$ indicated equatorial substituents at C-4, C-5, and C-6. Large $J_{5,6}$ and small $J_{3 \mathrm{a}, 4}$ and $J_{4,5}$ values for $\mathbf{5 0}$ and $\mathbf{5 4}$ showed that the $\mathrm{OH}-4$ group is axial. In contrast, large $J_{3 \mathrm{a}, 4}$ and small $J_{4,5}$ and $J_{5,6}$ values for $\mathbf{5 2}$ and $\mathbf{5 6}$ confirmed the axial orientation of the AcNH-5 group. Finally, small $J_{3 \mathrm{a}, 4}, J_{4,5}$, and $J_{5,6}$ values for 57 demonstrated that both OH-4 and AcNH-5 are axial.

Four of the synthesised isomers occur in nature. These are the D-glycero-D-galacto and L-glycero-L-manno isomers called legionaminic ${ }^{3,8}$ and pseudaminic ${ }^{1}$ acid, respectively, as well as C-4 and C-8 epimers of legionaminic acid having the D-glycero-D-talo and L-glycero-D-galacto configuration (4- and 
Table 2

${ }^{1} \mathrm{H}$ NMR data for 5,7-diacetamido-3,5,7,9-tetradeoxynon-2-ulosonic acids $\left(\delta_{\mathrm{H}} ; J_{\mathrm{H}, \mathrm{H}}, \mathrm{Hz} ; \mathrm{D}_{2} \mathrm{O}, 30{ }^{\circ} \mathrm{C}\right)$

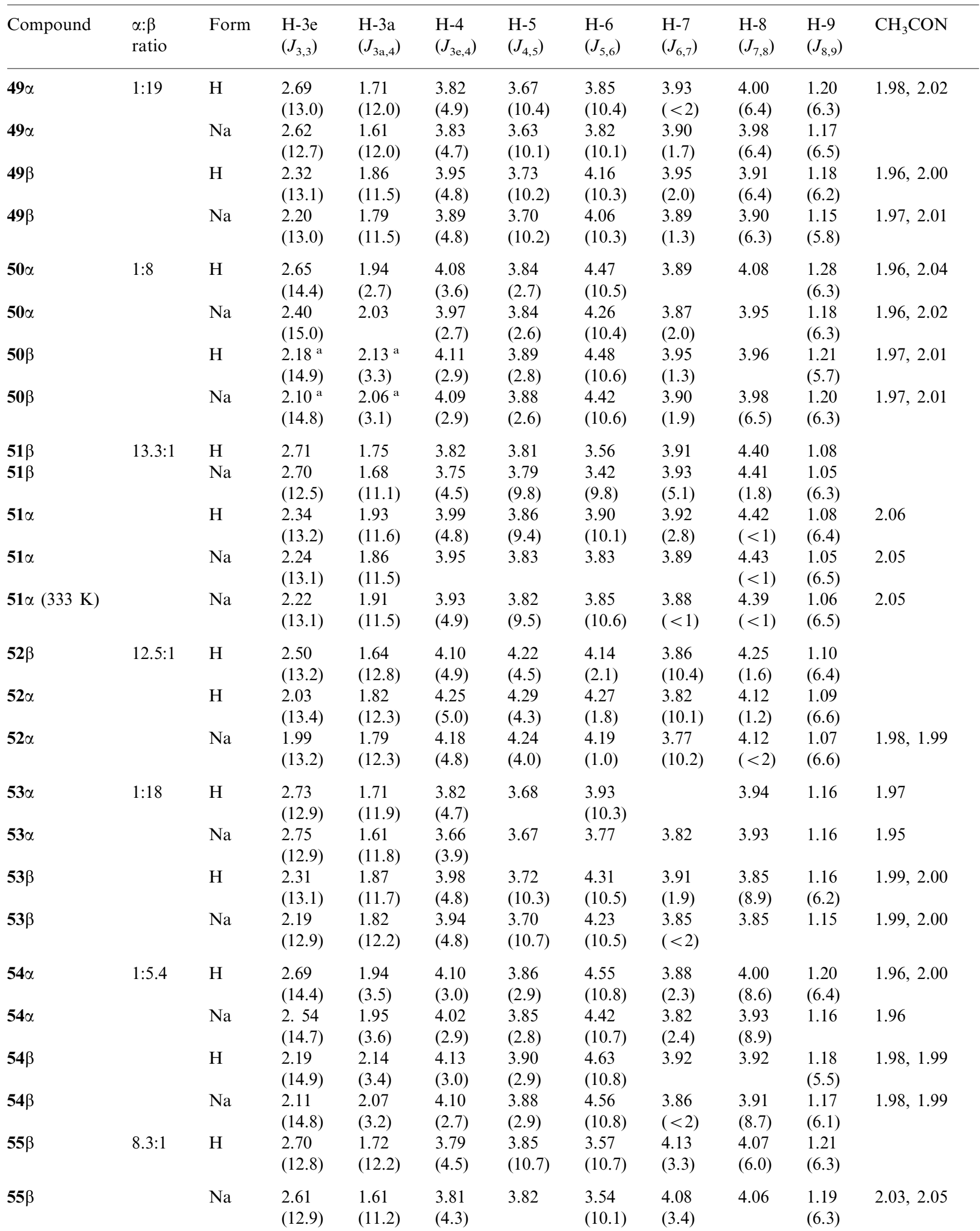


Table 2 (Continued)

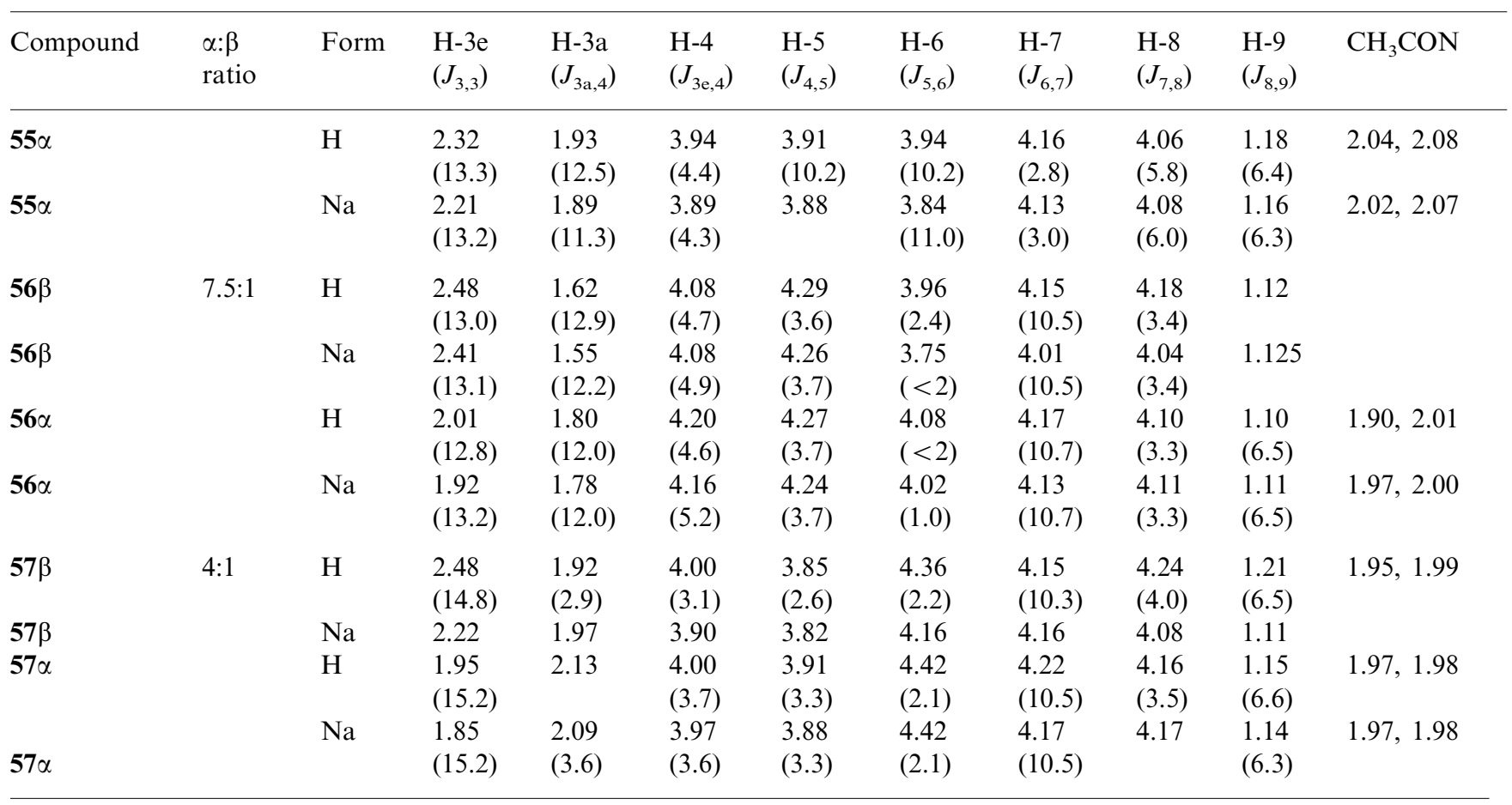

a Assignment could be interchanged.

8-epilegionaminic acid, respectively). Using the synthetic models 53, 54, and 49, the configurations of legionaminic, 4- and 8-epilegionaminic acids were confirmed in some bacterial polysaccharides and revised in others. ${ }^{8}$ The ${ }^{1} \mathrm{H}$ and ${ }^{13} \mathrm{C}$ NMR spectroscopy and specific optical rotation data of the compound $\mathbf{5 6}$ fitted reasonably well those of pseudaminic acid derivatives isolated from bacterial polysaccharides ${ }^{4,29}$, thus confirming the L-glycero-L-manno configuration of the natural monosaccharide.

Comparison of the NMR data of various isomers (Tables 2 and 3, free acids) revealed several regularities, which can be useful for determination of the configuration of naturally occurring compounds of this class. Thus, the $J_{6,7}$ coupling constant is dependent on the configuration at C-5: it is small $(1.3-3.3 \mathrm{~Hz})$ when AcNH-5 is equatorial (49-51, 53-55) and large $(10.1-10.7 \mathrm{~Hz})$ when it is axial $(\mathbf{5 2}$, $\mathbf{5 6}, 57$ ), indicating the syn (gauche)- and translike relationship for $\mathrm{H}-6$ and $\mathrm{H}-7$, respectively. In the D-galacto and D-talo isomers, when $\mathrm{C}-8$ had the D configuration $(\mathbf{5 3}, \mathbf{5 4})$, the $\mathrm{C}-6$ and C-8 signals appeared upfield by $2.0-2.3$ and 1.4-2.0 ppm, respectively, compared to the corresponding $\mathrm{L}$ epimers $(49,50)$. In the $\mathrm{L}-$ manno isomers, a significant difference was observed for the C-9 signal, which appeared at $20.0 \mathrm{ppm}$ in the D epimer (52) at C-8 but at $16.7 \mathrm{ppm}$ in the L epimer (56).

The chemical shifts are influenced also by the anomeric configuration. In the sugars with an equatorial $\mathrm{OH}-4(\mathbf{4 9}, \mathbf{5 1}-\mathbf{5 3}, \mathbf{5 5}, \mathbf{5 6})$, the difference between the ${ }^{1} \mathrm{H}$ NMR resonances for $\mathrm{H}-3_{\mathrm{ax}}$ and $\mathrm{H}-3_{\text {eq }}$ was $0.86-1.02 \mathrm{ppm}$ for the anomer with an axial carboxyl group but only $0.21-0.46 \mathrm{ppm}$ for the other anomer, independently of whether AcNH-5 is axial or equatorial. When $\mathrm{OH}-4$ was axial and $\mathrm{AcNH}-$ 5 equatorial $(\mathbf{5 0}, \mathbf{5 4})$, a typical difference of $0.71-0.75$ or $0.05 \mathrm{ppm}$ was observed for the anomers with an axial or an equatorial carboxyl group, respectively. In the ${ }^{13} \mathrm{C}$ NMR spectra, the clearest dependence was shown by the $\mathrm{C}-3$ and $\mathrm{C}-6$ resonances. Compared to the other anomer, in the anomer with an axial carboxyl group they both appeared upfield by $0.8-1.3$ and $1.6-2.9 \mathrm{ppm}$ when $\mathrm{OH}-4$ was equatorial $(\mathbf{4 9}, \mathbf{5 1}-\mathbf{5 3}, \mathbf{5 5}, \mathbf{5 6})$ or by $2.3-2.6$ and $3.8-4.7 \mathrm{ppm}$, respectively, when $\mathrm{OH}-4$ was axial $(\mathbf{5 0}, \mathbf{5 4}, \mathbf{5 7})$.

For conformational studies by NMR spectroscopy, the L-glycero-D-galacto (49), D-glycero-L-altro (51), D-glycero-D-galacto (53), and 
Table 3

${ }^{13} \mathrm{C}$ NMR data of 5,7-diacetamido-3,5,7,9-tetradeoxynon-2-ulosonic acids $\left(\delta_{\mathrm{C}} ; \mathrm{D}_{2} \mathrm{O}, 30{ }^{\circ} \mathrm{C}\right)$

\begin{tabular}{|c|c|c|c|c|c|c|c|c|c|c|c|c|}
\hline & Form & $\mathrm{C}-1$ & $\mathrm{C}-2$ & $\mathrm{C}-3$ & $\mathrm{C}-4$ & C-5 & C-6 & $\mathrm{C}-7$ & C-8 & C-9 & $\mathrm{CH}_{3} \mathrm{CON}$ & $\mathrm{CH}_{3} \mathrm{CON}$ \\
\hline $49 \alpha$ & $\mathrm{H}$ & 173.1 & 97.3 & 41.2 & 68.9 & 53.7 & 75.2 & 54.4 & 69.4 & 19.8 & & \\
\hline $49 \alpha$ & $\mathrm{Na}$ & 176.7 & 98.2 & 41.7 & 69.7 & 54.2 & 75.2 & 54.4 & 70.1 & 19.8 & & \\
\hline $49 \beta$ & $\mathrm{H}$ & 174.3 & 96.5 & 40.4 & 68.3 & 54.1 & 72.9 & 54.4 & 69.3 & 19.8 & $23.1,23.4$ & $175.1,175.2$ \\
\hline $49 \beta$ & $\mathrm{Na}$ & 177.3 & 97.5 & 40.8 & 68.6 & 54.2 & 72.9 & 54.4 & 69.7 & 19.8 & $23.1,23.4$ & $175.1,175.3$ \\
\hline $\mathbf{5 0} \alpha$ & $\mathrm{H}$ & & & 40.0 & 66.6 & 50.1 & 72.6 & 54.9 & 69.7 & 19.9 & & \\
\hline $50 \alpha$ & $\mathrm{Na}$ & 176.1 & 96.5 & 38.9 & 66.7 & 50.4 & 72.2 & 54.9 & & 19.9 & & \\
\hline $50 \beta$ & $\mathrm{H}$ & $174.5^{\mathrm{a}}$ & 96.1 & 37.7 & 66.9 & 50.0 & 68.5 & 54.9 & 69.2 & 19.9 & $23.0,23.1$ & $174.6^{\mathrm{a}}, 175.2$ \\
\hline $50 \beta$ & $\mathrm{Na}$ & 177.3 & 97.1 & 37.8 & 67.4 & 50.1 & 68.7 & 54.7 & 69.7 & 19.9 & $23.0,23.1$ & $174.5,175.2$ \\
\hline $51 \beta$ & $\mathrm{H}$ & 172.9 & 97.2 & 41.1 & 68.7 & 54.7 & 77.3 & 54.3 & 66.5 & 20.0 & & \\
\hline $51 \beta$ & $\mathrm{Na}$ & 175.6 & 97.4 & 41.7 & 69.5 & 55.4 & 76.0 & 54.9 & 66.5 & 20.2 & & \\
\hline $51 \alpha$ & $\mathrm{H}$ & 173.7 & 96.1 & 39.9 & 67.6 & 54.7 & 75.7 & 53.9 & 66.6 & 20.2 & $23.1,23.3$ & $175.2,175.8$ \\
\hline $51 \alpha$ & $\mathrm{Na}$ & 177.1 & 97.2 & 40.4 & 68.1 & 54.9 & 75.9 & 53.5 & 66.5 & 20.3 & $23.1,23.3$ & $175.2,175.8$ \\
\hline $52 \beta$ & $\mathrm{H}$ & 173.9 & 96.0 & 36.8 & 68.0 & 49.1 & 73.0 & 54.4 & 67.4 & 20.0 & & \\
\hline $52 \alpha$ & $\mathrm{H}$ & 174.7 & 96.8 & 35.5 & 66.1 & 49.9 & 70.3 & 54.4 & 66.0 & 20.0 & $23.1,23.2$ & $175.0,175$ \\
\hline $52 \alpha$ & $\mathrm{Na}$ & 177.6 & 97.8 & 36.0 & 66.7 & 50.1 & 70.2 & 54.6 & 66.0 & 20.0 & $22.3,22.3$ & $174.2,175.0$ \\
\hline $53 \alpha$ & $\mathrm{H}$ & & 97.2 & 41.4 & 69.2 & 53.4 & 73.2 & 54.4 & 68.0 & 20.4 & & \\
\hline $53 \alpha$ & $\mathrm{Na}$ & 176.6 & 98.6 & 41.9 & 70.1 & 53.4 & 72.8 & 54.8 & 68.2 & 20.4 & & \\
\hline $53 \beta$ & $\mathrm{H}$ & $174.4^{\mathrm{a}}$ & 96.6 & 40.3 & 68.4 & 53.9 & 70.9 & 54.4 & 67.5 & 20.4 & $23.0,23.4$ & $175.0^{\mathrm{a}}, 175.2$ \\
\hline $53 \beta$ & $\mathrm{Na}$ & 177.6 & 97.6 & 40.8 & 68.8 & 54.0 & 70.7 & 54.5 & 67.7 & 20.4 & $23.0,23.4$ & $175.0,175.1$ \\
\hline $54 \alpha$ & $\mathrm{H}$ & & & 40.2 & 66.9 & 49.7 & 70.3 & 55.0 & 68.2 & 19.8 & & \\
\hline $54 \alpha$ & $\mathrm{Na}$ & 177.0 & 96.7 & 39.5 & 67.1 & 50.1 & 69.9 & 55.0 & 67.8 & 19.8 & & \\
\hline $54 \beta$ & $\mathrm{H}$ & $174.7^{\mathrm{a}}$ & 96.3 & 37.6 & 67.1 & 49.7 & 66.5 & 54.7 & 67.2 & 20.4 & $23.0,23.1$ & $174.7^{\mathrm{a}}, 175.0$ \\
\hline $54 \beta$ & $\mathrm{Na}$ & 177.6 & 97.3 & 37.8 & 67.6 & 49.9 & 66.2 & 54.8 & 67.4 & 20.4 & $22.9,23.1$ & $174.5,174.9$ \\
\hline $55 \beta$ & $\mathrm{H}$ & 173.0 & 97.0 & 41.2 & 69.1 & 54.9 & 76.0 & 55.8 & 67.8 & 19.7 & & \\
\hline $55 \beta$ & $\mathrm{Na}$ & 175.4 & 98.0 & 41.7 & 69.8 & 55.2 & 75.8 & 55.9 & 67.8 & 19.8 & & \\
\hline $55 \alpha$ & $\mathrm{H}$ & 173.7 & 96.1 & 39.9 & 68.2 & 55.3 & 73.7 & 55.5 & 67.6 & 19.7 & $23.3,23.4$ & $175.0,175.9$ \\
\hline $55 \alpha$ & $\mathrm{Na}$ & 177.1 & 97.1 & 40.4 & 68.9 & 55.7 & 73.8 & 55.2 & 67.6 & 19.8 & $23.2,23.5$ & $174.9,175.8$ \\
\hline $56 \beta$ & $\mathrm{H}$ & & & 35.0 & 67.3 & 49.9 & 72.1 & 53.8 & 68.2 & 16.7 & & \\
\hline $56 \beta$ & $\mathrm{Na}$ & & & 35.9 & 67.0 & 50.1 & 72.2 & 54.2 & 68.3 & 16.6 & & \\
\hline $56 \alpha$ & $\mathrm{H}$ & 174.9 & 97.0 & 35.6 & 66.1 & 49.9 & 71.4 & 54.0 & 68.1 & 16.7 & $23.2,23.3$ & $175.0,175.9$ \\
\hline $56 \alpha$ & $\mathrm{Na}$ & 177.4 & 97.7 & 36.0 & 66.5 & 50.1 & 71.4 & 54.2 & 68.1 & 16.6 & $23.1,23.3$ & $175.0,175.9$ \\
\hline $57 \beta$ & $\mathrm{H}$ & & 93.5 & 35.7 & 67.4 & 48.5 & 71.8 & 54.4 & 68.6 & 17.0 & & \\
\hline $57 \beta$ & $\mathrm{Na}$ & & & 34.8 & 67.6 & 49.5 & 71.5 & 53.8 & 68.6 & 17.0 & & \\
\hline $57 \alpha$ & $\mathrm{H}$ & 174.6 & 96.4 & 33.3 & 67.1 & 48.9 & 67.1 & 53.8 & 67.9 & 16.7 & $23.0,23.2$ & 175.1 \\
\hline $57 \alpha$ & $\mathrm{Na}$ & 174.9 & 97.3 & 33.5 & 67.6 & 49.0 & 67.0 & 54.1 & 68.1 & 16.7 & $23.0,23.2$ & 175.1 \\
\hline
\end{tabular}

a Assignment could be interchanged.

L-glycero-L-altro (55) isomers were converted to methyl esters 58-61 and then acetylated to 2,4,8-tri- $O$-acetyl derivatives $\mathbf{6 2}-\mathbf{6 5}$, respectively. These compounds were more convenient to analyze than the free acids because of a wider range of ${ }^{1} \mathrm{H}$ NMR chemical shifts and easier observation of signals for $\mathrm{NH}$ protons.

The L- and D-glycero-D-galacto esters 58 and 60 afforded mixtures of $\alpha$ - and $\beta$-acetates, 62 and 64 , in a 1:1 ratio. The D-and L-glycero-Laltro esters 59 and 61, which differed from 58 and 60 in the configuration of C-7, gave predominantly $\alpha$-acetates $(\alpha: \beta$ ratios were $13: 1$ and 6:1 for 63 and 65, respectively). The anomeric configurations in 62-65 were assigned based on the ${ }^{1} \mathrm{H}$ and ${ }^{13} \mathrm{C}$ NMR data (Table 4) by analogy with anomers of methyl $N$-acetylneuraminate pentaacetate. ${ }^{30,31}$ The ${ }^{3} J_{\mathrm{H}, \mathrm{H}}$ coupling constant values in the acetates $62-65$ and the parent free acids were essentially the same, and, hence, O-acetylation did not significantly change the conformation of the molecules. 
Table 4

${ }^{1} \mathrm{H}$ and ${ }^{13} \mathrm{C}$ NMR data of methyl (5,7-diacetamido-2,4,8-tri- $O$-acetyl-3,5,7,9-tetradeoxynon-2-ulopyranos)onates $\left(\delta_{\mathrm{H}} ; \delta_{\mathrm{C}} ; J_{\mathrm{H}, \mathrm{H}}, \mathrm{Hz}\right.$; $\left.\mathrm{CDCl}_{3}, \mathrm{rt}\right)$

\begin{tabular}{|c|c|c|c|c|c|c|c|c|c|c|}
\hline $\begin{array}{l}\text { Configuration } \\
\text { (compound) }\end{array}$ & $\begin{array}{l}\text { H-3eq } \\
\left(J_{3 \text { eq,3ax }}\right)\end{array}$ & $\begin{array}{l}\text { H-3ax } \\
\left(J_{3 a x, 4}\right)\end{array}$ & $\begin{array}{l}\mathrm{H}-4 \\
\left(J_{3 \mathrm{eq}, 4}\right)\end{array}$ & $\begin{array}{l}\mathrm{H}-5 \\
\left(J_{4,5}\right)\end{array}$ & $\begin{array}{l}\mathrm{H}-6 \\
\left(J_{5,6}\right)\end{array}$ & $\begin{array}{l}\mathrm{H}-7 \\
\left(J_{6,7}\right)\end{array}$ & $\begin{array}{l}\mathrm{H}-8 \\
\left(J_{7,8}\right)\end{array}$ & $\begin{array}{l}\mathrm{H}-9 \\
\left(J_{8,9}\right)\end{array}$ & $\begin{array}{l}\mathrm{NH}-5 \\
\left(J_{\mathrm{NH}, 5}\right)\end{array}$ & $\begin{array}{l}\mathrm{NH}-9 \\
\left(J_{\mathrm{NH}, 7}\right)\end{array}$ \\
\hline$\alpha$-D-glycero-D-galacto $(\alpha-64)$ & $\begin{array}{l}2.71 \\
(13.5)\end{array}$ & 2.11 & $\begin{array}{l}5.28 \\
(5.1)\end{array}$ & $\begin{array}{l}3.85 \\
(10.0)\end{array}$ & $\begin{array}{l}4.53 \\
(10.7)\end{array}$ & $\begin{array}{l}4.38 \\
(1.4)\end{array}$ & $\begin{array}{l}4.88 \\
(\sim 7)\end{array}$ & $\begin{array}{l}1.23 \\
(6.4)\end{array}$ & $\begin{array}{l}5.73 \\
(9.4)\end{array}$ & $\begin{array}{l}5.83 \\
(10.0)\end{array}$ \\
\hline$\beta$-D-glycero-D-galacto $(\beta-64)$ & $\begin{array}{l}2.55 \\
(13.3)\end{array}$ & $\begin{array}{l}1.80 \\
(11.0)\end{array}$ & $\begin{array}{l}5.66 \\
(5.1)\end{array}$ & $\begin{array}{l}3.45 \\
(10.6)\end{array}$ & $\begin{array}{l}4.34 \\
(10.5)\end{array}$ & $\begin{array}{l}4.40 \\
(\sim 1)\end{array}$ & $\begin{array}{l}4.86 \\
(\sim 7)\end{array}$ & $\begin{array}{l}1.21 \\
(6.5)\end{array}$ & $\begin{array}{l}5.94 \\
(8.4)\end{array}$ & $\begin{array}{l}6.88 \\
(10.0)\end{array}$ \\
\hline$\alpha$-L-glycero-D-galacto $(\alpha-62)$ & $\begin{array}{l}2.72 \\
(13.6)\end{array}$ & 2.07 & $\begin{array}{l}5.44 \\
(5.1)\end{array}$ & $\begin{array}{l}3.59 \\
(9.5)\end{array}$ & $\begin{array}{l}4.61 \\
(10.0)\end{array}$ & $\begin{array}{l}4.23 \\
(\sim 1)\end{array}$ & $\begin{array}{l}5.14 \\
(7.2)\end{array}$ & $\begin{array}{l}1.31 \\
(6.4)\end{array}$ & $\begin{array}{l}5.81 \\
(9.3)\end{array}$ & $\begin{array}{l}5.87 \\
(9.9)\end{array}$ \\
\hline$\beta$-L-glycero-D-galacto $(\beta-62)$ & $\begin{array}{l}2.61 \\
(13.2)\end{array}$ & $\begin{array}{l}1.77 \\
(11.2)\end{array}$ & $\begin{array}{l}5.82 \\
(5.0)\end{array}$ & $\begin{array}{l}3.21 \\
(10.2)\end{array}$ & $\begin{array}{l}4.53 \\
(10.3)\end{array}$ & $\begin{array}{l}4.29 \\
(\sim 1)\end{array}$ & $\begin{array}{l}5.10 \\
(7.0)\end{array}$ & $\begin{array}{l}1.17 \\
(6.4)\end{array}$ & $\begin{array}{l}5.99 \\
(7.6)\end{array}$ & $\begin{array}{l}6.73 \\
(9.7)\end{array}$ \\
\hline$\alpha$-D-glycero-L-altro $(\alpha-63)$ & $\begin{array}{l}2.39 \\
(13.2)\end{array}$ & $\begin{array}{l}1.94 \\
(12.7)\end{array}$ & $\begin{array}{l}5.18 \\
(5.0)\end{array}$ & $\begin{array}{l}4.42 \\
(10.3)\end{array}$ & $\begin{array}{l}3.69 \\
(10.9)\end{array}$ & $\begin{array}{l}4.06 \\
(\sim 1)\end{array}$ & $\begin{array}{l}5.81 \\
(\sim 1)\end{array}$ & $\begin{array}{l}1.19 \\
(6.4)\end{array}$ & $\begin{array}{l}5.86 \\
(9.0)\end{array}$ & $\begin{array}{l}6.38 \\
(9.2)\end{array}$ \\
\hline$\alpha$-L-glycero-L-altro $(\alpha-\mathbf{6 5})$ & $\begin{array}{l}2.48 \\
(13.3)\end{array}$ & 1.95 & $\begin{array}{l}5.21 \\
(4.9)\end{array}$ & $\begin{array}{l}4.14 \\
(10.4)\end{array}$ & $\begin{array}{l}3.83 \\
(11.0)\end{array}$ & $\begin{array}{l}4.59 \\
(2.5)\end{array}$ & $\begin{array}{l}5.01 \\
(5.0)\end{array}$ & $\begin{array}{l}1.29 \\
(6.4)\end{array}$ & $\begin{array}{l}6.11 \\
(9.4)\end{array}$ & $\begin{array}{l}6.40 \\
(9.7)\end{array}$ \\
\hline$\beta$-L-glycero-L-altro $(\beta-65)$ & $\begin{array}{l}2.65 \\
(13.4)\end{array}$ & 2.03 & $\begin{array}{l}5.05 \\
(4.8)\end{array}$ & $\begin{array}{l}4.07 \\
(10.5)\end{array}$ & $\begin{array}{l}4.15 \\
(9.7)\end{array}$ & $\begin{array}{l}4.53 \\
(\sim 2)\end{array}$ & $\begin{array}{l}4.89 \\
(6.8)\end{array}$ & $\begin{array}{l}1.19 \\
(6.3)\end{array}$ & $\begin{array}{l}6.25 \\
(8.8)\end{array}$ & $\begin{array}{l}6.77 \\
(9.8)\end{array}$ \\
\hline & $\mathrm{C}-1$ & $\mathrm{C}-2$ & $\mathrm{C}-3$ & $\mathrm{C}-4$ & $\mathrm{C}-5$ & $\mathrm{C}-6$ & $\mathrm{C}-7$ & C-8 & C-9 & \\
\hline$\alpha$-D-glycero-D-galacto $(\alpha-64)$ & & 96.5 & 36.2 & 68.3 & 50.6 & 72.5 & 50.6 & 69.5 & 16.8 & \\
\hline$\beta$-D-glycero-D-galacto $(\beta-64)$ & 166.7 & 96.8 & 36.8 & 67.1 & 51.7 & 70.6 & 50.6 & 69.8 & 16.8 & \\
\hline$\alpha$-L-glycero-D-galacto $(\alpha-62)$ & 167.9 & 96.5 & 36.2 & 67.5 & 51.5 & 73.4 & 52.5 & 70.5 & 17.1 & \\
\hline$\beta$-L-glycero-D-galacto $(\beta-62)$ & 167.2 & 96.6 & 36.6 & 66.3 & 52.6 & 72.0 & 51.8 & 70.2 & 17.5 & \\
\hline$\alpha$-D-glycero-L-altro $(\alpha-63)$ & 166.5 & 96.9 & 36.1 & 68.3 & 50.3 & 75.9 & 51.2 & 65.9 & 19.1 & \\
\hline$\alpha$-L-glycero-L-altro $(\alpha-65)$ & 166.7 & 97.3 & 36.7 & 68.7 & 50.7 & 73.9 & 50.0 & 68.8 & 16.2 & \\
\hline$\beta$-L-glycero-L-altro $(\beta-65)$ & & & 36.1 & 68.7 & 50.9 & 75.1 & 52.3 & 69.1 & 16.2 & \\
\hline
\end{tabular}
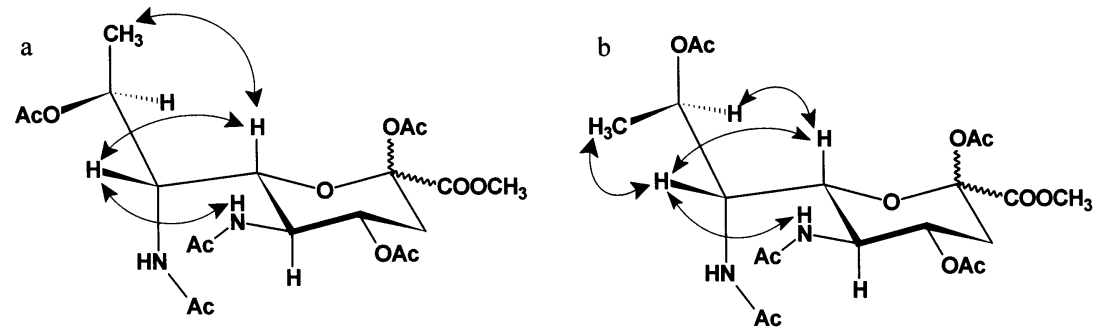

62 (L-glycero-D-galacto)

64 (D-glycero-D-galacto)
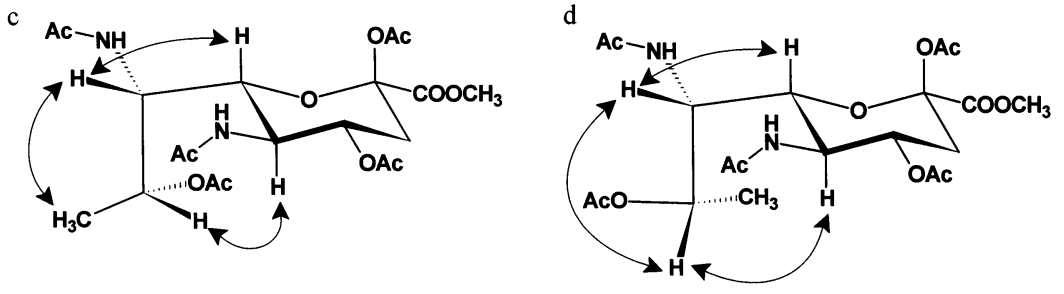

63 (D-glycero-L-altro)

65 (L-glycero-L-altro)

Fig. 1. NOE correlations and conformation of the side chain in methyl (5,7-diacetamido-2,4,8-tri- $O$-acetyl-3,5,7,9-tetradeoxynon2-ulopyranos)onates (62-65). Only correlations designated in Table 5 as strong are shown.

Small ${ }^{3} J_{\mathrm{H}-6, \mathrm{H}-7}$ coupling constant values (1$2.5 \mathrm{~Hz}$ ) were observed for all O-acetylated compounds, thus indicating the gauche orientation of H-6 and H-7 (Fig. 1). Relatively large ${ }^{3} J_{\mathrm{H}-7, \mathrm{H}-8}$ values of $\sim 7 \mathrm{~Hz}$ for 62 (L-glycero-D-galacto) and 64 (D-glycero-D-galacto) showed the trans-like orientation of $\mathrm{H}-7$ and $\mathrm{H}-8$ in the predominant conformer. Almost 
Table 5

NOE correlations for H-9, H-8, H-7 and NH-7 in methyl (5,7-diacetamido-2,4,8-tri-O-acetyl-3,5,7,9-tetradeoxynon-2ulopyranos)onates (relative intensity in parentheses; s, strong; m, medium; w, weak)

\begin{tabular}{|c|c|c|c|c|}
\hline $\begin{array}{l}\text { Configuration } \\
\text { (compound) }\end{array}$ & H-9 & $\mathrm{H}-8$ & $\mathrm{H}-7$ & NH-7 \\
\hline $\begin{array}{l}\text { D-glycero-D-galacto } \\
\text { (64) }\end{array}$ & $\begin{array}{l}\mathrm{H}-8 \text { (s), H-7 (s), NH-7 } \\
(\mathrm{m})\end{array}$ & $\mathrm{H}-7$ (w), H-6 (s), NH-7 (m) & $\begin{array}{l}\mathrm{H}-6 \text { (s), NH-5 (s), NH-7 } \\
\text { (m) }\end{array}$ & $\mathrm{H}-5(\mathrm{~m})$ \\
\hline $\begin{array}{l}\text { L-glycero-D-galacto } \\
\quad(62)\end{array}$ & $\begin{array}{l}\mathrm{H}-8(\mathrm{~s}), \mathrm{H}-7 \text { (m), H-6 } \\
(\mathrm{s})\end{array}$ & $\mathrm{H}-7$ (w), H-6 (m), NH-7 (m) & $\begin{array}{l}\mathrm{H}-6 \text { (s), NH-5 (s), NH-7 } \\
(\mathrm{m})\end{array}$ & $\mathrm{H}-5(\mathrm{~m})$ \\
\hline $\begin{array}{l}\text { L-glycero-L-altro } \\
\text { (65) }\end{array}$ & $\begin{array}{l}\mathrm{H}-8 \text { (s), H-7 (w), H-5 } \\
\text { (w) }\end{array}$ & H-7 (s), H-5 (s), NH-5 (w) & H-6 (s), NH-5 (w) & $\begin{array}{l}\mathrm{H}-9(\mathrm{~m}), \mathrm{H}-7 \\
(\mathrm{~m})\end{array}$ \\
\hline
\end{tabular}

the same large value $(5-7 \mathrm{~Hz}$, depending on the anomeric configuration) was observed for 65 (L-glycero-L-altro), whereas in 63 (D-glycero-L-altro) it was significantly smaller $(\sim 1$ $\mathrm{Hz}$ ).

Correlations between $\mathrm{H}-7$ and both $\mathrm{H}-6$ and $\mathrm{NH}-5$ in the L- and D-glycero-D-galacto isomers (62 and 64) that were revealed by a NOESY experiment defined the predominant rotamer around the $\mathrm{C}-6-\mathrm{C}-7$ bond (Table 5, Fig. 1(a) and (b)). This conformation was in agreement with a small ${ }^{3} J_{\mathrm{H}-6, \mathrm{H}-\mathrm{7}}$ value $(1-1.4$ $\mathrm{Hz}$ ). The NOESY spectra of both $\mathbf{6 2}$ and $\mathbf{6 4}$ showed only a weak $\mathrm{H}-8, \mathrm{H}-7$ correlation that, together with a relatively large ${ }^{3} J_{\mathrm{H}-7, \mathrm{H}-8}$ value $(\sim 7 \mathrm{~Hz})$, indicated the trans-like orientation of H-7 and H-8. Strong H-9,H-7 and medium H-9, NH-7 correlations for $\mathbf{6 4}$ showed a spatial proximity of $\mathrm{H}-9$ and $\mathrm{H}-7$, and a strong $\mathrm{H}-$ 8,H-6 correlation demonstrated that these protons are close to each other (Fig. 1(b)). In 62, $\mathrm{H}-9$ is more close to $\mathrm{H}-6$ than to $\mathrm{H}-7$ as followed from a stronger H-9,H-6 correlation compared to a H-9,H-7 correlation (Fig. 1(a)). Therefore, in 62 and $\mathbf{6 4}$, predominant are the trans, trans and trans, cis side-chain (C-7-C8-C-9) conformers, respectively.

An HMBC experiment optimized for a coupling constant of $8 \mathrm{~Hz}$ revealed a strong H-6,C-8 correlation for the D- and L-glyceroL-altro isomers (63 and $\mathbf{6 5}$ ), which corresponded to a ${ }^{3} J_{\mathrm{H}-6, \mathrm{C}-8}$ coupling constant of $>5 \mathrm{~Hz}$. This finding showed the trans-like orientation of H-6 and C-8 in the predominant rotamer around the $\mathrm{C}-6-\mathrm{C}-7$ bond, ${ }^{32}$ which was confirmed by a strong H-7,H-6 correlation with no H-8,H-6 and H-9,H-6 cor- relations in the NOESY spectra of $\mathbf{6 3}$ and $\mathbf{6 5}$. The most populated rotamers around the C$7-\mathrm{C}-8$ bond are characterized by strong $\mathrm{H}-$ 9,H-7 and H-8,H-5 correlations for 63 and strong $\mathrm{H}-8, \mathrm{H}-5$ and weak $\mathrm{H}-9, \mathrm{H}-5$ correlations for 65 (Table 5, Fig. 1(c) and (d)). The presence of an intense $\mathrm{H}-7, \mathrm{H}-8$ correlation peak in the NOESY spectrum of $\mathbf{6 5}$ seems to be inconsistent with a relatively large ${ }^{3} J_{\mathrm{H}-7, \mathrm{H}-8}$ value $(5-7 \mathrm{~Hz})$. This contradiction could be accounted for by a significant contribution of rotamers with a small $\mathrm{H}-7-\mathrm{C}-7-\mathrm{C}-8-\mathrm{H}-8$ dihedral angle. The predominant conformers of $\mathbf{6 3}$ and 64 have cis,trans and cis,cis side-chain orientation, respectively.

\section{Experimental}

NMR spectra were recorded on Bruker DRX-500 and Bruker AM-300 instruments. Spectra of hexose derivatives were measured for solutions in $\mathrm{CDCl}_{3}$ unless otherwise stated, and ${ }^{1} \mathrm{H}$ NMR chemical shifts were referenced to a residual solvent signal. Spectra of 5,7-diacetamido-3,5,7,9-tetradeoxynon-2-ulosonic acids were measured for solutions in $\mathrm{D}_{2} \mathrm{O}$ using acetone $\left(\delta_{\mathrm{H}} 2.225, \delta_{\mathrm{C}} 31.45\right)$ as internal standard. Sodium salts were obtained by passing aqueous solutions of the acids through a short column of Amberlite IR-420 $\left(\mathrm{Na}^{+}\right.$ form). A mixing time of 300 or $900 \mathrm{~ms}$ was used in NOESY experiments with methyl (5,7diacetamido-2,4,8 - tri- $O$-acetyl-3,5,7,9 - tetradeoxynon-2-ulopyranos)onates.

Melting points were determined with a Kofler apparatus and are uncorrected. Optical 
rotation values were measured on a JASCO DIP-360 polarimeter at $22 \pm 2{ }^{\circ} \mathrm{C}$. TLC was performed on Kieselgel $60 \mathrm{~F}_{254}$ plates (E. Merck), and visualization was accomplished using UV light or by charring with $10 \%$ $\mathrm{H}_{2} \mathrm{SO}_{4}$. Column chromatography was carried out on Silpearl silica gel (Chemapol) in a medium pressure mode. Preparative reversedphase $\mathrm{C}_{18}$ HPLC was performed on a column $(250 \times 24 \mathrm{~mm})$ of $7.5 \mu \mathrm{m}$ Silasorb $\mathrm{C}_{18}(\mathrm{Czech}$ Republic) in $0.05 \%$ aq $\mathrm{CF}_{3} \mathrm{CO}_{2} \mathrm{H}$ at $10 \mathrm{~mL} /$ min using a Knauer 98.00 refractometer for monitoring. ESIMS data were recorded with a Micromass Quattro system. All reactions involving air- or moisture-sensitive reagents were carried out in dry solvents under dry argon.

Benzyl 3,4-di-O-benzoyl- $\beta$-L-rhamnopyranoside (2), benzyl 2,4-di-O-benzoyl- $\beta$-Lrhamnopyranoside (3), and benzyl 2,3-di-Obenzoyl- $\beta$-L-rhamnopyranoside (4). - A mixture of 1 (7.8 g, $21 \mathrm{mmol})$ and $\mathrm{Bu}_{2} \mathrm{SnO}(5.49 \mathrm{~g}$, $22 \mathrm{mmol})$ in benzene $(150 \mathrm{~mL})$ was boiled with azeotropic removal of water for $2 \mathrm{~h}$, whereupon a crystalline precipitate of the stannylene derivative formed. Tetrabutylammonium bromide $(7.08 \mathrm{~g}, 22 \mathrm{mmol})$ and benzyl bromide ( $5 \mathrm{~mL}, 42 \mathrm{mmol}$ ) were added, and the mixture was boiled under reflux for $4 \mathrm{~h}$. After cooling, the solution was washed thoroughly with water and concentrated. Column chromatography of the residue (95:5 toluene-EtOAc) gave a mixture of $2-4(8.95 \mathrm{~g}, 92 \%)$ in ratios of $\sim 4: 3: 1$, which was used in the next step without separation.

A small portion of the above mixture was subjected to column chromatography $(85: 15$ light petroleum-EtOAc) to give, in order of elution, pure compounds $\mathbf{2}, \mathbf{3}$, and $\mathbf{4}$.

3,4-Dibenzoate 2: mp $172-174{ }^{\circ} \mathrm{C}$ (EtOAchexane); $[\alpha]_{\mathrm{D}}+129^{\circ}$ (c 2). ${ }^{1} \mathrm{H}$ NMR: $\delta, 1.42$ (d, $3 \mathrm{H}, J_{5,6} 6.2 \mathrm{~Hz}, \mathrm{H}-6$ ), 2.53 (br. s, $1 \mathrm{H}$, $\mathrm{OH}), 3.73$ (dq, $1 \mathrm{H}, \mathrm{H}-5), 4.37$ (dd, $1 \mathrm{H}, J_{2,3}$ $3.2 \mathrm{~Hz}, \mathrm{H}-2), 4.74,4.99\left(2 \mathrm{~d}, 2 \mathrm{H}, J_{\text {gem }} 11.9\right.$ $\left.\mathrm{Hz}, \mathrm{PhCH}_{2}\right), 4.75$ (d, $\left.1 \mathrm{H}, J_{1,2} 1.1 \mathrm{~Hz}, \mathrm{H}-1\right)$, $5.28\left(\mathrm{dd}, 1 \mathrm{H}, J_{3,4} 10.8 \mathrm{~Hz}, \mathrm{H}-3\right), 5.67(\mathrm{t}, 1 \mathrm{H}$, $\left.J_{4,5} 9.7 \mathrm{~Hz}, \mathrm{H}-4\right), 7.30-8.04(\mathrm{~m}, 15 \mathrm{H}, 3 \mathrm{Ph})$. Anal. Calcd for $\mathrm{C}_{27} \mathrm{H}_{26} \mathrm{O}_{7}: \mathrm{C}, 70.12 ; \mathrm{H}, 5.67$. Found: C, 69.98; H, 5.59.
2,4-Dibenzoate 3: $\mathrm{mp} 123-125^{\circ} \mathrm{C}$ (EtOAchexane); $[\alpha]_{\mathrm{D}}+91^{\circ}$ (c 2). ${ }^{1} \mathrm{H}$ NMR: $\delta, 1.44$ (d, $\left.3 \mathrm{H}, J_{5,6} 6.1, \mathrm{H}-6\right), 3.71$ (dq, $\left.1 \mathrm{H}, \mathrm{H}-5\right)$, $4.02\left(\mathrm{dd}, 1 \mathrm{H}, J_{3.4} 9.8 \mathrm{~Hz}, \mathrm{H}-3\right), 4.70,4.93$ (2 $\left.\mathrm{d}, 2 \mathrm{H}, J_{\text {gem }} 12.4 \mathrm{~Hz}, \mathrm{PhCH}_{2}\right), 4.73(\mathrm{~s}, 1 \mathrm{H}$, $\mathrm{H}-1), 5.23$ (t, $\left.1 \mathrm{H}, J_{4,5} 9.6 \mathrm{~Hz}, \mathrm{H}-4\right), 5.72$ (d, 1 $\left.\mathrm{H}, J_{2,3} 3.6 \mathrm{~Hz}, \mathrm{H}-2\right), 7.28-8.21(\mathrm{~m}, 15 \mathrm{H}, 3$ $\mathrm{Ph}$ ). Anal. Calcd for $\mathrm{C}_{27} \mathrm{H}_{26} \mathrm{O}_{7}: \mathrm{C}, 70.12 ; \mathrm{H}$, 5.67. Found: C, 70.13; H, 5.61.

2,3-Dibenzoate 4 had $\mathrm{mp} \quad 135-137^{\circ} \mathrm{C}$ (EtOAc-hexane), $[\alpha]_{\mathrm{D}}+82^{\circ}$ (c 1.7). ${ }^{1} \mathrm{H}$ NMR: $\delta, 1.54\left(\mathrm{~d}, 3 \mathrm{H}, J_{5,6} 6.1, \mathrm{H}-6\right), 2.43(\mathrm{~d}$, $\left.1 \mathrm{H}, J_{4, \mathrm{OH}} 4.6 \mathrm{~Hz}, \mathrm{OH}\right), 3.52(\mathrm{dq}, 1 \mathrm{H}, \mathrm{H}-5)$, $3.92\left(\mathrm{dt}, 1 \mathrm{H}, J_{4,5} 9.2 \mathrm{~Hz}, \mathrm{H}-4\right), 4.71,4.92(2 \mathrm{~d}$, $\left.2 \mathrm{H}, J_{\text {gem }} 12.3 \mathrm{~Hz}, \mathrm{PhCH}_{2}\right), 4.78$ (s, $\left.1 \mathrm{H}, \mathrm{H}-1\right)$, 5.17 (dd, $\left.1 \mathrm{H}, J_{3,4} 9.7 \mathrm{~Hz}, \mathrm{H}-3\right), 5.83(\mathrm{~d}, 1 \mathrm{H}$, $\left.J_{2,3} 3.1 \mathrm{~Hz}, \mathrm{H}-2\right), 7.29-8.15(\mathrm{~m}, 15 \mathrm{H}, 3 \mathrm{Ph})$. Anal. Calcd for $\mathrm{C}_{27} \mathrm{H}_{26} \mathrm{O}_{7}: \mathrm{C}, 70.12 ; \mathrm{H}, 5.67$. Found: C, 69.71; H, 5.65.

Benzyl $\beta$-L-rhamnopyranoside (5). - A solution of the above mixture of 2-4 (9.44 g, 20.4 $\mathrm{mmol})$ in $\mathrm{MeOH}(50 \mathrm{~mL})$ was treated with 2 $\mathrm{M} \mathrm{CH}{ }_{3} \mathrm{ONa}(1 \mathrm{~mL})$ for $5 \mathrm{~h}$ at $40{ }^{\circ} \mathrm{C}$. The mixture was neutralized with Amberlite IR$120\left(\mathrm{H}^{+}\right)$, filtered, and the filtrate was concentrated. The residue was chromatographed (1:1 toluene-acetone) to yield 5 (4.40 g, 85\%): mp $107-108^{\circ} \mathrm{C}$ (EtOAc-hexane); $[\alpha]_{\mathrm{D}}+103^{\circ}(c$ 1.7). ${ }^{1} \mathrm{H} \mathrm{NMR}\left(\mathrm{CDCl}_{3}+\mathrm{D}_{2} \mathrm{O}\right): \delta, 1.33(\mathrm{~d}, 3$ $\left.\mathrm{H}, J_{5,6} 6.0 \mathrm{~Hz}, \mathrm{H}-6\right), 3.16$ (dq, $\left.1 \mathrm{H}, \mathrm{H}-5\right), 3.34$ $\left(\mathrm{dd}, 1 \mathrm{H}, J_{3,4} 9.5 \mathrm{~Hz}, \mathrm{H}-3\right), 3.42\left(\mathrm{t}, 1 \mathrm{H}, J_{4,5}\right.$ $8.9 \mathrm{~Hz}, \mathrm{H}-4), 3.89$ (d, $\left.1 \mathrm{H}, J_{2,3} 3.0 \mathrm{~Hz}, \mathrm{H}-2\right)$, $4.36(\mathrm{~s}, 1 \mathrm{H}, \mathrm{H}-1), 4.55,4.84\left(2 \mathrm{~d}, 2 \mathrm{H}, J_{\text {gem }}\right.$ $\left.11.9 \mathrm{~Hz}, \mathrm{PhCH}_{2}\right), 7.23-7.34(\mathrm{~m}, 5 \mathrm{H}, \mathrm{Ph})$. Anal. Calcd for $\mathrm{C}_{13} \mathrm{H}_{18} \mathrm{O}_{5}$ : C, 61.40; H, 7.14. Found: C, 61.43; H, 7.04.

Benzyl 2,4-di-O-acetyl- $\beta$-L-rhamnopyranoside (6). $-p$-Toluenesulfonic acid monohydrate (190 mg, $1 \mathrm{mmol}$ ) was added to a solution of $\mathbf{5}(8.86 \mathrm{~g}, 34.9 \mathrm{mmol})$ and trimethyl orthoacetate $(13.2 \mathrm{~mL}, 105 \mathrm{mmol})$ in $\mathrm{CH}_{3} \mathrm{CN}(100 \mathrm{~mL})$, and the mixture was stirred for $30 \mathrm{~min}$. Py $(5 \mathrm{~mL})$ was added, and the solvent was evaporated. The residue was dissolved in py $(60 \mathrm{~mL})$ and treated with $\mathrm{Ac}_{2} \mathrm{O}$ $(20 \mathrm{~mL})$ overnight. The excess of $\mathrm{Ac}_{2} \mathrm{O}$ was destroyed by adding water at $0{ }^{\circ} \mathrm{C}$, the resulting mixture was diluted with $\mathrm{CHCl}_{3}$, washed successively with water, $\mathrm{M} \mathrm{HCl}$, satd aq $\mathrm{NaHCO}_{3}$, and water. The solvent was evaporated, and the residue was treated with $80 \%$ 
aq $\mathrm{AcOH}(50 \mathrm{~mL})$ for $15 \mathrm{~min}$. The mixture was concentrated, and residual $\mathrm{AcOH}$ was coevaporated with toluene. Column chromatography of the residue (1:1 tolueneEtOAc) gave $6(8.68 \mathrm{~g}, 73.5 \%): \mathrm{mp} 141-143{ }^{\circ} \mathrm{C}$ (EtOAc-hexane); $[\alpha]_{\mathrm{D}}+64.5^{\circ}\left(c\right.$ 1.8). ${ }^{1} \mathrm{H}$ NMR: $\delta, 1.32\left(\mathrm{~d}, 3 \mathrm{H}, J_{5,6} 6.2 \mathrm{~Hz}, \mathrm{H}-6\right), 2.12$, $2.21\left(2 \mathrm{~s}, 6 \mathrm{H}, 2 \mathrm{CH}_{3} \mathrm{CO}\right), 2.48\left(\mathrm{~d}, 1 \mathrm{H}, J_{3, \mathrm{OH}}\right.$ $7.3 \mathrm{~Hz}, \mathrm{OH}), 3.46$ (dq, $1 \mathrm{H}, \mathrm{H}-5), 3.75$ (ddd, 1 $\left.\mathrm{H}, J_{3,4} 10.0 \mathrm{~Hz}, \mathrm{H}-3\right), 4.57$ (s, $\left.1 \mathrm{H}, \mathrm{H}-1\right), 4.65$, $4.90\left(2 \mathrm{~d}, 2 \mathrm{H}, J_{\text {gem }} 12.0 \mathrm{~Hz}, \mathrm{PhCH}_{2}\right), 4.84(\mathrm{t}$, $\left.1 \mathrm{H}, J_{4,5} 9.5 \mathrm{~Hz}, \mathrm{H}-4\right), 5.43$ (d, $1 \mathrm{H}, J_{2,3} 3.5$ $\mathrm{Hz}, \mathrm{H}-2)$, 7.29-7.38 (m, 5 H, Ph). Anal. Calcd for $\mathrm{C}_{17} \mathrm{H}_{22} \mathrm{O}_{7}$ : C, 60.34; $\mathrm{H}, 6.55$. Found: $\mathrm{C}$, 60.43; H, 6.63.

Benzyl 3,4-anhydro-6-deoxy- $\beta$-L-altropyranoside (8). - A solution of trifluoromethanesulfonic anhydride $\left(\mathrm{Tf}_{2} \mathrm{O}\right)(8.4 \mathrm{~mL}, 50 \mathrm{mmol})$ in $\mathrm{CH}_{2} \mathrm{Cl}_{2}(10 \mathrm{~mL})$ was added dropwise at $0{ }^{\circ} \mathrm{C}$ to a solution of $6(10.2 \mathrm{~g}, 30.2 \mathrm{mmol})$ and py $(7.27 \mathrm{~mL}, 90 \mathrm{mmol})$ in $\mathrm{CH}_{2} \mathrm{Cl}_{2}(100 \mathrm{~mL})$, and the mixture was stirred at the same temperature for $45 \mathrm{~min}$. The solution was diluted with $\mathrm{CHCl}_{3}$, washed successively with ice-cold water, $\mathrm{M} \mathrm{HCl}$, and water, and concentrated. The crude triflate 7 was dissolved in $\mathrm{MeOH}$ $(70 \mathrm{~mL})$ and treated with $2 \mathrm{M} \mathrm{CH}_{3} \mathrm{ONa}(30$ $\mathrm{mL}$ ) for $30 \mathrm{~min}$ at $\mathrm{rt}$. The solution was neutralised with $\mathrm{AcOH}$, taken to dryness, and the residue was distributed between water and $\mathrm{CHCl}_{3}$. The organic layer was separated, and the water layer was extracted twice with $\mathrm{CHCl}_{3}$. The combined organic solution was concentrated, and the residue was subjected to column chromatography (3:2 toluene-EtOAc) to give $8(5.66 \mathrm{~g}, 79 \%)$ as a syrup: $[\alpha]_{\mathrm{D}}+87^{\circ}$ (c 2.6). ${ }^{1} \mathrm{H}$ NMR: $\delta 1.47\left(\mathrm{~d}, 3 \mathrm{H}, J_{5,6} 7.0 \mathrm{~Hz}\right.$, H-6), 2.63 (br, s, 1 H, OH), 3.04 (d, 1 H, H-4), $3.44\left(\mathrm{dd}, 1 \mathrm{H}, J_{3,4} 3.9 \mathrm{~Hz}, \mathrm{H}-3\right), 4.02(\mathrm{t}, 1 \mathrm{H}$, $\left.J_{2,3} 1.7 \mathrm{~Hz}, \mathrm{H}-2\right), 4.07$ (q, $\left.1 \mathrm{H}, \mathrm{H}-5\right), 4.54$ (d 1 $\left.\mathrm{H}, J_{1,2} 1.6 \mathrm{~Hz}, \mathrm{H}-1\right), 4.58,4.89\left(2 \mathrm{~d}, 2 \mathrm{H}, J_{\text {gem }}\right.$ $\left.11.9 \mathrm{~Hz}, \mathrm{PhCH}_{2}\right), 7.27-7.42(\mathrm{~m}, 5 \mathrm{H}, \mathrm{Ph})$. Anal. Calcd for $\mathrm{C}_{13} \mathrm{H}_{16} \mathrm{O}_{4}$ : C, 66.08; H, 6.83. Found: C, 66.13; H, 6.95.

Conventional acetylation of $\mathbf{8}$ with $\mathrm{Ac}_{2} \mathrm{O}$ in py afforded 2-acetate 9. ${ }^{1} \mathrm{H}$ NMR: $\delta 1.50(\mathrm{~d}, 3$ $\left.\mathrm{H}, J_{5,6} 7.5 \mathrm{~Hz}, \mathrm{H}-6\right), 2.17$ (s, $\left.3 \mathrm{H}, \mathrm{CH}_{3} \mathrm{CO}\right)$, 3.07 (d, $1 \mathrm{H}, \mathrm{H}-4), 3.39\left(\mathrm{dd}, 1 \mathrm{H}, J_{3,4} 4.0 \mathrm{~Hz}\right.$, H-3), 4.10 (q, $1 \mathrm{H}, \mathrm{H}-5), 4.57,4.86(2 \mathrm{~d}, 2 \mathrm{H}$, $\left.J_{\text {gem }} 13.2 \mathrm{~Hz}, \mathrm{PhCH}_{2}\right), 4.64\left(\mathrm{~d}, 1 \mathrm{H}, J_{1,2} 2.1\right.$ $\mathrm{Hz}, \mathrm{H}-1), 5.25$ (t, $\left.1 \mathrm{H}, J_{2,3} 1.8 \mathrm{~Hz}, \mathrm{H}-2\right)$, 7.25-7.38 (m, $5 \mathrm{H}, \mathrm{Ph})$.
Benzyl 3,4-anhydro-2-azido-2,6-dideoxy- $\beta$ L-allopyranoside (11). - Compound 8 (5.66 g, $24 \mathrm{mmol})$ was treated with $\mathrm{Tf}_{2} \mathrm{O}(6.71 \mathrm{~mL}, 40$ $\mathrm{mmol})$ in the presence of py $(5.82 \mathrm{~mL}, 72$ $\mathrm{mmol})$ in $\mathrm{CH}_{2} \mathrm{Cl}_{2}(75 \mathrm{~mL})$ as described in the preparation of 7 . The crude triflate $\mathbf{1 0} \mathrm{ob}-$ tained was dissolved in DMF $(50 \mathrm{~mL})$, sodium azide $(7.8 \mathrm{~g}, 120 \mathrm{mmol})$ was added, and the mixture was stirred for $1 \mathrm{~h}$ at $\mathrm{rt}$. The mixture was diluted with EtOAc, washed thoroughly with water, dried with $\mathrm{MgSO}_{4}$ and concentrated. Column chromatography of the residue (85:15 light petroleum-EtOAc) gave 11 (5.22 g, 83\%): $\mathrm{mp} 52-54{ }^{\circ} \mathrm{C}$ (hexane); $[\alpha]_{\mathrm{D}}$ $+78^{\circ}\left(c\right.$ 1.1). ${ }^{1} \mathrm{H}$ NMR: $\delta 1.44\left(\mathrm{~d}, 3 \mathrm{H}, J_{5,6} 6.8\right.$ $\mathrm{Hz}, \mathrm{H}-6), 3.17$ (d, $1 \mathrm{H}, \mathrm{H}-4), 3.45$ (dd, $1 \mathrm{H}$, $\left.J_{3,4} 4.2 \mathrm{~Hz}, \mathrm{H}-3\right), 3.69\left(\mathrm{dd}, 1 \mathrm{H}, J_{2,3} 2.2 \mathrm{~Hz}\right.$, H-2), 4.08 (q, $1 \mathrm{H}, \mathrm{H}-5), 4.58$ (d, $1 \mathrm{H}, J_{1,2} 7.6$ $\mathrm{Hz}, \mathrm{H}-1), 4.62,4.87$ (2 d, $2 \mathrm{H}, J_{\text {gem }} 11.4 \mathrm{~Hz}$, $\left.\mathrm{PhCH}_{2}\right), 7.29-7.41(\mathrm{~m}, 5 \mathrm{H}, \mathrm{Ph})$. Anal. Calcd for $\mathrm{C}_{13} \mathrm{H}_{15} \mathrm{~N}_{3} \mathrm{O}_{3}$ : C, 59.76; H, 5.79; N, 16.08. Found: C, 59.64; H, 5.80; N, 16.00.

Benzyl 2,4-diazido-2,4,6-trideoxy- $\beta$-L-gulopyranoside (12). - A solution of sodium azide (6.7 $\mathrm{g}, 103 \mathrm{mmol})$ and ammonium chloride (5.51 g, $103 \mathrm{mmol})$ in water $(25 \mathrm{~mL})$ was added to a solution of 11 (5.38 g, $20.6 \mathrm{mmol})$ in $\mathrm{EtOH}(100 \mathrm{~mL})$. The mixture was boiled under reflux for $7 \mathrm{~h}$, EtOH was distilled off, and the remaining aqueous solution was extracted three times with $\mathrm{CHCl}_{3}$. The combined extract was concentrated, and the residue was subjected to column chromatography (92:8 toluene-EtOAc) to yield $12(5.40 \mathrm{~g}, 86 \%)$ as a syrup: $[\alpha]_{\mathrm{D}}+63^{\circ}(c)$ ). ${ }^{1} \mathrm{H}$ NMR: $\delta 1.37(\mathrm{~d}, 3$ $\left.\mathrm{H}, J_{5,6} 6.5 \mathrm{~Hz}, \mathrm{H}-6\right), 2.47$ (s, $\left.1 \mathrm{H}, \mathrm{OH}\right), 3.47$ $\left(\mathrm{dd}, 1 \mathrm{H}, J_{4,5} 1.3 \mathrm{~Hz}, J_{3,4} 3.4 \mathrm{~Hz}, \mathrm{H}-4\right), 3.66$ $\left(\mathrm{dd}, 1 \mathrm{H}, J_{2,3} 3.1 \mathrm{~Hz}, \mathrm{H}-2\right), 4.14(\mathrm{~m}, 2 \mathrm{H}$, $\mathrm{H}-3,5), 4.67,4.96\left(2 \mathrm{~d}, 2 \mathrm{H}, J_{\text {gem }} 11.8 \mathrm{~Hz}\right.$, $\mathrm{PhCH}_{2}$ ), 4.77 (d, $\left.1 \mathrm{H}, J_{1,2} 8.1 \mathrm{~Hz}, \mathrm{H}-1\right)$, 7.30-7.41 (m, 5 H, Ph). Anal. Calcd for $\mathrm{C}_{13} \mathrm{H}_{16} \mathrm{~N}_{6} \mathrm{O}_{3}$ : C, 51.31; H, 5.30; N, 27.62. Found: C, 51.44; H, 5.35; N, 27.63.

Conventional acetylation of $\mathbf{1 2}$ with $\mathrm{Ac}_{2} \mathrm{O}$ in py gave 3-acetate 13. ${ }^{1} \mathrm{H}$ NMR: $\delta 1.38(\mathrm{~d}, 3$ $\left.\mathrm{H}, J_{5,6} 6.5 \mathrm{~Hz}, \mathrm{H}-6\right), 2.05$ (s, $\left.3 \mathrm{H}, \mathrm{CH}_{3} \mathrm{CO}\right)$, 3.48 (dd, $\left.1 \mathrm{H}, J_{4,5} 1.7 \mathrm{~Hz}, \mathrm{H}-4\right), 3.69$ (dd, $1 \mathrm{H}$, $\left.J_{2,3} 3.4 \mathrm{~Hz}, \mathrm{H}-2\right), 4.03$ (dq, $\left.1 \mathrm{H}, \mathrm{H}-5\right), 4.69$, $4.96\left(2 \mathrm{~d}, 2 \mathrm{H}, J_{\text {gem }} 11.8 \mathrm{~Hz}, \mathrm{PhCH}_{2}\right), 4.79(\mathrm{~d}$, $\left.1 \mathrm{H}, J_{1,2} 8.1 \mathrm{~Hz}, \mathrm{H}-1\right), 5.33\left(\mathrm{t}, 1 \mathrm{H}, J_{3,4} 3.5 \mathrm{~Hz}\right.$, $\mathrm{H}-3), 7.30-7.42$ (m, $5 \mathrm{H}, \mathrm{Ph})$. 
Benzyl 2,4-diacetamido-2,4,6-trideoxy- $\beta$-Lgulopyranoside (14). $-20 \% \quad \mathrm{Pd}(\mathrm{OH})_{2} / \mathrm{C} \quad(950$ $\mathrm{mg}$ ) was added to a solution of 12 (3.77 g, $12.4 \mathrm{mmol})$ in $\mathrm{MeOH}(60 \mathrm{~mL})$, and the mixture was stirred vigorously in a hydrogen atmosphere for $2.5 \mathrm{~h}$ at $30-32{ }^{\circ} \mathrm{C}$. The catalyst was filtered through Celite, washed with $\mathrm{MeOH}$, and the combined filtrate and washings were concentrated to a volume of $\sim 20$ $\mathrm{mL}$. $\mathrm{Ac}_{2} \mathrm{O}(6 \mathrm{~mL})$ was added, and the solution was kept for $1 \mathrm{~h}$ and evaporated. Residual $\mathrm{Ac}_{2} \mathrm{O}$ was removed by coevaporation with toluene, and the residue was chromatographed (95:5 chloroform-MeOH) to give 14 (3.48 g, $84 \%)$ as an amorphous solid: $[\alpha]_{\mathrm{D}}+46.5^{\circ}(c$ 3). ${ }^{1} \mathrm{H} \mathrm{NMR}\left(\mathrm{CDCl}_{3}+\mathrm{D}_{2} \mathrm{O}\right): \delta 1.17(\mathrm{~d}, 3 \mathrm{H}$, $\left.J_{5,6} 6.5 \mathrm{~Hz}, \mathrm{H}-6\right), 1.96,2.02(2 \mathrm{~s}, 6 \mathrm{H}$, $\left.\mathrm{CH}_{3} \mathrm{CO}\right), 3.87\left(\mathrm{t}, 1 \mathrm{H}, J_{3,4} 3.2 \mathrm{~Hz}, \mathrm{H}-3\right), 3.98$ $\left(\mathrm{dd}, 1 \mathrm{H}, J_{4,5} 1.5 \mathrm{~Hz}, \mathrm{H}-4\right), 4.05$ (dd, $1 \mathrm{H}, J_{2,3}$ $3.4 \mathrm{~Hz}, \mathrm{H}-2), 4.20$ (dq, $1 \mathrm{H}, \mathrm{H}-5), 4.56,4.86$ (2 d, $\left.2 \mathrm{H}, J_{\text {gem }} 12.5 \mathrm{~Hz}, \mathrm{PhCH}_{2}\right), 4.58(\mathrm{~d}, 1 \mathrm{H}$, $\left.J_{1,2} 8.6 \mathrm{~Hz}, \mathrm{H}-1\right), 7.28-7.37(\mathrm{~m}, 5 \mathrm{H}, \mathrm{Ph})$. Anal. Calcd for $\mathrm{C}_{17} \mathrm{H}_{24} \mathrm{~N}_{2} \mathrm{O}_{5} 0.5 \mathrm{H}_{2} \mathrm{O}: \mathrm{C}, 59.11$; H, 7.29; N, 8.11. Found: C, 59.28; H, 7.36; N, 8.45 .

2,4-Diacetamido-2,4,6-trideoxy-L-gulopyranose (15).— A solution of 14 (4.45 g, 13.2 $\mathrm{mmol})$ in $\mathrm{MeOH}(60 \mathrm{~mL})$ was stirred with $20 \% \mathrm{Pd}(\mathrm{OH})_{2} / \mathrm{C}(1 \mathrm{~g})$ under hydrogen for $4 \mathrm{~h}$ at $32-34{ }^{\circ} \mathrm{C}$, filtered through Celite, (Caution: Extreme fire hazard) and concentrated. Column chromatography of the residue (94:6 $\left.\mathrm{CHCl}_{3}-\mathrm{MeOH}\right)$ gave $15(3.20 \mathrm{~g}, 94 \%)$ : $\mathrm{mp}$ $144-146^{\circ} \mathrm{C} \quad(\mathrm{MeOH}-$ ether $) ;[\alpha]_{\mathrm{D}}+6.3^{\circ} \rightarrow$ $+78^{\circ}\left(c\right.$ 1.6, MeOH). ${ }^{1} \mathrm{H}$ NMR $\left(\mathrm{D}_{2} \mathrm{O}\right): \mathbf{1 5} \alpha, \delta$ $1.16\left(\mathrm{~d}, 3 \mathrm{H}^{\dagger}, J_{5,6} 6.6 \mathrm{~Hz}, \mathrm{H}-6\right), 2.06,2.07$ (2 s, $\left.6 \mathrm{H}, 2 \mathrm{CH}_{3} \mathrm{CO}\right), 3.91$ (t, $\left.1 \mathrm{H}, J_{3,4} 3.8 \mathrm{~Hz}, \mathrm{H}-3\right)$, $3.95\left(\mathrm{dd}, 1 \mathrm{H}, J_{4,5} 1.7 \mathrm{~Hz}, \mathrm{H}-4\right), 4.11(\mathrm{t}, 1 \mathrm{H}$, $\left.J_{2,3} 3.5 \mathrm{~Hz}, \mathrm{H}-2\right), 4.62$ (dq, $\left.1 \mathrm{H}, \mathrm{H}-5\right), 5.15$ (d, $\left.1 \mathrm{H}, J_{1,2} 4.0 \mathrm{~Hz}, \mathrm{H}-1\right) ; \mathbf{1 5 \beta}, \delta 1.18\left(\mathrm{~d}, 3 \mathrm{H}^{*}\right.$, $\left.J_{5,6} 6.5 \mathrm{~Hz}, \mathrm{H}-6\right), 2.04,2.08(2 \mathrm{~s}, 6 \mathrm{H}, 2$ $\left.\mathrm{CH}_{3} \mathrm{CO}\right), 3.85$ (dd, $\left.1 \mathrm{H}, J_{2,3} 3.2 \mathrm{~Hz}, \mathrm{H}-2\right), 3.87$ $\left(\mathrm{dd}, 1 \mathrm{H}, J_{4,5} 1.6 \mathrm{~Hz}, \mathrm{H}-4\right), 3.94\left(\mathrm{t}, 1 \mathrm{H}, J_{3,4}\right.$ $3.4 \mathrm{~Hz}, \mathrm{H}-3), 4.29$ (dq, $1 \mathrm{H}, \mathrm{H}-5), 4.94$ (d, 1 $\left.\mathrm{H}, J_{1,2} 8.9 \mathrm{~Hz}, \mathrm{H}-1\right)$. The ratio $\mathbf{1 5 \alpha}: \mathbf{1 5} \boldsymbol{\beta} \approx 1: 5$. Anal. Calcd for $\mathrm{C}_{10} \mathrm{H}_{18} \mathrm{~N}_{2} \mathrm{O}_{5} \cdot 0.25 \mathrm{H}_{2} \mathrm{O}: \mathrm{C}$, 47.60; H, 7.39; N, 11.10. Found: C, 47.59; H, $7.50 ; \mathrm{N}, 11.49$.

\footnotetext{
$\dagger$ Integral intensities of signals for the compounds 15, 32, and $\mathbf{4 8}$ are given within anomeric series.
}

Benzyl 2-azido-3-O-benzyl-2-deoxy- $\beta$-Dmannopyranoside (17). - Pyridinium perchlorate $(1.14 \mathrm{~g}, 6.34 \mathrm{mmol})$ was added to a solution of 16 (3.00 g, $6.34 \mathrm{mmol})$ in $90 \% \mathrm{aq}$ $\mathrm{CH}_{3} \mathrm{CN}(30 \mathrm{~mL})$, and the mixture was heated at $80^{\circ} \mathrm{C}$ for $4 \mathrm{~h}$. Py $(0.5 \mathrm{~mL})$ was added, and the solvent was evaporated. The residue was distributed between water $(50 \mathrm{~mL})$ and $\mathrm{CHCl}_{3}$ $(50 \mathrm{~mL})$, the organic layer was separated, and the water layer was extracted with $\mathrm{CHCl}_{3}$ $(3 \times 50 \mathrm{~mL})$. The combined extract was concentrated, and the residue was subjected to column chromatography (3:2 toluene-EtOAc) to give $17(2.37 \mathrm{~g}, 97 \%)$ as a syrup: $[\alpha]_{\mathrm{D}}$ $-106^{\circ}\left(c 1, \mathrm{CHCl}_{3}\right) .{ }^{1} \mathrm{H}$ NMR: $\delta 3.26$ (ddd, 1 H, H-5), 3.46 (dd, $\left.1 \mathrm{H}, J_{3,4} 9.2 \mathrm{~Hz}, \mathrm{H}-3\right), 3.82$ $\left(\mathrm{dd}, 1 \mathrm{H}, J_{5,6 \mathrm{a}} 4.9 \mathrm{~Hz}, J_{6 \mathrm{a}, 6 \mathrm{~b}} 12.1 \mathrm{~Hz}, \mathrm{H}-6 \mathrm{a}\right)$, $3.87\left(\mathrm{t}, 1 \mathrm{H}, J_{4,5} 9.5 \mathrm{~Hz}, \mathrm{H}-4\right), 3.92(\mathrm{dd}, 1 \mathrm{H}$, $\left.J_{5,6 \mathrm{~b}} 3.7 \mathrm{~Hz}, \mathrm{H}-6 \mathrm{~b}\right), 3.95$ (d, $1 \mathrm{H}, J_{2,3} 3.6 \mathrm{~Hz}$, H-2), 4.56 (br. s, $1 \mathrm{H}, \mathrm{H}-1), 4.61,4.74$ (2 d, 2 $\left.\mathrm{H}, J_{\text {gem }} 11.7 \mathrm{~Hz}, \mathrm{PhCH}_{2}\right), 4.64,4.94(2 \mathrm{~d}, 2 \mathrm{H}$, $\left.J_{\text {gem }} 12.2 \mathrm{~Hz}, \mathrm{PhCH}_{2}\right), 7.30-7.42(\mathrm{~m}, 10 \mathrm{H}, 2$ Ph). Anal. Calcd for $\mathrm{C}_{20} \mathrm{H}_{23} \mathrm{~N}_{3} \mathrm{O}_{5}: \mathrm{C}, 62.32 ; \mathrm{H}$, 6.02; N, 10.90. Found: C, 62.46; H, 5.92; N, 10.85 .

Benzyl 2-azido-3-O-benzyl-2-deoxy-6-O-tosyl- $\beta$-D-mannopyranoside (18). $-p$-Toluenesulfonyl chloride $(1.72 \mathrm{~g}, 9.04 \mathrm{mmol})$ was added at $0{ }^{\circ} \mathrm{C}$ to a solution of 17 (2.32 g, 6.02 $\mathrm{mmol})$ in py $(15 \mathrm{~mL})$. The stirred mixture was allowed to warm to $\mathrm{rt}$ for $1.5 \mathrm{~h}$, and stirring was continued for the next $2 \mathrm{~h}$. The reaction was quenched by adding water, the resulting mixture was diluted with $\mathrm{CHCl}_{3}$, washed successively with water, $\mathrm{M} \mathrm{HCl}$, and water, and concentrated. Column chromatography of the residue (9:1 toluene-EtOAc) yielded $\mathbf{1 8}$ (2.86 g, 88\%) as a syrup: $[\alpha]_{\mathrm{D}}-79.6^{\circ}\left(\mathrm{c} \mathrm{2}, \mathrm{CHCl}_{3}\right)$. ${ }^{1} \mathrm{H}$ NMR: $\delta 2.41$ (s, $3 \mathrm{H}, \mathrm{CH}_{3} \mathrm{C}_{6} \mathrm{H}_{4}$ ), 2.47 (br. $\mathrm{s}, 1 \mathrm{H}, \mathrm{OH}), 3.39$ (dd, $\left.1 \mathrm{H}, J_{3,4} 9.1 \mathrm{~Hz}, \mathrm{H}-3\right)$, 3.42 (ddd, $1 \mathrm{H}, \mathrm{H}-5), 3.70$ (t, $1 \mathrm{H}, J_{4,5} 9.8 \mathrm{~Hz}$, $\mathrm{H}-4), 3.94$ (d, $\left.1 \mathrm{H}, J_{2,3} 3.4 \mathrm{~Hz}, \mathrm{H}-2\right), 4.23$ (dd, $\left.1 \mathrm{H}, J_{5,6 \mathrm{a}} 6.6 \mathrm{~Hz}, J_{6 \mathrm{a}, 6 \mathrm{~b}} 10.9 \mathrm{~Hz}, \mathrm{H}-6 \mathrm{a}\right), 4.43$ (dd, $\left.1 \mathrm{H}, J_{5,6 \mathrm{~b}} 1.7 \mathrm{~Hz}, \mathrm{H}-6 \mathrm{~b}\right), 4.48$ (s, 1H, $\mathrm{H}-1), 4.56$ (d,2 H, $\left.J_{\text {gem }} 11.8 \mathrm{~Hz}, \mathrm{PhCH}_{2}\right), 4.73$ $\left(\mathrm{d}, 1 \mathrm{H}, J_{\text {gem }} 11.7 \mathrm{~Hz}, \mathrm{PhCH}_{2}\right), 4.86(\mathrm{~d}, 1 \mathrm{H}$, $\left.J_{\text {gem }} 12.0 \mathrm{~Hz}, \mathrm{PhCH}_{2}\right), 7.30-7.84(\mathrm{~m}, 14 \mathrm{H}, 2$ $\mathrm{Ph}, \mathrm{CH}_{3} \mathrm{C}_{6} \mathrm{H}_{4}$ ). Anal. Calcd for $\mathrm{C}_{27} \mathrm{H}_{29} \mathrm{~N}_{3} \mathrm{O}_{7} \mathrm{~S}$ : C, 60.10; H, 5.42; N, 7.79. Found: C, 59.89; $\mathrm{H}, 5.57 ; \mathrm{N}, 8.03$. 
Benzyl 2-azido-3-O-benzyl-2,6-dideoxy-6iodo- $\beta$-D-mannopyranoside (19). - A solution of $18(2.76 \mathrm{~g}, 5.12 \mathrm{mmol})$ and sodium iodide (3.84 $\mathrm{g}, 25.6 \mathrm{mmol})$ in $\mathrm{CH}_{3} \mathrm{CN}(30 \mathrm{~mL})$ was heated with stirring at $80-85^{\circ} \mathrm{C}$ for $7 \mathrm{~h}$. The solvent was evaporated, and a suspension of the residue in $\mathrm{CHCl}_{3}$ was washed successively with water, $\mathrm{M} \mathrm{Na} \mathrm{S}_{2} \mathrm{O}_{3}$, and water, and then concentrated. The residue was chromatographed (95:5 toluene-EtOAc) to give $\mathbf{1 9}$ $(2.42 \mathrm{~g}, 96 \%)$ as a syrup: $[\alpha]_{\mathrm{D}}-77.3^{\circ}(c)$, $\left.\mathrm{CHCl}_{3}\right) .{ }^{1} \mathrm{H}$ NMR: $\delta 3.22(\mathrm{dt}, 1 \mathrm{H}, \mathrm{H}-5), 2.46$ $\left(\mathrm{d}, 1 \mathrm{H}, J_{4, \mathrm{OH}} 1.5 \mathrm{~Hz}, \mathrm{OH}\right), 3.30\left(\mathrm{t}, 1 \mathrm{H}, J_{5,6 \mathrm{a}}\right.$ $\left.9.1 \mathrm{~Hz}, J_{6 \mathrm{a}, 6 \mathrm{~b}} 10.4 \mathrm{~Hz}, \mathrm{H}-6 \mathrm{a}\right), 3.39$ (dd, $1 \mathrm{H}$, $\left.J_{3,4} 9.0 \mathrm{~Hz}, \mathrm{H}-3\right), 3.64$ (dt, $1 \mathrm{H}, J_{4,5} 8.9 \mathrm{~Hz}$, $\mathrm{H}-4), 3.65$ (dd, $\left.1 \mathrm{H}, J_{5,6 \mathrm{~b}} 1.8 \mathrm{~Hz}, \mathrm{H}-6 \mathrm{~b}\right), 3.97$ $\left(\mathrm{d}, 1 \mathrm{H}, J_{2,3} 3.4 \mathrm{~Hz}, \mathrm{H}-2\right), 4.53,4.75(2 \mathrm{~d}, 2 \mathrm{H}$, $J_{\text {gem }} 11.6 \mathrm{~Hz}, \mathrm{PhCH}_{2}$ ), 4.54 (s, $\left.1 \mathrm{H}, \mathrm{H}-1\right), 4.75$, $5.02\left(2 \mathrm{~d}, 2 \mathrm{H}, J_{\text {gem }} 12.1 \mathrm{~Hz}, \mathrm{PhCH}_{2}\right), 7.33-$ $7.45(\mathrm{~m}, 10 \mathrm{H}, 2 \mathrm{Ph})$. Anal. Calcd for $\mathrm{C}_{20} \mathrm{H}_{22} \mathrm{IN}_{3} \mathrm{O}_{4}$ : C, 48.50; $\mathrm{H}, 4.48 ; \mathrm{N}, 8.48$.

Found: C, 48.23; H, 4.47; N, 8.18.

Benzyl 2-acetamido-3-O-benzyl-2,6-dideoxy- $\beta$-D-mannopyranoside (20). - A solution of $19(2.50 \mathrm{~g}, 5.05 \mathrm{mmol})$ and $N, N$-diisopropylethylamine $(1.75 \mathrm{~mL}, 10.1 \mathrm{mmol})$ in $\mathrm{MeOH}(25 \mathrm{~mL})$ was stirred with $20 \%$ $\mathrm{Pd}(\mathrm{OH})_{2} / \mathrm{C}(1 \mathrm{~g})$ under hydrogen at $32{ }^{\circ} \mathrm{C}$ for $6 \mathrm{~h}$. The catalyst was filtered off through Celite and washed with $\mathrm{MeOH}$, and the combined filtrate and washings were treated with Dowex $1 \times 8\left(\mathrm{HCO}_{3}^{-}\right)$anion-exchange resin, filtered, and concentrated. $\mathrm{Ac}_{2} \mathrm{O}(2.5 \mathrm{~mL})$ was added to a solution of the residue in $\mathrm{MeOH}$ (25 $\mathrm{mL})$, and the mixture was kept overnight at $\mathrm{rt}$. The solvent was evaporated, $\mathrm{Ac}_{2} \mathrm{O}$ was removed by coevaporation with toluene, and the residue was subjected to column chromatography (85:15 toluene-acetone) to give $20(1.63 \mathrm{~g}, 84 \%)$ as a foam: $[\alpha]_{\mathrm{D}}-116^{\circ}(c 1$, $\left.\mathrm{CHCl}_{3}\right) .{ }^{1} \mathrm{H}$ NMR: $\delta 1.49\left(\mathrm{~d}, 3 \mathrm{H}, J_{5,6} 6.3 \mathrm{~Hz}\right.$, $\mathrm{H}-6), 2.08$ (s, $\left.3 \mathrm{H}, \mathrm{CH}_{3} \mathrm{CO}\right), 3.27\left(\mathrm{t}, 1 \mathrm{H}, J_{4,5}\right.$ $9.1 \mathrm{~Hz}, \mathrm{H}-4), 3.32$ (dq, $1 \mathrm{H}, \mathrm{H}-5), 3.35$ (dd, 1 $\left.\mathrm{H}, J_{3,4} 9.1 \mathrm{~Hz}, \mathrm{H}-3\right), 4.39,4.93\left(2 \mathrm{~d}, 2 \mathrm{H}, J_{\text {gem }}\right.$ $10.9 \mathrm{~Hz}, \mathrm{PhCH}_{2}$ ), 4.54 (s, $\left.1 \mathrm{H}, \mathrm{H}-1\right), 4.63,4.86$ $\left(2 \mathrm{~d}, 2 \mathrm{H}, J_{\text {gem }} 12.2 \mathrm{~Hz}, \mathrm{PhCH}_{2}\right), 4.84(\mathrm{dd}, 1$ $\left.\mathrm{H}, J_{2,3} 4.0 \mathrm{~Hz}, \mathrm{H}-2\right), 5.74\left(\mathrm{~d}, 1 \mathrm{H}, J_{\mathrm{NH}, 2} 9.5\right.$ $\mathrm{Hz}, \mathrm{NH}), 7.27-7.39$ (m, $10 \mathrm{H}, 2 \mathrm{Ph})$. Anal. Calcd for $\mathrm{C}_{22} \mathrm{H}_{27} \mathrm{NO}_{5}: \mathrm{C}, 68.55 ; \mathrm{H}, 7.06 ; \mathrm{N}$, 3.63. Found: C, 68.65; H, 7.11; N, 3.52.
Benzyl 2-acetamido-3-O-benzyl-2,6-dideoxy- $\beta$-D-lyxo-hexopyranoside-4-ulose, oxime (22). - A solution of DMSO $(0.97 \mathrm{~mL}, 13.6$ $\mathrm{mmol})$ in $\mathrm{CH}_{2} \mathrm{Cl}_{2}(4 \mathrm{~mL})$ was added at $-60{ }^{\circ} \mathrm{C}$ to a solution of oxalyl chloride $(0.54$ $\mathrm{mL}, 6.19 \mathrm{mmol})$ in $\mathrm{CH}_{2} \mathrm{Cl}_{2}(15 \mathrm{~mL})$, and the mixture was stirred for $0.5 \mathrm{~h}$ while the temperature gradually increased to $-30^{\circ} \mathrm{C}$. After cooling to $-60{ }^{\circ} \mathrm{C}$, a solution of 20 (1.59 g, $4.13 \mathrm{mmol})$ in $\mathrm{CH}_{2} \mathrm{Cl}_{2}(15 \mathrm{~mL})$ was added dropwise, the mixture was stirred at $-60{ }^{\circ} \mathrm{C}$ for $45 \mathrm{~min}$, and then $N, N$-diisopropylethylamine $(5.3 \mathrm{~mL})$ was added. The mixture was allowed to warm to $-20^{\circ} \mathrm{C}$, diluted with $\mathrm{CHCl}_{3}$, washed with $\mathrm{M} \mathrm{HCl}$, water, and concentrated. The residue was passed through a short column with silica gel in $(85: 15)$ toluene-acetone, and the eluate was concentrated to afford 21. Hydroxylamine hydrochloride (565 mg, $8.1 \mathrm{mmol}$ ) was added to a solution of the ketone 21 in a mixture of $\mathrm{CH}_{2} \mathrm{Cl}_{2}(12 \mathrm{~mL})$ and py $(9 \mathrm{~mL})$, and the solution was stirred at rt overnight. The mixture was diluted with $\mathrm{CHCl}_{3}$, and washed with water, and the water phase was extracted twice with $\mathrm{CHCl}_{3}$. The combined organic extract was concentrated, and the residue was chromatographed $3: 2$ toluene-acetone) to give $22(1.59 \mathrm{~g}, 97 \%)$ as a mixture of isomers in a ratio of $\sim 8: 1$. Crystallization from ether-light petroleum gave the major isomer: $\mathrm{mp} 127-129^{\circ} \mathrm{C},[\alpha]_{\mathrm{D}}-35^{\circ}(c$ 1, $\left.\mathrm{CHCl}_{3}\right) .{ }^{1} \mathrm{H}$ NMR: $\delta 1.64\left(\mathrm{~d}, 3 \mathrm{H}, J_{5,6} 7.1\right.$ $\mathrm{Hz}, \mathrm{H}-6), 2.00$ (s, $3 \mathrm{H}, \mathrm{CH}_{3} \mathrm{CO}$ ), 4.28 (d, $1 \mathrm{H}$, $\left.J_{1,2} 4.9 \mathrm{~Hz}, \mathrm{H}-1\right), 4.47$ (ddd, $1 \mathrm{H}, J_{2,3} 4.3 \mathrm{~Hz}$, $\mathrm{H}-2), 4.30,5.01\left(2 \mathrm{~d}, 2 \mathrm{H}, J_{\text {gem }} 12.0 \mathrm{~Hz}\right.$, $\left.\mathrm{PhCH}_{2}\right), 4.51,4.67\left(2 \mathrm{~d}, 2 \mathrm{H}, J_{\text {gem }} 11.9 \mathrm{~Hz}\right.$, $\left.\mathrm{PhCH}_{2}\right), 4.92(\mathrm{~d}, 1 \mathrm{H}, \mathrm{H}-3), 5.29(\mathrm{q}, 1 \mathrm{H}$, $\mathrm{H}-5), 6.45$ (d, $\left.1 \mathrm{H}, J_{\mathrm{NH}, 2} 9.6 \mathrm{~Hz}, \mathrm{NH}\right), 7.25-$ $7.38(\mathrm{~m}, 10 \mathrm{H}, 2 \mathrm{Ph})$. Anal. Calcd for $\mathrm{C}_{22} \mathrm{H}_{26} \mathrm{~N}_{2} \mathrm{O}_{5}$ : C, 66.31; H, 6.58; N, 7.03. Found: C, 66.40; H, 6.54; N, 6.88.

Benzyl 2,4-diacetamido-3-O-benzyl-2,4,6trideoxy- $\beta$-D-talopyranoside (23) and benzyl 2,4-diacetamido-3-O-benzyl-2,4,6-trideoxy- $\beta$ D-mannopyranoside (24). - Sodium borohydride (1.55 g, $40.7 \mathrm{mmol})$ was added portionwise to a solution of $22(1.62 \mathrm{~g}, 4.07$ $\mathrm{mmol})$ and $\mathrm{NiCl}_{2} \cdot 6 \mathrm{H}_{2} \mathrm{O}(1.94 \mathrm{~g}, 8.14 \mathrm{mmol})$ in $\mathrm{MeOH}(50 \mathrm{~mL})$ at $-35^{\circ} \mathrm{C}$ over $0.5 \mathrm{~h}$. The mixture was stirred at the same temperature for $0.5 \mathrm{~h}$ and quenched by adding satd aq 
$\mathrm{NaHCO}_{3}(50 \mathrm{~mL})$. The bulk of the $\mathrm{MeOH}$ was evaporated, and the remaining aqueous solution was extracted with $\mathrm{CH}_{2} \mathrm{Cl}_{2}(3 \times 50$ $\mathrm{mL})$. The combined extract was concentrated, and the residue was acetylated with $\mathrm{Ac}_{2} \mathrm{O}(1.5$ $\mathrm{mL})$ in $\mathrm{MeOH}(20 \mathrm{~mL})$ overnight. The solvent was evaporated, the $\mathrm{Ac}_{2} \mathrm{O}$ was coevaporated with toluene, and the residue was subjected to column chromatography $\left(95: 5 \quad \mathrm{CHCl}_{3}-\right.$ $\mathrm{MeOH})$ to yield a mixture of $\mathbf{2 3}$ and $\mathbf{2 4}$. Individual $23(1.39 \mathrm{~g}, 80 \%)$ and 24 (130 $\mathrm{mg}$, $8 \%$ ) were isolated by preparative HPLC on a Zorbax SIL $(250 \times 21 \mathrm{~mm})$ column (DuPont) in 97:3 EtOAc-MeOH.

Compound 23: $\mathrm{mp} 158-159{ }^{\circ} \mathrm{C}(\mathrm{MeOH}-$ $\left.\mathrm{Et}_{2} \mathrm{O}\right),[\alpha]_{\mathrm{D}}-49.4^{\circ}$ (c $\left.1, \mathrm{CHCl}_{3}\right) .{ }^{1} \mathrm{H} \mathrm{NMR}$ (toluene- $\left.d_{8}, 333 \mathrm{~K}\right): \delta 1.50\left(\mathrm{~d}, 3 \mathrm{H}, J_{5,6} 6.3 \mathrm{~Hz}\right.$, $\mathrm{H}-6), 1.98,2.00$ (2 s, $\left.6 \mathrm{H}, 2 \mathrm{CH}_{3} \mathrm{CO}\right), 3.53$ (poorly resolved q, $1 \mathrm{H}, \mathrm{H}-5$ ), 3.61 (poorly resolved t, $\left.1 \mathrm{H}, J_{2,3} \sim J_{3,4} \sim 2 \mathrm{~Hz}, \mathrm{H}-3\right), 4.60$ (s, $1 \mathrm{H}, \mathrm{H}-1$ ), 4.62 (unresolved, $1 \mathrm{H}, \mathrm{H}-4$ ), 4.69, $4.98\left(2 \mathrm{~d}, 2 \mathrm{H}, J_{\text {gem }} 12.0 \mathrm{~Hz}, \mathrm{PhCH}_{2}\right)$, 4.79 (unresolved, $1 \mathrm{H}, \mathrm{H}-2), 4.81$ (s, $2 \mathrm{H}$ $\mathrm{PhCH}_{2}$ ), 6.18 (unresolved, $\left.1 \mathrm{H}, \mathrm{NH}\right), 6.44$ (unresolved, $1 \mathrm{H}, \mathrm{NH}), 7.33-7.73(\mathrm{~m}, 10 \mathrm{H}, 2$ Ph). Anal. Calcd for $\mathrm{C}_{24} \mathrm{H}_{30} \mathrm{~N}_{2} \mathrm{O}_{5}$ : C, 67.58; H, 7.09; N, 6.57. Found: C, 67.44; H, 7.07; N, 6.56 .

Compound 24 was obtained as a foam: $[\alpha]_{\mathrm{D}}$ $-109.5^{\circ}$ ( c 1, $\left.\mathrm{CHCl}_{3}\right) .{ }^{1} \mathrm{H} \operatorname{NMR}\left(\mathrm{C}_{6} \mathrm{D}_{6}\right): \delta$ $1.37\left(\mathrm{~d}, 3 \mathrm{H}, J_{5,6} 6.2 \mathrm{~Hz}, \mathrm{H}-6\right), 1.68,1.70(2 \mathrm{~s}$, $\left.6 \mathrm{H}, 2 \mathrm{CH}_{3} \mathrm{CO}\right), 3.02$ (dq, $\left.1 \mathrm{H}, \mathrm{H}-5\right), 3.15$ (dd, $\left.1 \mathrm{H}, J_{3,4} 10.3 \mathrm{~Hz}, \mathrm{H}-3\right), 3.94$ (q, $1 \mathrm{H}, J_{4,5} 9.8$ Hz, H-4), 4.35 (s, 1 H, H-1), 4.43, 4.84 (2 d, 2 $\left.\mathrm{H}, J_{\text {gem }} 12.2 \mathrm{~Hz}, \mathrm{PhCH}_{2}\right), 4.57,4.94(2 \mathrm{~d}, 2 \mathrm{H}$, $\left.J_{\text {gem }} 12.2 \mathrm{~Hz}, \mathrm{PhCH}_{2}\right), 4.86\left(\mathrm{~d}, 1 \mathrm{H}, J_{\mathrm{NH}, 4} 8.9\right.$ $\mathrm{Hz}, \mathrm{NH}-4), 5.09$ (dd, $1 \mathrm{H}, J_{2,3} 4.2 \mathrm{~Hz}, \mathrm{H}-2$ ), $6.29\left(\mathrm{~d}, 1 \mathrm{H}, J_{\mathrm{NH}, 2} 9.7 \mathrm{~Hz}, \mathrm{NH}-2\right), 7.08-7.39$ $(\mathrm{m}, 10 \mathrm{H}, 2 \mathrm{Ph})$. Anal. Calcd for $\mathrm{C}_{24} \mathrm{H}_{30} \mathrm{~N}_{2} \mathrm{O}_{5}$ : C, 67.58; H, 7.09; N, 6.57. Found: C, 66.86; $\mathrm{H}, 6.96 ; \mathrm{N}, 6.69$.

2,4 - Diacetamido - 2,4,6 - trideoxy - D - talose (25). - A solution of $23(1.24 \mathrm{~g}, 2.91 \mathrm{mmol})$ in $\mathrm{MeOH}(20 \mathrm{~mL})$ and water $(10 \mathrm{~mL})$ was stirred with $20 \% \mathrm{Pd}(\mathrm{OH})_{2} / \mathrm{C}(500 \mathrm{mg})$ under hydrogen for $6 \mathrm{~h}$ at $\mathrm{rt}$. The catalyst was filtered through Celite, and washed with $\mathrm{MeOH}$, (Caution: Extreme fire hazard), the combined filtrate and washings were concentrated, and the residue was subjected to column chromatography $\left(85: 15 \mathrm{CHCl}_{3}-\mathrm{MeOH}\right)$ to give 25
(630 mg, 88\%) as an amorphous solid: $[\alpha]_{\mathrm{D}}$ $+23.6^{\circ} \rightarrow+15.3^{\circ}$ (c 1, water). For ${ }^{1} \mathrm{H}$ and ${ }^{13} \mathrm{C}$ NMR data see Table 1. Anal. Calcd for $\mathrm{C}_{10} \mathrm{H}_{18} \mathrm{~N}_{2} \mathrm{O}_{5}$ : C, 48.77; $\mathrm{H}, 7.37 ; \mathrm{N}, 11.38$. Found: C, 48.98; H, 7.57; N, 11.42.

Benzyl 3-O-benzoyl- $\beta$-D-fucopyranoside (27). - A mixture of 26 (2.22 g, $8.74 \mathrm{mmol})$ and $\mathrm{Bu}_{2} \mathrm{SnO}(2.29 \mathrm{~g}, 9.18 \mathrm{mmol})$ in benzene $(40 \mathrm{~mL})$ was boiled with stirring and azeotropic removal of water for $5 \mathrm{~h}$, then 15 $\mathrm{mL}$ benzene was distilled off from the mixture. The remaining solution was cooled to $0{ }^{\circ} \mathrm{C}$ and benzoyl chloride $(1.12 \mathrm{~mL}, 9.61$ $\mathrm{mmol})$ was added. After stirring at $0-5^{\circ} \mathrm{C}$ for $2 \mathrm{~h}, \mathrm{MeOH}(0.5 \mathrm{~mL})$ and py $(0.5 \mathrm{~mL})$ were added to destroy the excess benzoyl chloride. After being stirred for $0.5 \mathrm{~h}$ at $\mathrm{rt}$, the mixture was concentrated, and the residue was subjected to column chromatography (9:1 toluene-EtOAc) to give $27(1.90 \mathrm{~g}, 61 \%): \mathrm{mp}$ 97-98 ${ }^{\circ} \mathrm{C}$ (EtOAc-light petroleum); $[\alpha]_{\mathrm{D}}+$ $\left.12.5^{\circ}(c) 1, \mathrm{CHCl}_{3}\right) .{ }^{1} \mathrm{H}$ NMR: $\delta 1.38(\mathrm{~d}, 3 \mathrm{H}$, $\left.J_{5,6} 6.4 \mathrm{~Hz}, \mathrm{H}-6\right), 2.11,2.34$ (2 br. s, $2 \mathrm{H}, 2$ $\mathrm{OH}), 3.76$ (q, $1 \mathrm{H}, \mathrm{H}-5), 3.96$ (d, $1 \mathrm{H}, \mathrm{H}-4)$, $4.03\left(\mathrm{dd}, 1 \mathrm{H}, J_{2,3} 10.1 \mathrm{~Hz}, \mathrm{H}-2\right), 4.47$ (d, $1 \mathrm{H}$, $\left.J_{1,2} 7.7 \mathrm{~Hz}, \mathrm{H}-1\right), 4.65,4.99\left(2 \mathrm{~d}, 2 \mathrm{H}, J_{\text {gem }}\right.$ $\left.11.7 \mathrm{~Hz}, \mathrm{PhCH}_{2}\right), 5.07\left(\mathrm{dd}, 1 \mathrm{H}, J_{3,4} 3.0 \mathrm{~Hz}\right.$, $\mathrm{H}-3), 7.32-8.11(\mathrm{~m}, 10 \mathrm{H}, 2 \mathrm{Ph})$. Anal. Calcd for $\mathrm{C}_{20} \mathrm{H}_{22} \mathrm{O}_{6}$ : C, 67.02; H, 6.19. Found: C, 66.92; H, 6.29.

Benzyl 2,4-diazido-3-O-benzoyl-2,4,6-trideoxy- $\beta$-D-mannopyranoside (29). - $\mathrm{Tf}_{2} \mathrm{O} \quad(3.10$ $\mathrm{mL}, 18.5 \mathrm{mmol}$ ) was added dropwise at $0{ }^{\circ} \mathrm{C}$ to a solution of $27(2.20 \mathrm{~g}, 6.14 \mathrm{mmol})$ and py (2.98 mL, $36.8 \mathrm{mmol})$ in $\mathrm{CH}_{2} \mathrm{Cl}_{2}(40 \mathrm{~mL})$. The mixture was stirred at $0{ }^{\circ} \mathrm{C}$ for $1 \mathrm{~h}$, diluted with $\mathrm{CHCl}_{3}$, washed successively with water, $\mathrm{M} \mathrm{HCl}$, and water, and concentrated. The crude ditriflate $\mathbf{2 8}$ obtained was dissolved in toluene $(40 \mathrm{~mL})$ and tetrabutylammoniun azide (10.45 g, $36.8 \mathrm{mmol}$ ) was added. The mixture was stirred for $1 \mathrm{~h}$ at $65-70{ }^{\circ} \mathrm{C}$ and then for $1.5 \mathrm{~h}$ at $100-105^{\circ} \mathrm{C}$, cooled, diluted with toluene, washed twice with water, and concentrated. Column chromatography of the residue (7:3 toluene-light petroleum) gave 29 $(2.12 \mathrm{~g}, 85 \%)$ as a syrup, $[\alpha]_{\mathrm{D}}-46.1^{\circ}$ (c 1, $\left.\mathrm{CHCl}_{3}\right) .{ }^{1} \mathrm{H}$ NMR: $\delta 1.59\left(\mathrm{~d}, 3 \mathrm{H}, J_{5,6} 6.1 \mathrm{~Hz}\right.$, H-6), 3.40 (dq, $1 \mathrm{H}, \mathrm{H}-5), 3.77$ (t, $1 \mathrm{H}, J_{4,5} 9.7$ $\mathrm{Hz}, \mathrm{H}-4), 4.36$ (d, $\left.1 \mathrm{H}, J_{2,3} 3.6 \mathrm{~Hz}, \mathrm{H}-2\right), 4.77$, 5.09 (2 d, $\left.2 \mathrm{H}, J_{\text {gem }} 12.1 \mathrm{~Hz}, \mathrm{PhCH}_{2}\right), 4.77$ (s, 
$1 \mathrm{H}, \mathrm{H}-1), 5.14$ (dd, $1 \mathrm{H}, J_{3,4} 10.1 \mathrm{~Hz}, \mathrm{H}-3$ ), 7.40-8.23 (m, $10 \mathrm{H}, 2 \mathrm{Ph})$. Anal. Calcd for $\mathrm{C}_{20} \mathrm{H}_{20} \mathrm{~N}_{6} \mathrm{O}_{4}$ : C, 58.81; H, 4.94; N, 20.58. Found: C, 59.18; H, 5.05; N, 20.61.

Benzyl 2,4-diacetamido-2,4,6-trideoxy- $\beta$-Dmannopyranoside (31). - A solution of 29 (2.12 $\mathrm{g}, 5.20 \mathrm{mmol})$ in $\mathrm{MeOH}(20 \mathrm{~mL})$ was treated with $2 \mathrm{M}$ sodium methoxide in $\mathrm{MeOH}$ $(1 \mathrm{~mL})$ for $1 \mathrm{~h}$ at $\mathrm{rt}$. The solution was neutralised by adding Amberlite IR-120 $\left(\mathrm{H}^{+}\right.$ form) ion-exchange resin, and filtered, and the filtrate was concentrated. A solution of crude 30 in $\mathrm{MeOH}(30 \mathrm{~mL})$ was stirred with $20 \%$ $\mathrm{Pd}(\mathrm{OH})_{2} / \mathrm{C}(400 \mathrm{mg})$ at $30^{\circ} \mathrm{C}$ under hydrogen for $1.5 \mathrm{~h}$. The catalyst was filtered off through Celite, washed with $\mathrm{MeOH}$, and the combined filtrate and washings were concentrated to a volume of $\sim 20 \mathrm{~mL}$, then $\mathrm{Ac}_{2} \mathrm{O}(2 \mathrm{~mL})$ was added. After being kept for $1 \mathrm{~h}$ at $\mathrm{rt}$, the mixture was evaporated to dryness, and the residue was subjected to column chromatography $\left(97: 3 \mathrm{CHCl}_{3}-\mathrm{MeOH}\right)$ to yield 31 (1.51 g, $86 \%)$ as a foam: $[\alpha]_{\mathrm{D}}-25.2^{\circ}\left(c 1, \mathrm{CHCl}_{3}\right) .{ }^{1} \mathrm{H}$ $\mathrm{NMR}\left(\mathrm{C}_{6} \mathrm{D}_{6}+\mathrm{CD}_{3} \mathrm{OD}\right): \delta 1.40\left(\mathrm{~d}, 3 \mathrm{H}, J_{5,6}\right.$ $6.2 \mathrm{~Hz}, \mathrm{H}-6), 1.86,1.96\left(2 \mathrm{~s}, 6 \mathrm{H}, 2 \mathrm{CH}_{3} \mathrm{CO}\right)$, $3.32(\mathrm{dq}, 1 \mathrm{H}, \mathrm{H}-5), 3.83\left(\mathrm{dd}, 1 \mathrm{H}, J_{3,4} 10.5\right.$ $\mathrm{Hz}, \mathrm{H}-3), 3.95$ (t, $\left.1 \mathrm{H}, J_{4,5} 10.1 \mathrm{~Hz}, \mathrm{H}-4\right), 4.50$, $4.80\left(2 \mathrm{~d}, 2 \mathrm{H}, J_{\text {gem }} 12.0 \mathrm{~Hz}, \mathrm{PhCH}_{2}\right), 4.54(\mathrm{~s}$, $1 \mathrm{H}, \mathrm{H}-1), 4.73\left(\mathrm{~d}, 1 \mathrm{H}, J_{2,3} 2.5 \mathrm{~Hz}, \mathrm{H}-2\right)$, 7.07-7.43 (m, 5 H, Ph). Anal. Calcd for $\mathrm{C}_{17} \mathrm{H}_{24} \mathrm{~N}_{2} \mathrm{O}_{5}$ : C, 60.70; H, 7.19; N, 8.33. Found: C, 60.79; H, 7.24; N, 8.36.

2,4-Diacetamido-2,4,6-trideoxy-D-mannopyranose (32). - A mixture of 31 (1.35 g, 4.02 $\mathrm{mmol})$ and $20 \% \mathrm{Pd}(\mathrm{OH})_{2} / \mathrm{C} \quad(400 \mathrm{mg})$ in $\mathrm{MeOH}(25 \mathrm{~mL})$ was stirred at $32{ }^{\circ} \mathrm{C}$ in hydrogen atmosphere for $2 \mathrm{~h}$. The catalyst was filtered through Celite, washed with $\mathrm{MeOH}$, (Caution: Extreme fire hazard), and the combined filtrate and washings were concentrated. The residue was chromatographed $(85: 15$ $\left.\mathrm{CHCl}_{3}-\mathrm{MeOH}\right)$ to give $32(840 \mathrm{mg}, 85 \%)$ as an amorphous solid: $[\alpha]_{\mathrm{D}}+38.1^{\circ}$ (c 1, water). ${ }^{1} \mathrm{H}$ NMR $\left(\mathrm{D}_{2} \mathrm{O}\right): 32 \alpha, \delta 1.19\left(\mathrm{~d}, 3 \mathrm{H}, J_{5,6} 6.3\right.$ $\mathrm{Hz}, \mathrm{H}-6), 2.04,2.08$ (2 s, $\left.6 \mathrm{H}, 2 \mathrm{CH}_{3} \mathrm{CO}\right), 3.78$ (t, $\left.1 \mathrm{H}, J_{4,5} 10.2 \mathrm{~Hz}, \mathrm{H}-4\right), 3.97$ (dq, $1 \mathrm{H}, \mathrm{H}-5$ ), $4.07\left(\mathrm{dd}, 1 \mathrm{H}, J_{3,4} 10.8 \mathrm{~Hz}, \mathrm{H}-3\right), 4.30(\mathrm{dd}, 1$ $\left.\mathrm{H}, J_{2,3} 4.6 \mathrm{~Hz}, \mathrm{H}-2\right), 5.11\left(\mathrm{~d}, 1 \mathrm{H}, J_{1,2} 1.3 \mathrm{~Hz}\right.$, $\mathrm{H}-1) .32 \beta, \delta 1.23\left(\mathrm{~d}, 3 \mathrm{H}, J_{5,6} 6.2 \mathrm{~Hz}, \mathrm{H}-6\right)$, 2.03, $2.12\left(2 \mathrm{~s}, 6 \mathrm{H}, 2 \mathrm{CH}_{3} \mathrm{CO}\right), 3.51(\mathrm{dq}, 1 \mathrm{H}$, H-5), 3.67 (t, $\left.1 \mathrm{H}, J_{4,5} 10.0 \mathrm{~Hz}, \mathrm{H}-4\right), 3.84$ (dd, $\left.1 \mathrm{H}, J_{3,4} 10.8 \mathrm{~Hz}, \mathrm{H}-3\right), 4.47$ (dd, $1 \mathrm{H}, J_{2,3} 4.3$ $\mathrm{Hz}, \mathrm{H}-2), 4.96$ (d, $\left.1 \mathrm{H}, J_{1,2} 1.3 \mathrm{~Hz}, \mathrm{H}-1\right)$. The ratio $32 \alpha: 32 \beta \approx 55: 45$. Anal. Calcd for $\mathrm{C}_{10} \mathrm{H}_{18} \mathrm{~N}_{2} \mathrm{O}_{5} \cdot 0.5 \mathrm{H}_{2} \mathrm{O}: \mathrm{C}, 47.05 ; \mathrm{H}, 7.50 ; \mathrm{N}$, 10.97. Found: C, 47.21; H, 7.74; N, 11.12.

Benzyl 2,3-O-isopropylidene- $\beta$-L-rhamnopyranoside (33). $-p$-Toluenesulfonic acid monohydrate $(190 \mathrm{mg}, 1 \mathrm{mmol})$ was added to a solution of $5(6.20 \mathrm{~g}, 24.4 \mathrm{mmol})$ and 2,2dimethoxypropane $(18.5 \mathrm{~mL}, 150 \mathrm{mmol})$ in acetone $(50 \mathrm{~mL})$, and the mixture was kept for $1 \mathrm{~h}$ at rt. $\mathrm{A}$ few drops of $\mathrm{Et}_{3} \mathrm{~N}$ were added, the solvent was evaporated, and a solution of the residue in $\mathrm{CHCl}_{3}$ was washed twice with water and concentrated. The residue was crystallized from EtOAc-light petroleum to give $5.77 \mathrm{~g}$ of 33. An additional portion of the product (1.17 g) was obtained by column chromatography (4:1 toluene-EtOAc) of the mother liquor. Total yield of 33 was $6.49 \mathrm{~g}(97 \%)$, mp $97-$ $\left.98^{\circ} \mathrm{C},[\alpha]_{\mathrm{D}}+142.6^{\circ}(c) 1, \mathrm{CHCl}_{3}\right) .{ }^{1} \mathrm{H} \mathrm{NMR}$ : $\delta 1.38\left(\mathrm{~d}, 3 \mathrm{H}, J_{5,6} 6.1 \mathrm{~Hz}, \mathrm{H}-6\right), 1.40,1.58$ (2 $\mathrm{s}, 6 \mathrm{H}$, isopropylidene), $2.61\left(\mathrm{~d}, 1 \mathrm{H}, J_{\mathrm{OH}, 4} 3.1\right.$ $\mathrm{Hz}, \mathrm{OH}$ ), 3.27 (dq, $1 \mathrm{H}, \mathrm{H}-5), 3.56$ (ddd, $1 \mathrm{H}$, $\left.J_{4,5} 9.8 \mathrm{~Hz}, \mathrm{H}-4\right), 3.99$ (t, $1 \mathrm{H}, J_{3,4} 6.4 \mathrm{~Hz}$, H-3), 4.20 (dd, $\left.1 \mathrm{H}, J_{2,3} 5.6 \mathrm{~Hz}, \mathrm{H}-2\right), 4.71$ (d, $\left.1 \mathrm{H}, J_{1,2} 1.3 \mathrm{~Hz}, \mathrm{H}-1\right), 4.75,4.97(2 \mathrm{~d}, 2 \mathrm{H}$, $\left.J_{\text {gem }} 12.5 \mathrm{~Hz}, \mathrm{PhCH}_{2}\right), 7.29-7.40(\mathrm{~m}, 5 \mathrm{H}, \mathrm{Ph})$. Anal. Calcd for $\mathrm{C}_{16} \mathrm{H}_{22} \mathrm{O}_{5}: \mathrm{C}, 65.29 ; \mathrm{H}, 7.53$. Found: C, 65.32; H, 7.50.

Benzyl 6-deoxy-2,3-O-isopropylidene- $\beta$-Ltalopyranoside (35). - A solution of DMSO (4.60 mL, $64.7 \mathrm{mmol})$ in $\mathrm{CH}_{2} \mathrm{Cl}_{2}(10 \mathrm{~mL})$ was added at $-60{ }^{\circ} \mathrm{C}$ to a solution of oxalyl chloride $(2.57 \mathrm{~mL}, 29.4 \mathrm{mmol})$ in $\mathrm{CH}_{2} \mathrm{Cl}_{2}(40$ $\mathrm{mL}$ ) and the mixture was stirred for $20 \mathrm{~min}$ while the temperature gradually increased to $-40{ }^{\circ} \mathrm{C}$. After cooling to $-60{ }^{\circ} \mathrm{C}$, a solution of $33(5.77 \mathrm{~g}, 19.6 \mathrm{mmol})$ in $\mathrm{CH}_{2} \mathrm{Cl}_{2}(50 \mathrm{~mL})$ was added dropwise, the mixture was stirred at $-60{ }^{\circ} \mathrm{C}$ for $45 \mathrm{~min}$, then $N, N$-diisopropylethylamine $(17.4 \mathrm{~mL})$ was added. The mixture was allowed to warm to $-20^{\circ} \mathrm{C}$, diluted with $\mathrm{CHCl}_{3}$, washed with $\mathrm{M} \mathrm{HCl}$, water, and concentrated to yield ketone 34. $\mathrm{NaBH}_{4}(760 \mathrm{mg}$, $20 \mathrm{mmol}$ ) was added at $0{ }^{\circ} \mathrm{C}$ to a solution of crude 34 in $80 \%$ aq EtOH $(60 \mathrm{~mL})$ and the mixture was stirred for $20 \mathrm{~min}$. The reduction was quenched by adding acetone, the solvent was evaporated, and a solution of the residue in $\mathrm{CHCl}_{3}$ was washed with $\mathrm{M} \mathrm{HCl}$, water, and 
concentrated. Column chromatography of the residue (85:15 toluene-EtOAc) afforded $\mathbf{3 5}$ (5.44 g, 94\%), mp $69-70{ }^{\circ} \mathrm{C}$ (ether-hexane), $[\alpha]_{\mathrm{D}}+108.6^{\circ}\left(c 1, \mathrm{CHCl}_{3}\right) .{ }^{1} \mathrm{H} \mathrm{NMR}: \delta 1.40$ (d, $\left.3 \mathrm{H}, J_{5,6} 6.4 \mathrm{~Hz}, \mathrm{H}-6\right), 1.42,1.63(2 \mathrm{~s}, 6 \mathrm{H}$, isopropylidene), $2.81\left(\mathrm{~d}, 1 \mathrm{H}, J_{\mathrm{OH}, 4} 9.8 \mathrm{~Hz}\right.$, $\mathrm{OH}), 3.50$ (q, $1 \mathrm{H}, \mathrm{H}-5), 3.60$ (dd, $1 \mathrm{H}, \mathrm{H}-4)$, $4.16\left(\mathrm{dd}, 1 \mathrm{H}, J_{2,3} 6.3 \mathrm{~Hz}, \mathrm{H}-2\right), 4.21(\mathrm{t}, 1 \mathrm{H}$, $\left.J_{3,4} 5.6 \mathrm{~Hz}, \mathrm{H}-3\right), 4.72\left(\mathrm{~d}, 1 \mathrm{H}, J_{1,2} 2.4 \mathrm{~Hz}\right.$, $\mathrm{H}-1), 4.77,4.97\left(2 \mathrm{~d}, 2 \mathrm{H}, J_{\text {gem }} 12.3 \mathrm{~Hz}\right.$, $\mathrm{PhCH}_{2}$ ), 7.30-7.43 (m, $\left.5 \mathrm{H}, \mathrm{Ph}\right)$. Anal. Calcd for $\mathrm{C}_{16} \mathrm{H}_{22} \mathrm{O}_{5}$ : C, 65.29; $\mathrm{H}, 7.53$. Found: C, 65.35; H, 7.47.

Benzyl 6-deoxy- $\beta$-L-talopyranoside (36).A solution of $35(925 \mathrm{mg}, 3.15 \mathrm{mmol})$ in $80 \%$ aq $\mathrm{AcOH}(10 \mathrm{~mL})$ was heated at $40{ }^{\circ} \mathrm{C}$ for 1.5 $\mathrm{h}$. The solvent was coevaporated several times with toluene, and the residue was subjected to column chromatography $(4: 1$ toluene-acetone) to give $36(795 \mathrm{mg}, 99 \%): \operatorname{mp~} 86-88^{\circ} \mathrm{C}$ (EtOAc-light petroleum), $[\alpha]_{\mathrm{D}}+89.4^{\circ}$ (c 1, $\left.\mathrm{CHCl}_{3}\right) .{ }^{1} \mathrm{H} \mathrm{NMR}: \delta 1.40\left(\mathrm{~d}, 3 \mathrm{H}, J_{5,6} 6.5 \mathrm{~Hz}\right.$, H-6), 3.45 (q, $1 \mathrm{H}, \mathrm{H}-5), 3.48$ (t, $1 \mathrm{H}, J_{3,4} 3.4$ $\mathrm{Hz}, \mathrm{H}-3), 3.53$ (d, $1 \mathrm{H}, \mathrm{H}-4), 3.95$ (d, $1 \mathrm{H}, J_{2,3}$ $3.2 \mathrm{~Hz}, \mathrm{H}-2), 4.38$ (s, $1 \mathrm{H}, \mathrm{H}-1), 4.68,4.96$ (2 d, $\left.2 \mathrm{H}, J_{\text {gem }} 11.9 \mathrm{~Hz}, \mathrm{PhCH}_{2}\right), 7.30-7.38(\mathrm{~m}, 5$ $\mathrm{H}, \mathrm{Ph}$ ). Anal. Calcd for $\mathrm{C}_{13} \mathrm{H}_{18} \mathrm{O}_{5}$ : C, 61.40; H, 7.14. Found: C, 61.34; H, 7.04.

Benzyl 3-O-benzoyl-6-deoxy- $\beta$-L-talopyranoside (37). - A mixture of $\mathbf{3 6}(302 \mathrm{mg}, 1.19$ $\mathrm{mmol})$ and $\mathrm{Bu}_{2} \mathrm{SnO}(311 \mathrm{mg}, 1.25 \mathrm{mmol})$ in benzene $(20 \mathrm{~mL})$ was boiled with stirring and azeotropic removal of water for $2.5 \mathrm{~h}$, then 10 $\mathrm{mL}$ benzene was distilled from the mixture. The remaining solution was cooled to $0{ }^{\circ} \mathrm{C}$, and benzoyl chloride $(152 \mu \mathrm{l}, 1.31 \mathrm{mmol})$ was added. After stirring at $0-5{ }^{\circ} \mathrm{C}$ for $45 \mathrm{~min}$, $\mathrm{MeOH}(0.1 \mathrm{~mL})$ and py $(0.1 \mathrm{~mL})$ were added to destroy the excess of benzoyl chloride. After being stirred for $0.5 \mathrm{~h}$ at $\mathrm{rt}$, the mixture was concentrated, and the residue was subjected to column chromatography (85:15 toluene-EtOAc) to give 37 (334 mg, 78\%): mp $100-102{ }^{\circ} \mathrm{C}$ (ether-light petroleum); $[\alpha]_{\mathrm{D}}+$ $27.1^{\circ}\left(c 1, \mathrm{CHCl}_{3}\right) .{ }^{1} \mathrm{H}$ NMR: $\delta 1.43(\mathrm{~d}, 3 \mathrm{H}$, $\left.J_{5,6} 6.4 \mathrm{~Hz}, \mathrm{H}-6\right), 3.60$ (q, $\left.1 \mathrm{H}, \mathrm{H}-5\right), 3.78$ (d, $1 \mathrm{H}, \mathrm{H}-4), 4.19$ (d, $\left.1 \mathrm{H}, J_{2,3} 3.1 \mathrm{~Hz}, \mathrm{H}-2\right), 4.55$ (s, 1H, H-1), 4.73, $4.99\left(2 \mathrm{~d}, 2 \mathrm{H}, J_{\text {gem }} 11.9 \mathrm{~Hz}\right.$, $\mathrm{PhCH}_{2}$ ), 4.94 (t, $\left.1 \mathrm{H}, J_{3,4} 3.2 \mathrm{~Hz}, \mathrm{H}-3\right), 7.34-$ $8.15(\mathrm{~m}, 10 \mathrm{H}, 2 \mathrm{Ph})$. Anal. Calcd for $\mathrm{C}_{20} \mathrm{H}_{22} \mathrm{O}_{6}$ : C, 67.02; H, 6.19. Found: C, 67.19; $\mathrm{H}, 6.06$.
Benzyl 4-azido-4,6-dideoxy-2,3-O-isopropylidene- $\beta$-L-mannopyranoside (41). - $\mathrm{Tf}_{2} \mathrm{O}(4.87$ $\mathrm{mL}, 29 \mathrm{mmol}$ ) was added dropwise at $0{ }^{\circ} \mathrm{C}$ to a solution of $35(4.27 \mathrm{~g}, 14.5 \mathrm{mmol})$ and py (11.7 mL, $145 \mathrm{mmol})$ in $\mathrm{CH}_{2} \mathrm{Cl}_{2}(40 \mathrm{~mL})$, and the mixture was stirred for $3 \mathrm{~h}$ at the same temperature. After dilution with $\mathrm{CHCl}_{3}$, the solution was washed successively with water, $\mathrm{M} \mathrm{HCl}$, and water, and concentrated to yield crude triflate 40. Sodium azide (4.71g, 72.5 $\mathrm{mmol})$ and dibenzo-18-crown-6 (130 mg, 0.36 mmol) were added to a solution of $\mathbf{4 0}$ in DMF $(40 \mathrm{~mL})$ and the resulting mixture was stirred overnight at rt. Most of the DMF was evaporated, and a suspension of the residue in EtOAc was washed twice with water, then with satd aq $\mathrm{NaCl}$ solution. The organic solution was dried with $\mathrm{MgSO}_{4}$, and concentrated, and the residue was chromatographed (95:5 toluene-EtOAc) to give 41 (3.44 g, 74\%): mp $95-96{ }^{\circ} \mathrm{C}$ (light petroleum); $[\alpha]_{\mathrm{D}}+137.2^{\circ}(\mathrm{c}$ 1, $\left.\mathrm{CHCl}_{3}\right) .{ }^{1} \mathrm{H}$ NMR: $\delta 1.38\left(\mathrm{~d}, 3 \mathrm{H}, J_{5,6} 6.0\right.$ $\mathrm{Hz}, \mathrm{H}-6), 1.40,1.62$ (2 s, $6 \mathrm{H}$, isopropylidene), 3.17 (dq, $1 \mathrm{H}, \mathrm{H}-5), 3.34$ (dd, $1 \mathrm{H}, J_{4,5} 10.3$ Hz, H-4), 4.07 (dd, 1 H, J 7.6 Hz, H-3), 4.17 $\left(\mathrm{dd}, 1 \mathrm{H}, J_{2,3} 5.5 \mathrm{~Hz}, \mathrm{H}-2\right), 4.65\left(\mathrm{~d}, 1 \mathrm{H}, J_{1,2}\right.$ $2.1 \mathrm{~Hz}, \mathrm{H}-1), 4.75,4.97\left(2 \mathrm{~d}, 2 \mathrm{H}, J_{\text {gem }} 12.5\right.$ $\mathrm{Hz}, \mathrm{PhCH}_{2}$ ), 7.28-7.42 (m, $\left.5 \mathrm{H}, \mathrm{Ph}\right)$. Anal. Calcd for $\mathrm{C}_{16} \mathrm{H}_{21} \mathrm{~N}_{3} \mathrm{O}_{4}: \mathrm{C}, 60.17 ; \mathrm{H}, 6.63 ; \mathrm{N}$, 13.16. Found: C, 59.92; H, 6.60; N, 13.30.

Benzyl 4-azido-4,6-dideoxy- $\beta$-L-mannopyranoside (42). - A solution of $\mathbf{4 1}$ (3.37 g, 10.56 $\mathrm{mmol})$ in $80 \%$ aq $\mathrm{AcOH}(30 \mathrm{~mL})$ was heated at $40{ }^{\circ} \mathrm{C}$ for $5 \mathrm{~h}$. The solvent was evaporated and coevaporated several times with toluene. Column chromatography of the residue $(7: 3$ toluene-EtOAc) gave $42(2.79 \mathrm{~g}, 95 \%)$ : $\mathrm{mp}$ $89-91{ }^{\circ} \mathrm{C} \quad\left(\mathrm{Et}_{2} \mathrm{O}\right.$-light petroleum $) ;[\alpha]_{\mathrm{D}}+$ $85.3^{\circ}\left(c 1, \mathrm{CHCl}_{3}\right) .{ }^{1} \mathrm{H} \mathrm{NMR}: \delta 1.41(\mathrm{~d}, 3 \mathrm{H}$, $J_{5,6} 6.1 \mathrm{~Hz}, \mathrm{H}-6$ ), 2.71 (br s, $1 \mathrm{H}, \mathrm{OH}-2$ ), 2.80 $\left(\mathrm{d}, 1 \mathrm{H}, J_{3, \mathrm{OH}} 8.4 \mathrm{~Hz}, \mathrm{OH}-3\right), 3.15(\mathrm{dq}, 1 \mathrm{H}$, H-5), 3.29 (t, $\left.1 \mathrm{H}, J_{4,5} 9.8 \mathrm{~Hz}, \mathrm{H}-4\right), 3.54$ (m, $\left.1 \mathrm{H}, J_{3,4} 9.6 \mathrm{~Hz}, \mathrm{H}-3\right), 3.97$ (d, $1 \mathrm{H}, J_{2,3} 3.0$ Hz, H-2), 4.44 (s, 1 H, H-1), 4.64, 4.92 (2 d, 2 $\left.\mathrm{H}, J_{\text {gem }} 11.8 \mathrm{~Hz}, \mathrm{PhCH}_{2}\right), 7.33-7.39(\mathrm{~m}, 5 \mathrm{H}$, $\mathrm{Ph})$. Anal. Calcd for $\mathrm{C}_{13} \mathrm{H}_{17} \mathrm{~N}_{3} \mathrm{O}_{4}: \mathrm{C}, 55.90 ; \mathrm{H}$, 6.14; N, 15.05. Found: C, 56.02; H, 6.38; N, 15.24 .

Benzyl 4-azido-3-O-benzoyl-4,6-dideoxy- $\beta$ L-mannopyranoside (43). - Diol 42 (3.25 g, $11.65 \mathrm{mmol})$ was subjected to $\mathrm{Bu}_{2} \mathrm{SnO}$-medi- 
ated benzoylation as described for 37. After column chromatography of the reaction mixture (95:5 toluene-EtOAc), the monobenzoate $43(3.98 \mathrm{~g}, 89 \%)$ was obtained as a syrup: $[\alpha]_{\mathrm{D}}$ $+126^{\circ}\left(c 1, \mathrm{CHCl}_{3}\right) .{ }^{1} \mathrm{H} \mathrm{NMR}: \delta 1.50(\mathrm{~d}, 3 \mathrm{H}$, $\left.J_{5,6} 6.1 \mathrm{~Hz}, \mathrm{H}-6\right), 2.52$ (broad s, $1 \mathrm{H}, \mathrm{OH}$ ), $3.34(\mathrm{dq}, 1 \mathrm{H}, \mathrm{H}-5), 3.82\left(\mathrm{t}, 1 \mathrm{H}, J_{4.5} 9.7 \mathrm{~Hz}\right.$, H-4), 4.31 (broad s, $1 \mathrm{H}, \mathrm{H}-2$ ), 4.59 (s, 1 $\mathrm{H}, \mathrm{H}-1), 4.69,4.94\left(2 \mathrm{~d}, 2 \mathrm{H}, J_{\text {gem }} 11.9\right.$ $\mathrm{Hz}, \mathrm{PhCH}_{2}$ ), 5.00 (dd, $1 \mathrm{H}, J_{3,4} 10.2 \mathrm{~Hz}$, $\left.J_{2,3} 2.6 \mathrm{~Hz}, \mathrm{H}-3\right), 7.32-8.16(\mathrm{~m}, 10 \mathrm{H}, 2 \mathrm{Ph})$. Anal. Calcd for $\mathrm{C}_{20} \mathrm{H}_{21} \mathrm{~N}_{3} \mathrm{O}_{5}: \mathrm{C}, 62.65 ; \mathrm{H}$, 5.52; N, 10.96. Found: C, 62.74; H, 5.51; N, 11.00 .

Benzyl 2,4-diazido-3-O-benzoyl-2,4,6-trideoxy- $\beta$-L-glucopyranoside (39). - $\mathrm{Tf}_{2} \mathrm{O} \quad(3.36$ $\mathrm{mL}, 20 \mathrm{mmol})$ was added at $0{ }^{\circ} \mathrm{C}$ to a solution of $43(3.84 \mathrm{~g}, 10.03 \mathrm{mmol})$ and py $(4.04 \mathrm{~mL}$, $40 \mathrm{mmol})$ in $\mathrm{CH}_{2} \mathrm{Cl}_{2}(40 \mathrm{~mL})$, and the mixture was stirred at $0-5^{\circ} \mathrm{C}$ for $1 \mathrm{~h}$. The solution was diluted with $\mathrm{CHCl}_{3}$, washed successively with water, $\mathrm{M} \mathrm{HCl}$, and water, and then concentrated. Crude triflate $\mathbf{4 4}$ was dissolved in DMF $(30 \mathrm{~mL})$, sodium azide $(3.25 \mathrm{~g}, 50$ mmol) was added, and the resulting mixture was stirred at $\mathrm{rt}$ overnight. The mixture was diluted with EtOAc, washed thoroughly with water, satd aq $\mathrm{NaCl}$ solution, dried with $\mathrm{MgSO}_{4}$ and concentrated. Column chromatography of the residue (9:1 light petroleum-EtOAc) gave 39 (3.82 g, 93\%): mp 91-92 ${ }^{\circ} \mathrm{C}\left(\mathrm{Et}_{2} \mathrm{O}\right.$-light petroleum $) ;[\alpha]_{\mathrm{D}}-1.3^{\circ}$ (c 1, $\left.\mathrm{CHCl}_{3}\right) .{ }^{1} \mathrm{H}$ NMR: $\delta 1.47$ (d, $3 \mathrm{H}, J_{5,6} 6.1$ $\mathrm{Hz}, \mathrm{H}-6), 3.35$ (t, $\left.1 \mathrm{H}, J_{4,5} 9.7 \mathrm{~Hz}, \mathrm{H}-4\right), 3.44$ $(\mathrm{dq}, 1 \mathrm{H}, \mathrm{H}-5), 3.63\left(\mathrm{dd}, 1 \mathrm{H}, J_{2,3} 10.3 \mathrm{~Hz}\right.$, $\mathrm{H}-2), 4.51\left(\mathrm{~d}, 1 \mathrm{H}, J_{1,2} 8.0 \mathrm{~Hz}, \mathrm{H}-1\right), 4.73,4.97$ $\left(2 \mathrm{~d}, 2 \mathrm{H}, J_{\text {gem }} 11.8 \mathrm{~Hz}, \mathrm{PhCH}_{2}\right), 5.18(\mathrm{t}, 1 \mathrm{H}$, $\left.J_{3,4} 9.8 \mathrm{~Hz}, \mathrm{H}-3\right), 7.33-8.15(\mathrm{~m}, 10 \mathrm{H}, 2 \mathrm{Ph})$. Anal. Calcd for $\mathrm{C}_{20} \mathrm{H}_{20} \mathrm{~N}_{6} \mathrm{O}_{4}: \mathrm{C}, 58.81 ; \mathrm{H}$, 4.94; N, 20.58. Found: C, 58.91; H, 5.06; N, 20.61 .

Benzyl 2,4-diacetamido-2,4,6-trideoxy- $\beta$-Lglucopyranoside (45). - Lithium aluminum hydride $(2.00 \mathrm{~g}, 52.8 \mathrm{mmol})$ was added portionwise at $0{ }^{\circ} \mathrm{C}$ to a stirred solution of 39 (3.59 g, $8.80 \mathrm{mmol})$ in THF $(60 \mathrm{~mL})$. After completion of the exothermic reaction, the mixture was stirred for $1.5 \mathrm{~h}$ at $\mathrm{rt}$. The excess of $\mathrm{LiAlH}_{4}$ was destroyed by careful addition of water, then $5 \mathrm{M} \mathrm{NaOH}$ solution $(150 \mathrm{~mL})$ was added. The organic layer was separated, the aqueous layer was thoroughly extracted with $\mathrm{Et}_{2} \mathrm{O}$. The combined organic solution was dried with $\mathrm{MgSO}_{4}$ and concentrated. The residue in $\mathrm{MeOH}(30 \mathrm{~mL})$ was acetylated with $\mathrm{Ac}_{2} \mathrm{O}(5 \mathrm{~mL})$ overnight at $\mathrm{rt}$. The crystalline precipitate was separated, washed with $\mathrm{MeOH}$, and dried to give $\mathbf{4 5}$ (1.28 g). Column chromatography of the mother liquor (9:1 $\mathrm{CHCl}_{3}-\mathrm{MeOH}$ ) gave an additional portion of the product $(0.72 \mathrm{~g})$. The total yield of $\mathbf{4 5}$ was $2.00 \mathrm{~g}(68 \%): \mathrm{mp} 302-307^{\circ} \mathrm{C}(\mathrm{EtOH}) ;[\alpha]_{\mathrm{D}}$ $+55.1^{\circ}$ (c 1, DMF). ${ }^{1} \mathrm{H}$ NMR $\left(\mathrm{CDCl}_{3}+\right.$ $\left.\mathrm{CD}_{3} \mathrm{OD}\right): \delta 1.11\left(\mathrm{~d}, 3 \mathrm{H}, J_{5,6} 5.8 \mathrm{~Hz}, \mathrm{H}-6\right)$, $1.79,1.83\left(2 \mathrm{~s}, 6 \mathrm{H}, 2 \mathrm{CH}_{3} \mathrm{CO}\right), 3.32(\mathrm{dq}, 1 \mathrm{H}$, H-5), 3.36 (t, $\left.1 \mathrm{H}, J_{4,5} 10.0 \mathrm{~Hz}, \mathrm{H}-4\right), 3.38$ (dd, $\left.1 \mathrm{H}, J_{2,3} 9.7 \mathrm{~Hz}, \mathrm{H}-2\right), 3.49\left(\mathrm{t}, 1 \mathrm{H}, J_{3,4} 9.9 \mathrm{~Hz}\right.$, $\mathrm{H}-3), 4.42,4.71\left(2 \mathrm{~d}, 2 \mathrm{H}, J_{\text {gem }} 12.0 \mathrm{~Hz}\right.$, $\left.\mathrm{PhCH}_{2}\right), 4.42\left(\mathrm{~d}, 1 \mathrm{H}, J_{1,2} 7.5 \mathrm{~Hz}, \mathrm{H}-1\right)$, 7.11-7.19 (m, 5 H, Ph). Anal. Calcd for $\mathrm{C}_{17} \mathrm{H}_{24} \mathrm{~N}_{2} \mathrm{O}_{5}$ : C, 60.70; H, 7.19; N, 8.33. Found: C, 60.60; H, 7.21; N, 8.37.

Benzyl 2,4-diacetamido-2,4,6-trideoxy-3-Omesyl- $\beta$-L-glucopyranoside (46). - Methanesulfonyl chloride $(1.68 \mathrm{~mL}, 21.7 \mathrm{mmol})$ was added at $0{ }^{\circ} \mathrm{C}$ to a suspension of $45(1.82 \mathrm{~g}$, $5.42 \mathrm{mmol})$ in $\mathrm{CH}_{2} \mathrm{Cl}_{2}(30 \mathrm{~mL})$ and py $(10$ $\mathrm{mL}$ ), and the mixture was stirred for $2 \mathrm{~h}$ at $0{ }^{\circ} \mathrm{C}$, then overnight at $\mathrm{rt}$. Water $(100 \mathrm{~mL})$ was added, and the two-phase solution was stirred for $2 \mathrm{~h}$ at $\mathrm{rt}$. The organic layer was separated, the aqueous layer was extracted twice with $\mathrm{CHCl}_{3}$, and the combined organic solution was concentrated to give $0.72 \mathrm{~g}$ of crude 46. The aqueous solution was concentrated to a volume of $\sim 30 \mathrm{~mL}$ and left at $5{ }^{\circ} \mathrm{C}$ overnight. The crystalline precipitate was filtered off and dried to give the second portion of $\mathbf{4 6}$. Both portions of $\mathbf{4 6}$ were combined and subjected to column chromatography (95:5 $\left.\mathrm{CHCl}_{3}-\mathrm{MeOH}\right)$ to yield pure $46(2.16 \mathrm{~g}$, 96\%): $\mathrm{mp} 187-189^{\circ} \mathrm{C}(\mathrm{MeOH}) ;[\alpha]_{\mathrm{D}}+43^{\circ}(c$ 1, DMF). ${ }^{1} \mathrm{H}$ NMR $\left(\mathrm{CDCl}_{3}+\mathrm{CD}_{3} \mathrm{OD}\right): \delta$ $1.15\left(\mathrm{~d}, 3 \mathrm{H}, J_{5,6} 5.7 \mathrm{~Hz}, \mathrm{H}-6\right), 1.78,1.83(2 \mathrm{~s}$, $6 \mathrm{H}, 2 \mathrm{CH}_{3} \mathrm{CO}$ ), 2.84 (s, $\left.3 \mathrm{H}, \mathrm{CH}_{3} \mathrm{SO}_{2}\right), 3.46-$ $3.59(\mathrm{~m}, 3 \mathrm{H}, \mathrm{H}-2,4,5), 4.45,4.73(2 \mathrm{~d}, 2 \mathrm{H}$, $\left.J_{\text {gem }} 12.1 \mathrm{~Hz}, \mathrm{PhCH}_{2}\right), 4.64\left(\mathrm{~d}, 1 \mathrm{H}, J_{1,2} 8.3\right.$ $\mathrm{Hz}, \mathrm{H}-1), 4.85\left(\mathrm{t}, 1 \mathrm{H}, J_{2,3} \sim J_{3,4} \sim 9.8 \mathrm{~Hz}\right.$, $\mathrm{H}-3), 7.13-7.21(\mathrm{~m}, 5 \mathrm{H}, \mathrm{Ph})$. Anal. Calcd for $\mathrm{C}_{18} \mathrm{H}_{26} \mathrm{~N}_{2} \mathrm{O}_{5} \mathrm{~S}: \mathrm{C}, 52.16 ; \mathrm{H}, 6.32 ; \mathrm{N}, 6.76$. Found: C, 52.13; H, 6.46; N, 6.47.

Benzyl 2,4-diacetamido-2,4,6-trideoxy- $\beta$-Lallopyranoside (47). - A mixture of $46(2.10 \mathrm{~g}$, 
$5.07 \mathrm{mmol}$ ) and AcONa (2.08 g, $25.4 \mathrm{mmol})$ in $95 \%$ aq 2 -methoxyethanol $(50 \mathrm{~mL})$ was boiled under reflux for $2.5 \mathrm{~h}$. The solvent was evaporated and a suspension of the residue in 85:15 $\mathrm{CHCl}_{3}-\mathrm{MeOH}$ was filtered through a layer of silica gel. The filtrate was concentrated, and the residue was chromatographed (92:8 $\left.\mathrm{CHCl}_{3}-\mathrm{MeOH}\right)$ to give $47(1.62 \mathrm{~g}, 95 \%)$ : $\mathrm{mp} 301-305^{\circ} \mathrm{C}\left(\mathrm{EtOH}-\mathrm{Et}_{2} \mathrm{O}\right) ;[\alpha]_{\mathrm{D}}+47.6^{\circ}$ (c 1, DMF). ${ }^{1} \mathrm{H}$ NMR $\left(\mathrm{C}_{6} \mathrm{D}_{6}+\mathrm{CD}_{3} \mathrm{OD}\right): \delta$ $1.28\left(\mathrm{~d}, 3 \mathrm{H}, J_{5,6} 5.8 \mathrm{~Hz}, \mathrm{H}-6\right), 1.83,1.84(2 \mathrm{~s}$, $\left.6 \mathrm{H}, 2 \mathrm{CH}_{3} \mathrm{CO}\right), 3.92$ (dq, $\left.1 \mathrm{H}, \mathrm{H}-5\right), 3.97$ (dd, $\left.1 \mathrm{H}, J_{4,5} 10.2 \mathrm{~Hz}, \mathrm{H}-4\right), 4.02\left(\mathrm{t}, 1 \mathrm{H}, J_{3,4} 2.3\right.$ $\mathrm{Hz}, \mathrm{H}-3$ ), 4.16 (dd, $1 \mathrm{H}, J_{2,3} 2.8 \mathrm{~Hz}, \stackrel{\mathrm{H}-2}{ }$ ), 4.51, $4.82\left(2 \mathrm{~d}, 2 \mathrm{H}, J_{\mathrm{gem}} 12.0 \mathrm{~Hz}, \mathrm{PhCH}_{2}\right)$, $4.87\left(\mathrm{~d}, 1 \mathrm{H}, J_{1,2} 8.6 \mathrm{~Hz}, \mathrm{H}-1\right), 7.08-7.28(\mathrm{~m}$, $5 \mathrm{H}, \mathrm{Ph})$. Anal. Calcd for $\mathrm{C}_{17} \mathrm{H}_{24} \mathrm{~N}_{2} \mathrm{O}_{5}: \mathrm{C}$, 60.70; H, 7.19; N, 8.33. Found: C, 60.53; H, 7.13; N, 8.29.

2,4-Diacetamido-2,4,6-trideoxy-L-allopyranose (48). - $20 \% \quad \mathrm{Pd}(\mathrm{OH})_{2} / \mathrm{C} \quad(500 \mathrm{mg})$ was added to a solution of $47(1.40 \mathrm{~g}, 4.17 \mathrm{mmol})$ in $\mathrm{MeOH}(50 \mathrm{~mL})$, (Caution: Extreme fire hazard), and the mixture was stirred under hydrogen at $35^{\circ} \mathrm{C}$ for $1 \mathrm{~h}$. Water $(10 \mathrm{~mL})$ was added until complete dissolution of a white precipitate and formation of a clear solution over the catalyst, then hydrogenolysis was continued for another $1 \mathrm{~h}$. The catalyst was filtered off through Celite, and washed with $80 \%$ aq $\mathrm{MeOH}$, and the combined filtrate and washings were concentrated. Crystallization from water $-\mathrm{EtOH}-\mathrm{Et}_{2} \mathrm{O}$ gave $48(890 \mathrm{mg}$, $87 \%): \operatorname{mp~} 235-242{ }^{\circ} \mathrm{C} ;[\alpha]_{\mathrm{D}}-3.5^{\circ} \rightarrow-15.7^{\circ}$ (c 1, water). ${ }^{1} \mathrm{H}$ NMR ( $\left.\mathrm{D}_{2} \mathrm{O}\right): \mathbf{4 8} \alpha, \delta 1.20(\mathrm{~d}, 3$ $\left.\mathrm{H}, J_{5,6} 6.2 \mathrm{~Hz}, \mathrm{H}-6\right), 2.04,2.06(2 \mathrm{~s}, 6 \mathrm{H}, 2$ $\mathrm{CH}_{3} \mathrm{CO}$ ), 3.79 (dd, $\left.1 \mathrm{H}, J_{4,5} 10.6 \mathrm{~Hz}, \mathrm{H}-4\right)$, $3.96\left(\mathrm{t}, 1 \mathrm{H}, J_{3,4} 2.8 \mathrm{~Hz}, \mathrm{H}-3\right), 4.05\left(\mathrm{t}, 1 \mathrm{H}, J_{2,3}\right.$ $3.3 \mathrm{~Hz}, \mathrm{H}-2), 4.18$ (dq, $1 \mathrm{H}, \mathrm{H}-5), 5.15$ (d, 1 $\left.\mathrm{H}, J_{1,2} 3.8 \mathrm{~Hz}, \mathrm{H}-1\right)$. 48及, $\delta 1.20\left(\mathrm{~d}, 3 \mathrm{H}, J_{5,6}\right.$ 6.2 Hz, H-6), 2.03, $2.04\left(2 \mathrm{~s}, 6 \mathrm{H}, 2 \mathrm{CH}_{3} \mathrm{CO}\right)$, 3.76 (dd, $\left.1 \mathrm{H}, J_{4,5} 10.4 \mathrm{~Hz}, \mathrm{H}-4\right), 3.81$ (dd, 1 H, $\left.J_{2,3} 2.9 \mathrm{~Hz}, \mathrm{H}-2\right), 3.92$ (dq, $\left.1 \mathrm{H}, \mathrm{H}-5\right), 3.97$ $\left(\mathrm{t}, 1 \mathrm{H}, J_{3,4} 2.9 \mathrm{~Hz}, \mathrm{H}-3\right), 4.94\left(\mathrm{~d}, 1 \mathrm{H}, J_{1,2} 8.8\right.$ $\mathrm{Hz}, \mathrm{H}-1)$. The ratio $\mathbf{4 8} \alpha: \mathbf{4 8 \beta} \approx 1: 3.3$. Anal. Calcd for $\mathrm{C}_{10} \mathrm{H}_{18} \mathrm{~N}_{2} \mathrm{O}_{5}: \mathrm{C}, 48.77 ; \mathrm{H}, 7.37 ; \mathrm{N}$, 11.38. Found: C, 48.76; H, 7.41; N, 11.40 .

5,7-Diacetamido-3,5,7,9-tetradeoxy-L-glycero-D-galacto- and L-glycero-D-talo-non-2ulosonic acids (49 and 50).-Oxalacetic acid (165 mg, $1.25 \mathrm{mmol}$ ) was dissolved in water (4
$\mathrm{mL}$ ), and the $\mathrm{pH}$ of the solution was adjusted to 10.5 by adding $5 \mathrm{M} \mathrm{NaOH}$ solution. Sodium tetraborate decahydrate $(190 \mathrm{mg}, 0.5$ $\mathrm{mmol}$ ) was added, and the $\mathrm{pH}$ was adjusted to 10.5 again. Then solid 15 (308 mg, $1.25 \mathrm{mmol})$ was added, and the resulting mixture was stirred at $\mathrm{rt}$ while the $\mathrm{pH}$ was maintained at 10.5 as above. More oxalacetic acid (42 mg, $0.31 \mathrm{mmol}$ ) was added after 6,24 , and $48 \mathrm{~h}$. After being stirred for $72 \mathrm{~h}$, the mixture was neutralized with Amberlite $420\left(\mathrm{H}^{+}\right)$, and filtered, and the filtrate was concentrated to a volume of 3-4 mL. The solution was applied to a column of Dowex $1 \times 8\left(\mathrm{HCOO}^{-}\right)$, and the column was washed first with water to elute neutral products, then with $0.3 \mathrm{M}$ formic acid. The appropriate fractions were pooled and concentrated, and the residue was subjected to preparative reversed-phase $\mathrm{C}_{18}$ HPLC to give $49(75 \mathrm{mg}, 18 \%), t_{\mathrm{R}} 9.2 \mathrm{~min}$, and 50 (84 mg, 20\%), $t_{\mathrm{R}} 10.5 \mathrm{~min}$, as amorphous solids. Acid 49 had $[\alpha]_{\mathrm{D}}+15.4^{\circ}(c$ 1.6, water). $\operatorname{ESIMS}(+)$ : Calcd for $[\mathrm{M}+\mathrm{Na}]^{+}$ 357.1. Found 356.8. Compound 50 had $[\alpha]_{\mathrm{D}}$ $-19.2^{\circ}$ (c 1.6, water). ESIMS ( + ): Calcd for $[\mathrm{M}+\mathrm{Na}]^{+}$357.1. Found 356.8. For ${ }^{1} \mathrm{H}$ and ${ }^{13} \mathrm{C}$ NMR data for 49 and 50, see Tables 2 and 3.

5,7-Diacetamido-3,5,7,9-tetradeoxy-D-glycero-L-altro- and D-glycero-L-manno-non-2ulosonic acids (51 and 52).-Hexose 25 (150 $\mathrm{mg}, 0.61 \mathrm{mmol})$ was allowed to react with oxalacetic acid in the presence of sodium tetraborate as described for 15. Anion-exchange chromatography and reversed-phase HPLC of the condensation products afforded $\mathbf{5 2}(8 \mathrm{mg}$, $4 \%), t_{\mathrm{R}} 8.5 \mathrm{~min},[\alpha]_{\mathrm{D}}-39.0^{\circ}$ (c 0.5 , water $)$, and $51(57 \mathrm{mg}, 28 \%), t_{\mathrm{R}} 14.6 \mathrm{~min},[\alpha]_{\mathrm{D}}-$ $14.3^{\circ}$ ( $c$ 1, water). ESIMS $(+)$ : Calcd for $[\mathrm{M}+\mathrm{Na}]^{+}$357.1. Found 357.0 for both $\mathbf{5 1}$ and 52. For ${ }^{1} \mathrm{H}$ and ${ }^{13} \mathrm{C}$ NMR data see Tables 2 and 3 .

5,7-Diacetamido-3,5,7,9-tetradeoxy-D-glycero-D-galacto- and D-glycero-D-talo-non-2ulosonic acids (53 and 54).-Condensation of $32(375 \mathrm{mg}, 1.52 \mathrm{mmol})$ with oxalacetic acid was performed as described for 15. After anion-exchange chromatography and reversedphase HPLC, compounds 53 (36 mg, 7\%), $t_{\mathrm{R}}$ $11.2 \mathrm{~min},[\alpha]_{\mathrm{D}}+27.2^{\circ}$ (c 1, water), and $\mathbf{5 4}(50$ $\mathrm{mg}, 10 \%), t_{\mathrm{R}} 13.0 \min ,[\alpha]_{\mathrm{D}}-12.5^{\circ}(c 1$, water), were obtained. ESIMS ( -$)$ : Calcd for 
$[\mathrm{M}-\mathrm{H}]^{-}$333.1. Found 332.9 for 53 and 333.1 for 54. For ${ }^{1} \mathrm{H}$ and ${ }^{13} \mathrm{C}$ NMR data, see Tables 2 and 3.

\section{5,7-Diacetamido-3,5,7,9-tetradeoxy-L-glyc-} ero-L-altro-, L-glycero-L-manno-, and L-glycero-L-gluco-non-2-ulosonic acids $(\mathbf{5 5}, \mathbf{5 6}$, and 57). - Reaction of 48 (308 $\mathrm{mg}, 1.25 \mathrm{mmol})$ with oxalacetic acid, followed by anion-exchange chromatography and reversed-phase HPLC, afforded $56(12 \mathrm{mg}, 3 \%), t_{\mathrm{R}} 8.5 \mathrm{~min}$, $[\alpha]_{\mathrm{D}}-56.9^{\circ}$ (c 1, water), 57 (5 mg, 1\%), $t_{\mathrm{R}}$ $12.5 \mathrm{~min},[\alpha]_{\mathrm{D}}-76.0^{\circ}$ (c 0.5, water), and $\mathbf{5 5}$ $(34 \mathrm{mg}, 8 \%), t_{\mathrm{R}} 13.3 \mathrm{~min},[\alpha]_{\mathrm{D}}-48.2^{\circ}(c 1$, water). ESIMS $(-)$ : Calcd for $[\mathrm{M}-\mathrm{H}]^{-}$ 333.1. Found 333.4 for $\mathbf{5 5}$ and 333.3 for both 56 and 57. For ${ }^{1} \mathrm{H}$ and ${ }^{13} \mathrm{C}$ NMR data see Tables 2 and 3.

Methyl (5,7-diacetamido-2,4,8-tri-O-acetyl3,5,7,9 - tetradeoxynon - 2 - ulopyranos)onates (62-65). - Etheral diazomethane was added to solutions of acids $\mathbf{4 9}, \mathbf{5 1}, \mathbf{5 3}$, and $\mathbf{5 5}(15-20$ $\mathrm{mg}$ of each) in $\mathrm{MeOH}(0.5-0.7 \mathrm{~mL})$ until a yellow colour in the solutions persisted. A drop of $\mathrm{AcOH}$ was added, and the mixtures were taken to dryness. The residues were subjected to reversed-phase $\mathrm{C}_{18}$ HPLC in aq $\mathrm{MeOH}(6-8 \%)$ to give esters 58-61 as amorphous solids.

Compound 58: yield 52\%; $[\alpha]_{\mathrm{D}}+26.0^{\circ}(c 1$, water). ${ }^{1} \mathrm{H}$ NMR: $\delta 1.15\left(\mathrm{~d}, 3 \mathrm{H}, J_{8,9} 6.3 \mathrm{~Hz}\right.$, H-9), 1.89 (dd, $\left.1 \mathrm{H}, J_{3 \mathrm{ax}, 4} 11.5 \mathrm{~Hz}, \mathrm{H}-3 \mathrm{ax}\right)$, 1.98, $2.00\left(2 \mathrm{~s}, 6 \mathrm{H}, 2 \mathrm{CH}_{3} \mathrm{CO}\right), 2.30(\mathrm{dd}, 1 \mathrm{H}$, $\left.J_{3 \text { eq, } 4} 4.9 \mathrm{~Hz}, J_{3 \text { ax }, 3 \text { eq }} 13.1 \mathrm{~Hz}, \mathrm{H}-3 \mathrm{eq}\right), 3.71$ (t, 1 $\left.\mathrm{H}, J_{5.6} 10.5 \mathrm{~Hz}, \mathrm{H}-5\right), 3.83$ (dq, $\left.1 \mathrm{H}, \mathrm{H}-8\right), 3.86$ $\left(\mathrm{s}, 3 \mathrm{H}, \mathrm{CH}_{3} \mathrm{O}\right), 3.91\left(\mathrm{dd}, 1 \mathrm{H}, J_{7.8} 8.8 \mathrm{~Hz}\right.$, H-7), 3.97 (ddd, $\left.1 \mathrm{H}, J_{4,5} 10.2 \mathrm{~Hz}, \mathrm{H}-4\right), 4.32$ (dd, $1 \mathrm{H}, J_{6,7} 2.1 \mathrm{~Hz}, \mathrm{H}-6$ ).

Compound 59: yield $35 \% ;[\alpha]_{\mathrm{D}}-27.7^{\circ}(c$ 0.4, water). ${ }^{1} \mathrm{H}$ NMR: $\delta 1.09$ (d, $3 \mathrm{H}, J_{8,9} 6.4$ $\mathrm{Hz}, \mathrm{H}-9$ ), 1.93 (dd, $1 \mathrm{H}, J_{3 \mathrm{ax}, 4} 11.6 \mathrm{~Hz}, \mathrm{H}-3 \mathrm{ax}$ ), 2.05, $2.06\left(2 \mathrm{~s}, 6 \mathrm{H}, 2 \mathrm{CH}_{3} \mathrm{CO}\right), 2.34(\mathrm{dd}, 1 \mathrm{H}$, $J_{3 \text { eq, } 4} 4.7 \mathrm{~Hz}, J_{3 \text { eq, 3ax }} 13.2 \mathrm{~Hz}, \mathrm{H}-3 \mathrm{eq}$ ), 3.84 (s, 3 $\left.\mathrm{H}, \mathrm{CH}_{3} \mathrm{O}\right), 3.85\left(\mathrm{t}, 1 \mathrm{H}, J_{5,6} 10.3 \mathrm{~Hz}, \mathrm{H}-5\right)$, $3.92\left(\mathrm{dd}, 1 \mathrm{H}, J_{6,7} 3.0 \mathrm{~Hz}, \mathrm{H}-6\right), 3.93(\mathrm{~d}, 1 \mathrm{H}$, H-7), 3.99 (ddd, $\left.1 \mathrm{H}, J_{4,5} 11.3 \mathrm{~Hz}, \mathrm{H}-4\right), 4.39$ (q, $1 \mathrm{H}, \mathrm{H}-8$ ).

Compound 60: yield $57 \% ;[\alpha]_{\mathrm{D}}+33.5^{\circ}(c 1$, water). ${ }^{1} \mathrm{H}$ NMR: $\delta 1.15\left(\mathrm{~d}, 3 \mathrm{H}, J_{8,9} 6.3 \mathrm{~Hz}\right.$, H-9), 1.89 (dd, $\left.1 \mathrm{H}, J_{3 \mathrm{ax}, 4} 11.5 \mathrm{~Hz}, \mathrm{H}-3 \mathrm{ax}\right)$, 1.98, $2.00\left(2 \mathrm{~s}, 6 \mathrm{H}, 2 \mathrm{CH}_{3} \mathrm{CO}\right), 2.30(\mathrm{dd}, 1 \mathrm{H}$, $\left.J_{3 \text { eq, } 4} 4.9 \mathrm{~Hz}, J_{3 \text { eq, 3ax }} 13.1 \mathrm{~Hz}, \mathrm{H}-3 \mathrm{eq}\right), 3.71$ (t, 1
$\left.\mathrm{H}, J_{5,6} 10.5 \mathrm{~Hz}, \mathrm{H}-5\right), 3.83$ (dq, $\left.1 \mathrm{H}, \mathrm{H}-8\right), 3.86$ $\left(\mathrm{s}, 3 \mathrm{H}, \mathrm{CH}_{3} \mathrm{O}\right), 3.91\left(\mathrm{dd}, 1 \mathrm{H}, J_{7.8} 8.8 \mathrm{~Hz}\right.$, H-7), 3.97 (ddd, $\left.1 \mathrm{H}, J_{4,5} 10.2 \mathrm{~Hz}, \mathrm{H}-4\right), 4.32$ (dd, $\left.1 \mathrm{H}, J_{6,7} 2.1 \mathrm{~Hz}, \mathrm{H}-6\right)$.

Compound 61: yield $49 \% ;[\alpha]_{\mathrm{D}}-55.1^{\circ}(c 1$, water). ${ }^{1} \mathrm{H}$ NMR: $\delta 1.18\left(\mathrm{~d}, 3 \mathrm{H}, J_{8,9} 6.4 \mathrm{~Hz}\right.$, H-9), 1.94 (dd, $\left.1 \mathrm{H}, J_{3 a x, 4} 11.2 \mathrm{~Hz}, \mathrm{H}-3 \mathrm{ax}\right)$, 2.03, $2.07\left(2 \mathrm{~s}, 6 \mathrm{H}, 2 \mathrm{CH}_{3} \mathrm{CO}\right), 2.30(\mathrm{dd}, 1 \mathrm{H}$, $\left.J_{3 \text { eq, } 4} 4.6 \mathrm{~Hz}, J_{3 \text { eq, 3ax }} 13.2 \mathrm{~Hz}, \mathrm{H}-3 \mathrm{eq}\right), 3.84$ (s, 3 $\left.\mathrm{H}, \mathrm{CH}_{3} \mathrm{O}\right), 3.88\left(\mathrm{t}, 1 \mathrm{H}, J_{5,6} 10.4 \mathrm{~Hz}, \mathrm{H}-5\right)$, 3.94 (ddd, $\left.1 \mathrm{H}, J_{4,5} 11.1 \mathrm{~Hz}, \mathrm{H}-4\right), 3.95$ (dd, 1 $\mathrm{H}, J_{6,7} 3.2 \mathrm{~Hz}, \mathrm{H}-6$ ), 4.04 (quintet, $1 \mathrm{H}, \mathrm{H}-8$ ), $4.15\left(\mathrm{dd}, 1 \mathrm{H}, J_{7.8} 5.7 \mathrm{~Hz}, \mathrm{H}-7\right)$.

Esters 58-61 (5-10 mg of each) were acetylated with $\mathrm{Ac}_{2} \mathrm{O}(0.2 \mathrm{~mL})$ in py $(0.4 \mathrm{~mL})$ for $48 \mathrm{~h}$ at rt. After concentration and removal of residual $\mathrm{Ac}_{2} \mathrm{O}$ and py by coevaporation with toluene, the residues were passed through a Sep Pak Silica cartridge in 96:4 $\mathrm{CHCl}_{3}-$ $\mathrm{MeOH}$ and the eluates were concentrated to give acetates 62-65, respectively. For ${ }^{1} \mathrm{H}$ and ${ }^{13} \mathrm{C}$ NMR data, see Table 4.

\section{Acknowledgements}

This work was supported by grant 436 RUS $113 / 314 / 0$ of the Deutsche Forschungsgemeinschaft and grants 99-03-32955 and 00-0404009 of the Russian Foundation for Basic Research. The authors thank Prof. L.V. Backinowsky for critical reading of the manuscript.

\section{References}

1. Knirel, Y. A.; Kochetkov, N. K. FEMS Microbiol. Rev. 1987, 46, 381-384.

2. Knirel, Y. A.; Kochetkov, N. K. Biochemistry (Moscow) 1994, 59, 1325-1383.

3. Zähringer, U.; Knirel, Y. A.; Lindner, B.; Helbig, J. H.; Sonesson, A.; Marre, R.; Rietschel, E. T. In Bacterial Endotoxins Lipopolysaccharides from Genes to Therapy; Levin, J.; Alving, C. R.; Munford, R. S.; Redl, H., Eds.; Wiley-Liss: New York, 1995; pp. 113-139.

4. Gil-Serrano, A. M.; Rodríguez-Carvajal, M. A.; TejeroMateo, P.; Espartero, J. L.; Menendez, M.; Corzo, J.; Ruiz-Sainz, J. E.; Buendía-Clavería, A. M. Biochem. J. 1999, 342, 527-535.

5. Castric, P.; Cassels, F. J.; Carlson, R. W. J. Biol. Chem. 2001, 276, 26479-26485.

6. Thibault, P; Logan, S. M.; Kelly, J. F.; Brisson, J.-R.; Ewing, C. P.; Trust, T. J.; Guerry, P. J. Biol. Chem. 2001, in press.

7. Tsvetkov, Y. E.; Shashkov, A. S.; Knirel, Y. A.; Backinowsky, L. V.; Zähringer, U. Mendeleev Commun. 2000, 90-92. 
8. Tsvetkov, Y. E.; Shashkov, A. S.; Knirel, Y. A.; Zähringer, U. Carbohydr. Res. 2001, 331, 233-237.

9. How, M. J.; Halford, M. D. A.; Stacy, M.; Vickers, E. Carbohydr. Res. 1969, 11, 313-320.

10. Karpiesiuk, W.; Banaszek, A.; Zamojski, A. Carbohydr. Res. 1989, 186, 156-162.

11. Kochetkov, N. K.; Byramova, N. E.; Tsvetkov, Y. E.; Backinowsky, L. V. Tetrahedron 1986, 41, 3363-3375.

12. Srivastava, V. K.; Schuerch, C. Tetrahedron Lett. 1979, 35, 3269-3272.

13. Tsvetkov, Y. E.; Backinowsky, L. V.; Kochetkov, N. K. Carbohydr. Res. 1989, 193, 75-90.

14. Buchanan, J. G.; Schwarz, J. C. P J. Chem. Soc. 1962, 4770-4777.

15. Ali, Y.; Richardson, A. C. Carbohydr. Res. 1967, 5, 441-448.

16. Meyer zu Reckendorf, W. Chem. Ber. 1969, 102, 42074208.

17. Auge, C.; David, S.; Gautheron, C.; Malleron, A.; Cavaye, B. New J. Chem. 1988, 12, 733-744.

18. Kochetkov, N. K.; Dmitriev, B. A.; Byramova, N. E.; Nikolaev, A. V. Izv. Akad. Nauk SSSR. Ser. Khim. 1978 652-656.

19. Capon, B. Chem. Rev. 1969, 69, 407-498.

20. Ipaktschi, J. Chem. Ber. 1984, 117, 856-858.
21. Capek, K.; Capkova, J.; Jary, J.; Knirel, Y. A. Collect. Czech. Chem. Commun. 1987, 52, 2248-2259.

22. Breitmeier, E.; Voelter, W. Carbon-13 NMR Spectroscopy; VCH: Weinheim, 1990; pp. 381-384.

23. Mikhailov, S. N.; Padyukova, N. S.; Struchkova, M. I.; Yarotsky, S. V. Bioorg. Khim. 1982, 8, 926-932.

24. Paulsen, H.; Todt, K. Adv. Carbohydr. Chem. 1968, 23, $115-232$.

25. Flowers, H. M.; Levy, A.; Sharon, N. Carbohydr. Res. 1967, 4, 189-195.

26. David, S.; Fernandez-Mayoralas, A. Carbohydr. Res. 1987, 165, C11-C13.

27. Eis, M. J.; Ganem, B. Carbohydr. Res. 1988, 176, 316323.

28. Bundle, D. R.; Gerken, M.; Peters, T. Carbohydr. Res. 1988, 174, 239-251.

29. Knirel, Y. A.; Kocharova, N. A.; Shashkov, A. S.; Kochetkov, N. K. Carbohydr. Res. 1986, 145, C1-C4.

30. Pritulla, S.; Lauterwein, J.; Klessinger, M.; Thiem, J. Carbohydr. Res. 1991, 215, 345-349.

31. Pritulla, S.; Lambert, J.; Lauterwein, J.; Klessinger, M.; Thiem, J. Magn. Reson. Chem. 1990, 28, 888-901.

32. Matsumori, N.; Kaneno, D.; Murata, M.; Nakamura, H.; Tashibana, K. J. Org. Chem. 1999, 64, 866-876. 